REVISTA DE DERECHO UNED, NÚM. 23, 2018

\title{
LA CADUCIDAD EN LA INICIACIÓN DEL PROCEDIMIENTO SANCIONADOR TRIBUTARIO
}

\author{
THE EXPIRATION IN THE INITIATION \\ OF THE PENALIZING TAX PROCEDURE
}

\section{IVÁN PÉREZ JORDÁ}

Funcionario de Administración Local con habilitación de carácter nacional. Doctor en Derecho Financiero y Tributario. Profesor Asociado de Derecho Administrativo en la Universidad de Valencia. Licenciado en Ciencias Políticas. Doctorando en Filosofía y Letras en la UNED

Resumen: El presente artículo se analiza detenidamente la caducidad en la incoación del procedimiento sancionador tributario como causa obstativa a la declaración de la responsabilidad infractora.

Palabras clave: Caducidad, interrupción de la caducidad, procedimiento sancionador tributario, prescripción.

Abstract: This paper analyses expiration in the initiation of the penalizing tax procedure as a circumstance which precludes penalizing liabilities.

Keywords: Expiration, suspension of expiration, penalizing tax procedure, statute of limitations.

Recepción original: 02/03/2018

Aceptación original: 05/07/2018

Sumario: I. La caducidad en el procedimiento sancionador tributario. I.1. Acepción. I.2. Objeto. I.3. Naturaleza jurídica. I.4. Fundamento.-II. Elementos de la caducidad. II.1. Inactividad del órgano competente sancionador tributario. II.2. Tipos de procedimien- 
tos tributarios susceptibles de caducidad sancionadora tributaria. II.3. Transcurso del plazo. a) Fundamento del límite temporal de la caducidad sancionadora tributaria. b) Dies a quo de la caducidad sancionadora tributaria. c) Relación entre caducidad sancionadora tributaria y prescripción de la infracción tributaria. d) Caducidad en la terminación del procedimiento sancionador tributario.-III. Caducidad en la iniciación del procedimiento sancionador tributario. III.1. Naturaleza jurídica. III.2. Acuerdo incoatorio del procedimiento sancionador tributario. III.3. Notificación del acuerdo incoatorio del procedimiento sancionador tributario. III.4. Órgano incoador del procedimiento sancionador tributario. III.5. Tipos de formas de terminación de los procedimientos de aplicación de los tributos de los que trae causa la caducidad en la iniciación del procedimiento sancionador tributario. III.6. Intervención en el procedimiento sancionador tributario del responsable tributario en el pago de la sanción tributaria. III.7. Limitación temporal para la adopción del acuerdo incoatorio del procedimiento sancionador tributario. III.8. Justificación de la limitación temporal para la adopción del acuerdo incoatorio del procedimiento sancionador tributario. III.9. Procedimientos que pueden ser objeto de caducidad en la incoación de procedimiento sancionador tributario. III.10. Caducidad en la incoación de procedimiento sancionador tributario y prescripción de la infracción tributaria.-IV. Inexistencia de interrupción del plazo de caducidad. IV.1. Modo de notificación de la terminación del procedimiento sancionador tributario.--V. Efectos de la caducidad.-VI. Conclusiones.

\section{LA CADUCIDAD EN EL PROCEDIMIENTO SANCIONADOR TRIBUTARIO}

\section{I.1. Acepción ${ }^{1}$}

Debemos entender la caducidad como aquella institución jurídica que sirve y protege la seguridad jurídica ante la existencia de un procedimiento pendiente o de un derecho potestativo de los que se deriva

\footnotetext{
${ }^{1}$ Este procedimiento sancionador tributario comprende todas aquellas actuaciones administrativas que posibilitan el ejercicio de la potestad sancionadora permitiendo detectar comportamientos antijurídicos de los obligados tributarios, calificarlos en función de los diferentes tipos de infracciones establecidas legalmente y determinar la sanción proporcionada con los ilícitos previamente calificados. ESEVERRI MARTÍNEZ, E.: Derecho Tributario. Parte General, Tirant lo Blanch, Valencia, 2011, pág. 461.
} 
una situación jurídica de pendencia de una persona que se supedita a las resultas de la voluntad de otra ${ }^{2}$. La caducidad es, en último término, un instrumento que incentiva el cumplimiento de los plazos y la diligencia de la Administración en resolver los procedimientos en los plazos señalados, si bien no es el único método para ello. No obstante, debe señalarse que esa aptitud de la caducidad opera como una especie de sanción para aquellos funcionarios que incumplan el plazo de resolución, obligándoles a archivar las actuaciones ${ }^{3}$.

\section{I.2. Objeto}

El objeto de la caducidad, en general, es poner limite al ejercicio de las potestades administrativas ${ }^{4}$, si bien esta dialéctica puede

${ }^{2}$ Definición de BAYONA GIMÉNEZ, J.J.: La caducidad en el Ordenamiento tributario español, Aranzadi, Navarra, 1999, pág. 76. Frente a ello la prescripción protege la seguridad jurídica del menoscabo que conlleva el no ejercicio de un derecho durante un dilatado período de tiempo, con la fundada presunción de abandono que al mismo se liga.

${ }^{3}$ Esa caducidad-sanción ha sido precisada por CABALLERO SÁNCHEZ, R.: Prescripción y caducidad en el ordenamiento administrativo, McGraw-Hill, Madrid, 1999, págs. 145 a 148.

${ }^{4}$ Por el contrario, para DE JUAN CASADEVALL la caducidad se refiere al derecho, o más precisamente a la acción, mientras que la perención es un instituto eminentemente procesal, muy próximo a lo que nuestra doctrina procesalista clásica, y la propia LECiv, califican como caducidad de la instancia 2. La perención extingue el procedimiento por inactividad procesal, pero no el derecho que le sirve de base. La caducidad, o decadencia del derecho, es la extinción del derecho temporal cuyo ejercicio aparece indisociablemente vinculado, desde su nacimiento, a un plazo legal o convencionalmente preestablecido 3. Ésa es precisamente la diferencia fundamental con la prescripción extintiva, en la que el derecho nace libre de toda atadura temporal, que sólo aparece ex post, cuando su no ejercicio durante el plazo fijado por la ley conmina a su extinción, bien por exigencias de seguridad jurídica (tesis objetiva), bien por una presunción de abandono de su titular (tesis subjetiva). El efecto práctico de esta distinción teórica es que la prescripción extintiva, que debe ser alegada, es susceptible de interrupción reiniciándose el plazo prescripción, mientras que la caducidad, apreciable de oficio, no puede interrumpirse. Pues bien, si la prescripción y la caducidad, suponen la muerte del derecho o de la acción por su no ejercicio, o por la expiración del plazo fatal establecido ex lege, la perención supone la muerte del procedimiento por inactividad de las partes que, como óbice procesal, no excluye el reinicio del mismo, siempre que no haya prescrito el derecho o caducado la acción. Por ende, desde un punto de vista descriptivo-funcional, podemos definir la perención como la forma de terminación anormal del procedimiento, determinante de su extinción, que, sin prejuzgar la prescripción del derecho y/o la caducidad de la acción, se produce por el vencimiento del plazo máximo de duración sin haberse notificado su resolución, o por su paralización o interrupción injustificada, imputable al administrado, durante el tiempo preestablecido por la Ley. DE JUAN CASADEVALL, J.: «La caducidad (perención) de los procedimientos tributarios en la nueva LGT», QF, núm. 12, 2005. 
ser superada considerando que lo que caduca son las facultades jurídicas que, como parcelas de un poder concreto, forman parte de la potestad. Sin embargo, en el ejercicio de la potestad sancionadora, y también en la tributaria, no nos encontramos ante una situación claudicante o en la que el ordenamiento requiera que se aclare la situación para que se produzcan unas situaciones jurídicas firmes e inatacables, sino que se trata de sancionar unas conductas dentro de un plazo razonable, y no en la configuración o modificación de una situación jurídica, por ello Aguado y Cudolá ${ }^{5}$ admite que en el ámbito sancionador administrativo la caducidad se refiere al procedimiento en que las sanciones se formalizan, estimando que los casos de caducidad de la acción son en realidad supuestos de prescripción especial cuyo plazo se fija de modo diferente y temporalmente con plazo más corto.

\section{I.3. Naturaleza jurídica}

Según algunos autores ${ }^{6}$ existe incompatibilidad entre el instituto jurídico de la caducidad con el ejercicio por parte de la Administración de su potestad sancionadora, lo que les lleva a negar que, en la esfera jurídica de la imposición de sanciones administrativas, pueda coexistir, junto a la sedicente prescripción de la infracción administrativa y la caducidad -en la terminación- del procedimiento administrativo sancionador, la caducidad de la potestad de la Administración para perseguir y sancionar las infracciones administrativas.

Desde otro punto de vista ${ }^{7}$ se defiende que el plazo de tres meses del artículo 209 de la LGT es un plazo de caducidad, en el sentido estricto del término, es decir, con efectos preclusivos, de modo que si el procedimiento no se inicia dentro de ese plazo, ya no podrá incoarse respecto de la persona o entidad que hubiese sido objeto del procedimiento de aplicación del que trae causa el sancionador.

5 AGUADO I CUDOLÀ, V.: Prescripción y caducidad en el ejercicio de potestades administrativas, Marcial Pons, Madrid, 1999, págs. 25, 152 y 153.

${ }^{6}$ Constituyen los principales exponentes de la tesis de la inviabilidad de sujetar a plazos de caducidad la actuación de la potestad sancionadora de la Administración, REBOLLO PUIG, M.: Potestad Sancionadora, alimentación y salud pública, INAP, Madrid, 1989, págs. 792 a 794, GARBERÍ LLOBREGAT, J. (dir.) et alii: El procedimiento administrativo sancionador, Tirant lo Blanch,Valencia, 1998, págs. 162 y ss.; AGUADO I CUDOLÀ, V.: Prescripción..., op. cit., págs. 24 y ss.; y HERNÁNDEZ GONZÁLEZ, F.: La caducidad del procedimiento administrativo, Montecorvo, Madrid, 1998, págs. 261 y 262.

7 PÉREZ ROYO,F.: Derecho Financiero y Tributario. Parte General, Civitas, Madrid, 2009, pág. 427. 
Otro sector ${ }^{8}$ estima que si bien, para la generalidad de la doctrina, el plazo de incoación de tres meses desde que se hubiere notificado la correspondiente liquidación tributaria, se caracteriza como de caducidad, para este autor se acerca más al de un plazo perentorio o de preclusión de un trámite esencial para el inicio de este procedimiento. Lo justifica en que el artículo 104 LGT regula la caducidad tributaria como una forma de dar por terminado un procedimiento tributario sin que haya mediado resolución expresa del mismo por el transcurso del plazo máximo para dictarla establecido en la ley. Así ese no sería el caso que determina el plazo ordenado en el artículo 209.2 LGT, que marca un lapso temporal para que el órgano sancionador pueda dar inicio - no, para resolver- el procedimiento sancionador. De suerte que si, transcurridos tres meses desde que se haya producido la notificación del acto de liquidación tributaria (y se ha tenido constancia de la notitia criminis), existiendo razones para proceder a sancionar al obligado tributario, el órgano que debe iniciar el procedimiento sancionador no notifica su inicio, habrá precluido o perimido la posibilidad de abrirlo, lo que significa que el plazo estudiado no lo es para dictar una resolución sino para iniciar la tramitación del expediente sancionador y, a tales plazos, el

${ }^{8}$ Para este autor caducidad significa la pérdida del ejercicio de una acción por el transcurso del tiempo, por lo que su diferencia con la prescripción resulta evidente en cuanto que prescriben los derechos y caducan las acciones, por lo tanto, el instituto de la prescripción es de apreciar en el ámbito del ejercicio de los derechos, en tanto la caducidad toma presencia en la resolución de los procedimientos, con la distinción añadida, y no menos importante, de que los plazos de prescripción se pueden interrumpir revitalizándose el plazo para el ejercicio del derecho de que se trate, en tanto que los plazos de caducidad no son susceptibles de interrupción y su término deviene inexorablemente. La perención es concepto que se predica de las actuaciones y de los procedimientos seguidos por los órganos de la Administración en general, y se produce cuando las leyes que regulan tales procedimientos y actuaciones, los someten a plazos máximos de duración, transcurridos los cuales, las actuaciones y los procedimientos se deben tener por fenecidos, produciéndose el archivo de sus actuaciones sin que ello, afecte para nada al derecho subjetivo en virtud del que dichas actuaciones se desplegaron, por aquello de que lo adjetivo -las actuaciones en los procedimientos - no puede afectar a lo sustantivo - el derecho en base al que se desarrollan las mismas- ... La preclusión es concepto jurídico que calibra, también, el paso del tiempo en el momento en que se debe iniciar un procedimiento administrativo, o en la duración de los trámites que se sustancian dentro del mismo, de suerte, que si el trámite no se cumplimenta en el plazo que la ley señala se entiende precluido sin que ello suponga, a su vez, la perención del procedimiento correspondiente en el que se inserta dicho trámite...Ahora bien, si el plazo de preclusión se establece como condición temporal del inicio de un procedimiento, éste no podrá comenzar vencido ese plazo temporal (v.gr. el del art. 209.2 LGT)... Así las cosas y a modo de síntesis, se puede afirmar que, en buena técnica jurídica, los derechos prescriben, las acciones caducan, los procedimientos administrativos perímen y los trámites procedimentales precluyen. ESEVERRI..., 2011, op. cit., págs. 229-230, 462-463.

(C) UNED. Revista de Derecho UNED, núm. 23, 2018 
ordenamiento jurídico los califica como plazos de perención o preclusión.

Otros autores ${ }^{9}$, para definir la naturaleza de la caducidad del artículo 209.2 de la LGT, se basan en la magistral construcción jurídica que, de la categoría de la caducidad, elaboró, hace ya más de medio siglo, el ilustre jurista italiano Santi Romano, deslindando las instituciones de la prescripción y de la caducidad a partir de la diferenciación de los conceptos de derecho subjetivo - poteri-, por un lado, y de potestad — potestà-, por otro, y opinan que estamos ante un plazo de caducidad del ejercicio de la potestad sancionadora de la Administración tributaria. De este modo, mientras que la prescripción tiene como objeto los derechos subjetivos, provocando el perecimiento de los mismos, la caducidad - decadenza- queda, por el contrario, referida a las potestades, conllevando la extinción, no de la potestad misma, sino de la posibilidad de ejercer ésta en un supuesto determinado. Las potestades se configuran, por tanto, como imprescriptibles, no obstante lo cual su concreta actuación sí puede

${ }^{9} \mathrm{Si}$ el concreto ejercicio de las potestades — públicas, se entiende- es susceptible de caducar (premisa A), y si la potestad sancionadora de la Administración no constituye sino una especie del género potestad (premisa B), entonces la actuación en casos determinados de dicha potestad sancionadora es, asimismo, caducable (conclusión). Consecuentemente, se derrumba la argumentación de la corriente doctrinal opuesta a la admisión de la caducidad del ejercicio del ius puniendi de la Administración. MAGRANER MORENO, F.J. y MARTÍN LÓPEZ. J.: «El límite temporal de incoación del procedimiento sancionador Tributario: los artículos 81.6 de la LGT y 209.2 del Proyecto de LGT», $Q F$, núm. 20, 2003, págs. 3 a 5; Para CABALLERO SÁNCHEZ, la actuación del ius puniendi de la Administración habría de sujetarse a un único plazo de caducidad, por ende ininterrumpible, que tendría como dies a quo el de la comisión del ilícito administrativo, y cuyo vencimiento sin haber sido incoado el oportuno procedimiento sancionador - dies ad quem - llevaría aparejada la extinción de la responsabilidad dimanante de la infracción, y el consiguiente impedimento de que la Administración ejerciese su potestad sancionadora. Y funda tal propuesta de lege ferenda en el reseñado principio de seguridad jurídica: «(...) parece más conforme con el principio de seguridad jurídica conceder a la Administración un plazo global suficientemente amplio, pero atribuyéndole carácter fatal e inapelable (...). La instauración de plazos de caducidad para la persecución de infracciones y sanciones impide interrupciones maliciosas mediante actuaciones administrativas ficticias, evita confusiones y disparidad de criterios para su apreciación, y proporciona seguridad a los ciudadanos, que pueden conocer con certeza en qué momento deja de ser perseguible un ilícito, sumando el plazo de caducidad a la fecha en que se produjeron los hechos». CABALLERO SÁNCHEZ, R.: Prescripción..., op. cit., págs. 459 a 461, y 487 a 490; MARTÍNEZ LAGO, M.A. y GARCÍA DE LA MORA, L.: Lecciones de Derecho Financiero y Tributario, Iustel, Madrid, 2009, pág. 554; Estas autoras, por el contrario, también, defienden la caducidad de la acción en la pág. 103, ANÍBARRO PÉREZ, S y SESMA SÁNCHEZ,B.: Infracciones y sanciones tributarias, Lex Nova, Valladolid, 2005, pág. 222; ANÍBARRO PÉREZ y SESMA SÁNCHEZ en la obra colectiva del Profesor CALVO ORTEGA, R. (dir.), TEJERIZO LÓPEZ, J.M. (coord..): Los nuevos reglamentos tributarios, Thomson-Civitas, Navarra, 2006, pág. 329. 
estar sujeta a caducidad. Esa teoría de las potestades, gestada por Santi Romano, de la que se derivan los referidos corolarios de la imprescriptibilidad de la potestad y de la caducabilidad de su ejercicio, ha sido ulteriormente asumida por la más acreditada doctrina científica tanto administrativista como tributarista Giannini, M.S. ${ }^{10}$, García de Enterría ${ }^{11}$ o Sainz de Bujanda ${ }^{12}$.

Para estos autores, cuya postura compartimos, la naturaleza del plazo de caducidad inicial que fija Ley General Tributaria es la de un plazo de caducidad del ejercicio de la potestad sancionadora, pues la norma establece con claridad que tras el plazo de tres meses será imposible ejercitar el ius puniendi de la Administración ${ }^{13}$. Así, ad-

${ }^{10}$ GIANNINI, M.S.: Diritto Amministrativo. Vol. II, Seconda Edizione, Giuffrè, Milano, 1988, pág. 511.

${ }^{11}$ GARCÍA DE ENTERRÍA asevera categóricamente que «las potestades son también imprescriptibles, aunque su ejercicio puede estar sometido a caducidad o decadencia.GARCÎA DE ENTERRÍA, E. y FERNÁNDEZ RODRÍGUEZ, T.R.: Curso de Derecho Administrativo I y II, Civitas, Madrid, 2002, pág. 445.

${ }^{12}$ La caducidad significa que una facultad o derecho nace con un plazo de vida y que, pasado éste, se extingue. La facultad o el derecho tienen, pues, una duración limitada. Por el contrario, la prescripción no significa que algo nazca con un plazo de vida, sino que, si durante determinado tiempo está inactivo, se extingue. Se trata, pues, de actuaciones jurídicas que, si bien son de duración ilimitada, sólo siguen durando si no se las deja en desuso». Pues bien, tras esta básica diferenciación, acepta plenamente la reseñada teoría de SANTI ROMANO: «(...) debe tenerse en cuenta que las potestades administrativas (distintas de los derechos subjetivos) no prescriben, son imprescriptibles, como consecuencia de su origen legal y su carácter genérico, sin perjuicio de que su ejercicio en cada caso singular pueda estar sometido a caducidad o decadencia». Y, refiriéndose en concreto a la prescripción de la acción para imponer sanciones tributarias regulada en la letra c) del artículo 64 de la LGT, afirma concluyentemente que, en puridad, la Administración tributaria no tiene una acción para imponer las sanciones tributarias, sino una potestad para hacerlo -ésta es, la potestad sancionadora-, que en ningún caso puede prescribir, pero sí caducar. SAINZ DE BUJANDA, F.: Lecciones de Derecho financiero, Servicio de Publicaciones de la Facultad de Derecho, Universidad Complutense, Madrid, 1991, 9. ${ }^{a}$ ed., págs. 303 y 304.

13 Considerándola como caducidad del derecho a accionar FUSTER ASENCIO, C.: El procedimiento sancionador tributario, Aranzadi, Navarra, 2001, págs. 150 y 180; JUAN LOZANO, A.M.: «El plazo para el inicio del procedimiento sancionador. Análisis de la problemática reciente y de la modificación prevista en la Ley de Acompañamiento para 2003», Tribuna Fiscal, núm. 146, 2002, págs. 65 y ss; CERVERA TORREJÓN, F., MAGRANER MORENO, F., y JUAN LOZANO, A.M.: «Análisis crítico del Reglamento por el que se desarrolla el régimen sancionador tributario (RD 1930/1998)», QF, núm. 20, noviembre de 1998; MAGRANER MORENO et alii: «El límite temporal...», op. cit.; ANÍBARRO PÉREZ, S. y SESMA SÁNCHEZ,B.: Infracciones..., op. cit., pág. 223; HERMOSÍN, M.: Procedimiento sancionador tributario. Cuestiones problemáticas, Asociación Española de Asesores Fiscales. Thomson-Aranzadi, Navarra, 2008, pág. 151; MARCOS CARDONA, M.: El procedimiento sancionador tributario, Iustel, Madrid, 2005, págs. 87 y 88; también MARTÍNEZ LAGO, M.A. y GARCÍA DE LA MORA, L.: Lecciones..., op. cit., pág. 554. 
vierten que resulta evidente que «no es plazo de prescripción porque la prescripción de la acción administrativa para imponer sanciones cuenta en la Ley con una regulación específica en el Título que regula la potestad sancionadora ${ }^{14} »$.

Existe un sector doctrinal minoritario ${ }^{15}$ que niega que se trate de un plazo de caducidad, sustentando su postura en dos motivos esenciales, porque afirman que la caducidad afecta siempre a un plazo para concluir un procedimiento y no para iniciarlo, y en segundo término, porque cuando un procedimiento caduca existe la posibilidad de volver a iniciarlo, siempre que no haya prescrito la acción de la Administración, y en este punto el artículo 209. 2 de la LGT se expresa muy claramente cuando establece que, una vez que ha transcurrido el plazo para iniciar, el procedimiento sancionador el mismo no podrá iniciarse.

Otro sector de la doctrina científica tributarista ${ }^{16}$, concibe el plazo trimestral de incoación de los procedimientos sancionadores

${ }^{14}$ MESTRE GARCÍA, E. y CERVANTES SÁNCHEZ-RODRIGO, C.J.: Guía de infracciones y sanciones tributarias, CISS, Valencia, 2005, pág. 264.

15 AGUALLO AVILÉS, A. y GANDULLO GUERRA, F.J.:Separación de los procedimientos de comprobación y sancionador. $1 .^{\text {a }}$ parte. $R E G A F$, núm. 24;. ESCRIBANO LÓPEZ, F.: «El procedimiento sancionador tributario en la Ley de Derechos y Garantías de los Contribuyentes y su desarrollo reglamentario», $R C T-E F$, núm. 196, 1999, pág. 11; No estamos en presencia de una caducidad o perención del procedimiento sino más bien ante lo que técnicamente se denomina preclusión o "preclusividad» de derechos. Como es sabido, la preclusión es un término propio del Derecho procesal que apela a la necesidad de realizar un determinado acto dentro del procedimiento en una fase, espacio o momento taxativamente señalado por la norma, de tal suerte que vencido ese plazo sin haberse realizado se pierde toda posibilidad futura de ejecutarlo. Bien es verdad que, aun siendo institutos diferentes, la preclusión o "preclusividad» de los derechos está estrechamente relacionada con la perención, ya que en ocasiones se manifiesta en el curso de un procedimiento que puede tener prefijado un plazo para su terminación. FERNÁNDEZ LÓPEZ, R.I.: «La discutible diferenciación entre la autorización de inicio del procedimiento sancionador tributario y el inicio formal del expediente», JT, 2006, BIB 2006\633.

${ }^{16}$ La LGT se ha limitado a establecer un plazo de caducidad del ejercicio de la potestad para imponer sanciones, pero dicho plazo no constituye,exactamente, un plazo de prescripción de la acción para sancionar porque tal y como se configura en la Ley no admite interrupción, en cambio sí podría suspenderse. JUAN LOZANO, A.M.: «El plazo ...», op. cit., págs. 65 a 67; En virtud de esta figura jurídica, «no es que se extinga la responsabilidad, como sucede con la prescripción, es que se extingue la acción para exigir aquélla. Se somete la acción para exigir la responsabilidad administrativa, en cuyo ejercicio la Administración habrá de acordar la incoación del expediente sancionador, a una condición objetiva de carácter extintivo (...). La acción para exigir la responsabilidad del infractor puede estar sometida a plazo; esto es, puede perjudicarse de no ser ejercitada a tiempo. Es decir, de no incoarse oportunamente el procedimiento sancionador. No estamos, pues, ante un plazo de prescripción (extintivo de la responsabilidad), ni ante un plazo de perención (extintivo de un procedimiento, pues éste aún no está incoado), sino ante un 
tributarios previsto en el artículo 209.2 de la LGT como un supuesto de caducidad de la acción de la Administración tributaria para perseguir las infracciones tributarias - acuñado asimismo como de caducidad de la acción sancionadora-, sosteniendo que constituye el objeto de esta manifestación del instituto jurídico de la caducidad la acción de la que es titular la Administración tributaria para exigir la responsabilidad derivada de la comisión del ilícito tributario. En definitiva, puede existir una auténtica disociación entre potestad sancionadora y acción administrativa para su ejercicio, que dará lugar a supuestos de procedimientos perimidos, con acción caducada y potestad sancionadora no prescrita, o, simplemente, de acción caducada y sanción no prescrita ${ }^{17}$.

En cualquier caso, lo realmente claro es que el referido plazo máximo de inicio de los procedimientos sancionadores tributarios no constituye, en modo alguno, un plazo de caducidad del procedimiento, puesto que resulta de todo punto insostenible predicar la caducidad de un procedimiento sancionador tributario que todavía no ha sido incoado. Repárese en que se trata de un plazo articulado precisamente para que la Administración tributaria inicie dentro del mismo el procedimiento sancionador tributario, por lo que mal puede caducar un procedimiento que ni tan siquiera existe. Tampoco puede ser catalogado como de prescripción, por la ininterrumpibilidad de su cómputo, aunque el efecto jurídico originado por

plazo de caducidad de la acción». GÓMEZ PUENTE, M.: La inactividad de la Administración, Aranzadi, Navarra, 2002, págs. 430 a 435; JUAN LOZANO, A.M.: "Propuestas de introducción de técnicas de simplificación en el procedimiento sancionador tributario", $R E D F$, núm. 117, Madrid, 2003, págs. 25 y 26; Se trata de un plazo de caducidad de la acción dentro del plazo de prescripción. BLASCO DELGADO, C.: La prescripción de las infracciones y las sanciones, Civitas, Madrid, 2003, págs. 108 a 115; y 213 a 216; Es el caso de la mal llamada caducidad del procedimiento administrativo, que, en realidad, se refiere a la perención del procedimiento. Sin ánimo de sentar definitivamente doctrina sobre esta disparidad de instituciones, y de conceptos para referirse a ellas, y a los solos efectos de este breve estudio, diremos que, a nuestro juicio, los derechos prescriben, las acciones caducan, los procedimientos perímen y los trámites precluyen. DE JUAN CASADEVALL, J.: «La caducidad...», op. cit.; pues su transcurso sin haberse iniciado el procedimiento sancionador provoca efectos extintivos puesto que impide materialmente la iniciación del procedimiento. ANÍBARRO PEREZ, B. y SESMA SÁNCHEZ, S.: Infracciones..., op. cit., pág. 103; También de ese parecer la STSJ de Madrid de 22 de enero de 2009 (FJ 6); En la doctrina administrativa DE DIEGO DÍEZ, L.A.: Prescripción y caducidad en el Derecho administrativo sancionador, Bosch, Barcelona, 2006, págs. 188-189 (para este autor no se trata de caducidad del procedimiento, porque éste aún no se ha iniciado, sino de una excesiva demora en la decisión sobre si procede o no incoar procedimiento sancionador tras contar la Administración con todos los datos al respecto: lo que caduca es precisamente la posibilidad de iniciar el procedimiento).

17 DE JUAN CASADEVALL, J.: «La caducidad...», op. cit. 
el vencimiento de dicho plazo sin que la Administración tributaria haya iniciado el expediente sancionador tributario es, en esencia, idéntico al que acarrea la prescripción de la responsabilidad derivada de la comisión de la infracción tributaria ${ }^{18}$. La imposición de sanciones tributarias se efectúa no a través del ejercicio de una acción o derecho de la Administración, sino mediante la actuación de la potestad administrativa sancionadora.

Sobre el plazo de caducidad en la terminación del procedimiento, algunos autores ${ }^{19}$, han defendido, que se trata de un plazo de caducidad la acción, afirmando que «aunque, en rigor, el efecto jurídico que se asocia a dicho incumplimiento va más allá de la simple perención, para producir una auténtica caducidad de la acción, al vedar el propio art. 211.4 LGT la iniciación de otro procedimiento sancionador, aunque no haya prescrito el plazo para imponer las correspondientes sanciones que establece el art. 189 LGT.»

Otros autores ${ }^{20}$ han defendido que el plazo del artículo 211, apartados 2 y 4, de la LGT es un plazo de caducidad del procedimiento

18 MAGRANER MORENO, F.J. y MARTÍN LÓPEZ. J.: «El límite temporal...», op. cit., pág. 13.

19 DE JUAN CASADEVALL, J.: «La caducidad...», op. cit.; A diferencia de la perención, que evita la pendencia indefinida, la caducidad de la acción presupone la temporalidad congénita de los derechos y su sujeción a un plazo extintivo. MARCOS CARDONA, M.: El procedimiento..., op. cit., pág. 87; Se trata de un plazo de caducidad o decadencia de derechos distinto de la perención del procedimiento, según el cual, transcurrido el plazo fijado, caduca el derecho de acción para perseguir la infracción. La caducidad supone la existencia de derechos temporales, sujeto a un plazo extintivo fijado por la Ley, implicando la temporalidad de derechos, y una vez transcurrido el plazo decae el derecho. FUSTER ASENCIO, C.: El procedimiento..., op. cit., pág. 150. CERVERA TORREJÓN, F.; MAGRANER MORENO, F.J. y JUAN LOZANO, A.M.: "Análisis crítico...», op. cit., pág. 19;También las SsTSJ de Canarias de 25 de enero de 2009 (FJ3. ${ }^{\circ}$ ), de Madrid, de 3 de mayo de 2006 (FJ 6..$^{\circ}$ ) « la auténtica novedad a la que nos referimos y supone la imposibilidad de que la Administración pueda, una vez declarada la caducidad del expediente sancionador, iniciar otro sobre los mismos hechos y contra el mismo sujeto pasivo infractor. El efecto jurídico que se asocia a dicho incumplimiento va más allá de la simple perención, para producir una auténtica caducidad de la acción, al vedar el propio art. 211.4 LGT la iniciación de otro procedimiento sancionador, aunque no haya prescrito el plazo para imponer las correspondientes sanciones que establece el art. 189 LGT»; de Madrid de 21 de septiembre de 2006 (FJ 8. ${ }^{\circ}$ ); de Madrid de 22 de enero de 2009 (FJ 6. ${ }^{\circ}$ ); De este parecer es PÉREZ ROYO, F.: Derecho Financiero..., 2009, op. cit. pág. 428.

${ }^{20}$ ANÍBARRO PÉREZ y SESMA SÁNCHEZ en la obra colectiva del Profesor CALVO ORTEGA, R. (dir.), TEJERIZO LÓPEZ, J.M. (coord.): Los nuevos reglamentos..., op. cit., págs. 344; ANÍBARRO PÉREZ, B. y SESMA SÁNCHEZ, S.: Infracciones y..., op. cit., pág. 246; BLASCO DELGADO, C.: La prescripción..., op. cit., pág. 112; MORILLO MÉNDEZ, A.: «Caducidad y procedimientos tributarios», GF, núm. 170, 1998, pág. 1998; Perención del procedimiento sancionador: GONZÁ- 
y ello aunque tenga efectos fatales para el procedimiento y vaya en contra de lo que recoge el derecho administrativo sancionador común, al impedir que se inicie de nuevo el procedimiento sancionador.

\section{I.4. Fundamento}

Como fundamento de la caducidad debemos señalar que el tiempo constituye un límite al ejercicio de la potestad sancionadora, y que la producción de la caducidad obedece al transcurso de un plazo establecido sin que se haya producido una determinada actuación administrativa, y ello con independencia de que exista una voluntad procedimental de la Administración dirigida a su realización, bien entendido que el ejercicio de la potestad sancionadora, por su propia configuración, responde a plazos de prescripción y no de caducidad $^{21}$.

\section{ELEMENTOS DE LA CADUCIDAD}

\section{II.1. Inactividad del órgano competente sancionador tributario}

Toda caducidad del procedimiento sancionador tributario comporta una paralización -caducidad en la terminación del procedimiento- o falta de iniciación — caducidad en la incoación del procedimiento- por parte de la Administración, sin causa justificada, del procedimiento administrativo sancionador.

Dicha no actuación debe ser cometida por los titulares de los órganos competentes para incoar, instruir o para resolver, según el momento procedimental en que nos encontremos.

LEZ PÉREZ, J. y GONZÁLEZ NAVARRO, F.: Comentarios a la Ley de Régimen Jurídico de las Administraciones Públicas y Procedimiento Administrativo Común, vols. I y II, Civitas, Madrid, 1997, pág. 1357; MESTRE GARCÍA, E. y CERVANTES SÁNCHEZ-RODRIGO, C.J.: Guía de infracciones..., op. cit., págs. 283 y 284; ANEIROS PEREIRA, J.: Las sanciones tributarias, Marcial Pons, Madrid, 2005, pág. 211; COLLADO COLLADO YURRITA, M.A. (dir.); LUCHENA MOZO, G.M. (coord.) et alii: Derecho Tributario. Parte General, Atelier, Barcelona, 2007, pág.41; FERREIRO LAPATZA, J.J.: Curso de Derecho Financiero Español: Instituciones, Marcial Pons, Madrid, 2006, pág. 563.

${ }^{21}$ GARBERÍ LLOBREGAT, J. et alii: El procedimiento administrativo sancionador..., op. cit., pág. 142.

(C) UNED. Revista de Derecho UNED, núm. 23, 2018 


\section{II.2. Tipos de procedimientos tributarios susceptibles de caducidad sancionadora tributaria}

En principio, la caducidad en la iniciación y terminación del procedimiento sancionador tributario se aplicará a todas las tipologías de procedimientos sancionadores tributarios derivados de procedimientos de aplicación de los tributos, así encontraremos el de carácter general u ordinario, y el abreviado del artículo 210.5 de la LGT.

De igual modo, dicha caducidad se aplicará a todas las modalidades de tramitación del procedimiento ${ }^{22}$ sancionador en materia tributaria, a que se refieren los artículos 208.1 de la LGT y 21.1 del RGRST. Esta tramitación se podrá realizar tanto de forma sepa$\operatorname{rada}^{23}$ a la de la aplicación de los tributos regulada en el título III de la LGT, como de forma conjunta en caso renuncia del obligado tributario, con la única salvedad del procedimiento sancionador inspector tramitado de manera conjunta con el procedimiento de inspección.

22 Tanto el artículo 208.1 LGT como el artículo 21.1 RGRST hablan de «procedimiento» en singular, lo cual no dejar de ser un eufemismo, puesto que podemos distinguir hasta diez tipos de procedimientos, así en los de inspección y en los derivados de otras actuaciones, se subdividen en procedimientos con o sin renuncia a la tramitación separada, y a su vez, cada uno de dichos subtipos, en otros dos subtipos el ordinario y el abreviado. Por último debemos también distinguir el procedimiento sancionador en actas con acuerdo y el previsto para sanciones no pecuniarias. LAMOCA PÉREZ, C.: Infracciones y sanciones tributarias. Análisis crítico del nuevo sistema de infracciones y sanciones en la Ley General Tributaria, CEF, Madrid, 2005, págs. 460 y 461. De igual modo cuando se habla de tramitación de forma separada o conjunta, es precisamente la tramitación la que se realiza de modo conjunta o separada, en cualquiera de los casos el procedimiento no es conjunto, sino separado y autónomo, aunque en las actas con acuerdo sea meramente testimonial. De igual modo, el artículo 208.1 establece que debe ser el obligado tributario el que renuncie a la tramitación separada, cuando los sujetos infractores no siempre coinciden con el concepto de obligado tributario del art. 35 LGT, v.gr. en grupos consolidados, el grupo es el obligado, y la sociedad dominante la infractora. Sin embargo, el art. 21.1 RGRST abre el concepto al de «interesado», vocablo de dimensiones más amplias que la de obligado y la de sujeto infractor.

${ }^{23}$ La razón de ser de separar los procedimientos se encuentra en que la función liquidadora es ontológicamente distinta a la sancionadora 3; la primera tiene por objeto cuantificar el importe de la obligación tributaria, materializando así el deber de contribuir al sostenimiento de los gastos públicos, mientras que el objeto de la segunda es reprender el incumplimiento del orden jurídico para prevenir futuros incumplimientos. Pero no es sólo que las funciones sean distintas, sino que los procedimientos a través de los cuales hayan de ser ejercidas se rigen por principios diversos. RICARDO HOYOS, J.: «El procedimiento sancionador tributario como procedimiento separado», $Q F$, núm. 3, 2001. 
La redacción del artículo 209.2 de la Ley General Tributaria ha introducido una auténtica limitación ${ }^{24}$ temporal para la iniciación del procedimiento sancionador, que únicamente ${ }^{25}$ operará en los casos en los que se incoe como consecuencia de un procedimiento iniciado mediante declaración del contribuyente ${ }^{26}$

${ }^{24}$ Así quedan excluidos algunos procedimientos, aunque sus efectos, en algunos casos, distan de incurrir en el supuesto de hecho de las infracciones tributarias tipificadas en la LGT, así:

—El de devolución iniciado mediante autoliquidación, solicitud o comunicación de datos, regulado en los artículos 122 a 125 del RD 1065/2007; De detectarse algún incumplimiento, y modificarse la cantidad a devolver, dicha modificación debería hacerse en el ámbito de otro procedimiento distinto del de declaración, de modo que terminando de un modo diferente al de la devolución de los mentados en el art. 127 LGT, será cualquiera de esos procedimientos el que estaría sujeto a plazo el posterior proceso sancionador. MESTRE GARCÍA, E. y CERVANTES SÁNCHEZ-RODRIGO, C.J.: Guía de infracciones..., op. cit., pág. 263; ANÍBARRO PÉREZ y SESMA SÁNCHEZ en la obra colectiva del Profesor CALVO ORTEGA, R. (dir.), TEJERIZO LÓPEZ, J.M. (coord.): Los nuevos reglamentos..., op. cit., págs. 328 y 329.

- El de rectificación de autoliquidaciones, declaraciones, comunicaciones de datos o solicitudes de devolución, regulado en los artículos 126 a 130 del RD 1065/2007.

—El ejecución de devoluciones tributarias, regulado en los artículos 131 a 132 del RD 1065/2007.

- El de reconocimiento de beneficios fiscales de carácter rogado, regulado en los artículos 136 a 137 del RD 1065/2007.

- El inclusión en el sistema de cuenta corriente tributaria, regulado en los artículos 138 a 143 del RD 1065/2007.

- Los iniciados como consecuencia de procedimientos de recaudación, regulados en el Real Decreto 939/2005, de 29 de julio, por el que se aprueba el Reglamento General de Recaudación, aludidos el artículo 20.3. ${ }^{\circ}$ RD 2064/2003.

- Procedimiento de obtención de información mediante requerimientos de información a terceros por la Inspección, regulado en los arts. 93 a 95 LGT y 30 a 58 RGGI.

25 GARBERÍ LlOBREgAT, J. (dir.); BUITRÓN RAMÍREZ, G. et alii: Procedimiento Sancionador. Infracciones y Sanciones Tributarias. (Comentarios, Jurisprudencia, Formularios, Ejemplos Prácticos y Legislación). T. I. Tirant Lo Blanch,Valencia, 2005, pág. 1.116; Se refiere a procedimientos iniciados mediante declaración, de verificación de datos, de comprobación limitada y de inspección. No se regula a nivel legal ni a nivel reglamentario el plazo de iniciación de los restantes procedimiento que pudieran instruirse.....En estos casos...habrá que tenerse en cuenta el plazo de cuatro años de prescripción al momento de la comisión de la infracción que se sanciona; en ese sentido DÍEZ OCHOA, J.M.: Derecho Tributario Sancionador. Comentarios y casos prácticos, CEF, Madrid, 2005, pág. 513.

${ }^{26}$ Regulado en los artículos 128 a 130 LGT y 133 a 135 del RD 1065/2007, de 27 de julio.

(C) UNED. Revista de Derecho UNED, núm. 23, 2018 
o de un procedimiento de verificación de datos ${ }^{27}$, comprobación ${ }^{28} \mathrm{o}$ inspección ${ }^{29}$.

Debemos remarcar, preliminarmente ${ }^{30}$, que para iniciar cualquier expediente sancionador no es necesario que haya concluido con carácter previo un procedimiento de comprobación o de aplicación de los tributos ${ }^{31}$.

Considerado que el plazo de caducidad para la incoación del procedimiento sancionador solamente afecta a los procedimientos enunciados en el artículo 209.2 de la LGT, cualquier otro tipo ${ }^{32}$ de

${ }^{27}$ Regulado en los artículos 155 y 156 del RD 1065/2007, de 27 de julio, y en los artículos 131 a 133 LGT.

${ }^{28}$ Regulado en los artículos 134 a 140 LGT, y 144 a 154, 157 a 162, y 163 a 165 RGGI.

${ }^{29}$ Regulado en los artículos 166 a 197 del RD 1065/2007, de 15 de julio, y 141 a 159 LGT,

30 Esta aseveración la matizaremos y desarrollaremos en el apartado (5.2.3.1.) que trata la caducidad en la iniciación del procedimiento sancionador tributario.

31 ANÍBARRO PÉREZ, S. y SESMA SÁNCHEZ, B.: Infracciones..., op. cit., pág. 228; y la RTEAC de 9 de octubre de 2002.

32 ¿Quiere ello decir que como afirman algunos autores (DE ENTERRÍA, SANTAMARÍA) la declaración de caducidad es un iter inutilis? Creemos que no. De un lado, dado que el plazo que ha durado el procedimiento caducado no interrumpe la prescripción, es frecuente que ésta se haya consumado (p. ej. en plazos de prescripción de sanciones) y que la Administración no pueda ya abrir un segundo procedimiento. De otro lado, la práctica demuestra que es habitual que la Administración, de hecho, no proceda a la apertura de un nuevo procedimiento, de forma que la caducidad supone frecuentemente la extinción definitiva del procedimiento. La doctrina (DE ENTERRÍA, SANTAMARÍA) suele cuestionar la utilidad de la caducidad de los procedimientos administrativas por el hecho de que la misma no impide a la Administración volver a abrir un segundo procedimiento sobre los mismos hechos que motivaron el caducado, de forma que la declaración de caducidad sería un iter inutilis. Sin embargo, a esa opinión de los doctos autores puede objetarse: en primer lugar, que si bien la posibilidad de abrir un nuevo procedimiento que reemplace al caducado sigue siendo la regla común, a partir de la Ley General Tributaria de 2003 tiene ya la importante excepción de los procedimientos sancionadores tributarios que, una vez caducados, impiden iniciar uno nuevo (art. 211.4); en segundo lugar, hay que tener en cuenta que la apertura de un nuevo procedimiento en sustitución del caducado solo será posible en la medida en que no se haya producido la prescripción y - teniendo en cuenta el importantísimo efecto que produce la caducidad del expediente administrativo consistente en que no interrumpe el plazo de prescripción-, no es infrecuente que cuando la Administración intenta abrir un nuevo procedimiento, la prescripción (p. ej.: de sanciones) se haya consumado; por último, no debe olvidarse que los expedientes administrativos caducados, en la práctica, rara vez se rehabilitan, de forma que la extinción provisional que la caducidad representa se convierte realmente en numerosas ocasiones en una extinción definitiva. Por eso, una de las primeras cuestiones que cualquier letrado habrá de examinar en todo procedimiento administrativo es la de ver si el mismo ha respetado o no los plazos máximos legales de duración del mismo y, en consecuencia, si el acto administrativo se ha dictado o no en un procedimiento caducado. RODRÍ- 
procedimiento, como pudiera ser el que se iniciara merced a una denuncia $^{33}$ de infracciones tributarias, no tendría plazo preclusivo, cuyo

GUEZ CARBAJO, J.R.: «La caducidad de los procedimientos administrativos», Actualidad Administrativa, núm. 9, Sección Fundamentos de Casación, quincena del 1 al 15 May. 2009, pág. 1095, tomo 1, Editorial LA LEY.

${ }^{33}$ La denuncia pública constituye un instrumento de colaboración social voluntaria en defensa del interés general. Al igual que su precedente (el art. 103 de la anterior LGT 1963), el número 1 del artículo 114 LGT contiene implícitamente esta declaración de voluntariedad, al señalar que el ejercicio de la denuncia «es independiente del deber de colaborar con la Administración tributaria regulado en los artículos 93 y 94 de esta Ley»; preceptos que imponen a distintos sujetos, tanto privados como públicos, diferentes deberes de colaboración consistentes en el suministro de información que conozcan por sus relaciones con terceros... Al igual que su precedente, el artículo 114.1 habla de «denuncia pública», pues tanto la doctrina de Derecho Administrativo como de Derecho Tributario coinciden en señalar que, a través de la denuncia, el particular lleva a cabo funciones materialmente públicas. Al ser una denuncia "pública» puede ser formulada por cualquiera. Así lo subrayó la Resolución del TEAC de 19 de octubre de 1988... El artículo 103.1 LGT 1963 establecía que la denuncia pública podía ser hecha por cualquier persona física o jurídica con capacidad de obrar en el ámbito tributario. Ahora, el artículo 114 LGT 2003, omite esta referencia. Por pura lógica, no podrían ser denunciantes los sujetos pasivos del tributo, pues están inmersos en una relación jurídica tributaria, y tampoco lo pueden ser sus representantes. Se discute si los responsables pueden ser denunciantes. Con carácter general, puede decirse que, al enmarcarse la denuncia dentro del derecho general a colaborar con la Hacienda Pública, algo distinto de la obligación de aportar información, la puede plantear cualquier persona, tenga o no interés en el asunto. En concreto, SÁNCHEZ GALIANA defiende que «nada impediría, y máxime con la genérica redacción del precepto, la posibilidad de ejercitar la denuncia pública por parte de un responsable tributario, lo cual podría, ciertamente, conllevar una elusión de su responsabilidad, no ya por vulneración de ningún precepto legal, sino simplemente como consecuencia de haberse hecho efectiva la deuda tributaria de la que se era responsable, precisamente por la actuación administrativa derivada de la denuncia realizada contra el sujeto pasivo... Según el artículo 114.1 LGT, la denuncia ha de versar sobre hechos o situaciones, que puedan ser constitutivos de infracciones tributarias o tener trascendencia para la aplicación de los tributos. De ordinario, los hechos o situaciones denunciados, una vez verificados, determinarán la apertura del procedimiento sancionador, pues lo normal será que hayan supuesto una ocultación de ingresos o un incumplimiento de deberes. Desaparece la mención a que el denunciante conozca los hechos o situaciones pues, como señaló GARCÍA LUIS, era superflua ya que lo que no se conoce no puede ser denunciado... La nueva LGT amplía las causas de inadmisión previstas en la anterior LGT a los casos en que no se concreten o identifiquen suficientemente los hechos o las personas denunciadas... La denuncia pública no constituye ningún modo de iniciación de las actuaciones y procedimientos tributarios. Constituye un acto previo al procedimiento administrativo — puesta en conocimiento de la Administración Tributaria de determinados hechos o situaciones-que, en su caso, hará que se inicie y que no forme parte del mismo. De hecho, la denuncia no viene recogida en el artículo 118 LGT como una de las formas de inicio de los procedimientos tributarios... En definitiva, ahora la denuncia es sólo un mecanismo de obtención de información por parte de la Administración que deberá decidir en cada caso, en función de las circunstancias concurrentes y de los indicios de veracidad que resulten de la denuncia, el inicio o no de actuaciones de comprobación... 
único límite será el de la prescripción de la infracción. Significativamente, los procedimientos sancionadores provocados por procedimientos de obtención de información no estarían, tampoco, sujetos a este plazo, el cual básicamente trata de acercar lo más posible en el tiempo el conocimiento total de todo el coste de la regularización material al obligado tributario.

Expuesto lo anterior, debe manifestarse que la LGT no ha resuelto el problema del inicio de procedimientos sancionadores respecto de procedimientos de gestión que han caducado. A juicio de Aníbarro Pérez y Sesma Sánchez ${ }^{34}$, en estos casos no podrá iniciarse proce-

El apartado 2 del artículo 114.2 LGT dispone que «Se podrán iniciar las actuaciones que procedan si existen indicios suficientes de veracidad en los hechos imputados y éstos son desconocidos para la Administración tributaria. En este caso, la denuncia no formará parte del expediente administrativo». El hecho de que la denuncia no forme parte del expediente tiene sus consecuencias tanto para el denunciante como para el denunciado, .... Lo que sí formará parte del expediente es la documentación aportada por el denunciante que haya sido utilizada en el desarrollo de las actuaciones inspectoras y vaya a ser tenida en cuenta a la hora de formular la propuesta de regularización... Según el artículo 114.3 LGT, «No se considerará al denunciante interesado en las actuaciones administrativas que se inicien como consecuencia de la denuncia ni se le informará del resultado de las mismas. Tampoco estará legitimado para la interposición de recursos o reclamaciones en relación con los resultados de dichas actuaciones» (STS de 16 de diciembre de 1992)..., puesto que la denuncia no forma parte del expediente administrativo, entienden algunos [los Profesores del CEF, MARTÍN QUERALT, LOZANO SERRANO, TEJERIZO LÓPEZ y CASADO OLLERO, FERNÁNDEZ-VÁZQUEZ MAESO, M.A.; CHICO ARAGÓN, L.; PELÁEZ MARTOS, J.M.; FUENTES GIMÉNEZ, J.A.; GALÁN HERNÁNDEZ, T.; GUAITA GIMENO, J.J.] que no hay obligación por parte de la Administración tributaria de poner en conocimiento del obligado tributario en el procedimiento que se inicie que existió una denuncia. Lo que está claro es que, al no formar parte del expediente, el denunciado no va a tener acceso al contenido de la denuncia.... APARICIO PÉREZ considera que no es posible admitir una denuncia anónima por razones de legalidad (la LGT exigía al denunciante capacidad de obrar, que en el caso de la denuncia anónima no se podía contrastar) —evidentemente, este motivo no es defendible con la nueva LGT-y por razones de seguridad jurídica, que puede afectar tanto a la Administración como al denunciado (por ejemplo, por presentarse denuncias falsas frente a las que no sería posible reaccionar). Pero es que, además, las denuncias anónimas (por ejemplo, simple llamada telefónica desde una cabina pública, carta anónima, etc.) pueden esconder la obtención de información mediante la vulneración de derechos fundamentales o la comisión de un delito por el denunciante; en concreto, el de revelación de secretos ajenos llevada a cabo por persona con relación laboral o similar y la divulgación de secretos por profesionales especialmente obligados al sigilo o reserva. Por ello, a nuestro juicio, las denuncias anónimas nunca deberían ser tenidas en cuenta por la Administración para iniciar un procedimiento de comprobación. BURLADA ECHEBESTE, J.L.; BURLADA ECHEBESTE, I.M.: «La denuncia pública en el derecho tributario. Cuestiones sustantivas de los nuevos procedimientos tributarios (2)», Quincena Fiscal, Aranzadi, núm. 6, 2010. BIB 2010 275.

${ }^{34}$ ANÍBARRO PÉREZ, S. y SESMA SÁNCHEZ, B.: Infracciones y sanciones tributarias..., op. cit., pág. 226; El problema podría plantearse cuando, a pesar de ha- 
dimiento sancionador porque no existe notificación de liquidación o resolución expresa del procedimiento que es el momento a partir del cual se computan los tres meses ex artículo 209.2 de la LGT, sin perjuicio que, de conformidad con el artículo $104.5 .^{\circ}$ de la LGT se pueda iniciar de nuevo el procedimiento caducado, y como consecuencia del mismo, el procedimiento sancionador.

\section{II.3. Transcurso del plazo}

En el procedimiento sancionador, debemos preguntarnos si existe algún límite temporal que le afecte —además del plazo de prescripción de cuatro años- ${ }^{35}$.

Hay que tomar como premisa que en los procedimientos iniciados de oficio, como el sancionador tributario ${ }^{36}$, el vencimiento del plazo máximo establecido [para dicho procedimiento] sin que se

ber caducado el procedimiento se dictara con posterioridad al mismo resolución expresa. En este caso, a nuestro juicio, entendemos que desde esta fecha comenzaría a computarse el plazo trimestral de inicio del respectivo expediente sancionador. ANÍBARRO PÉREZ, S. y SESMA SÁNCHEZ, B. en la obra colectiva del Profesor CALVO ORTEGA, R.: ..., op. cit., pág. 329.

35 ANEIROS PEREIRA, J.: Las sanciones..., op. cit., pág. 201; La prescripción y la caducidad vienen a ser mecanismo destinados a garantizar que el interés general se satisfaga en un tiempo determinado, evitando situaciones de inseguridad jurídica a los ciudadanos. Con ello debe prescindirse de un planteamiento falaz que está presente en muchas ocasiones, la prescripción y la caducidad tienden a beneficiar a un ciudadano hábil que sabe eludir con artimañas jurídicas la actuación de la Administración durante un tiempo determinado, mientras que son un mecanismo de castigo dirigido a sancionar a los funcionarios negligentes que con su pasividad no cumplen diligentemente con su trabajo. AGUADO I CUDOLA, V.: Prescripción..., op. cit., pág. 19.

36 El artículo 208 de la LGT reconoce el derecho al procedimiento que, como exigencia constitucional, se proyecta de forma intensa sobre las sanciones, tal y como viene señalando la jurisprudencia de nuestro Tribunal Constitucional, así desde la STC 18/1981, de 8 de junio, las SsTC 93/2001, de 2 de abril, 23/2002, de 29 de enero, 276/2000, de 16 de noviembre, 194/2000, de 19 de julio, 14/1999, de 22 de febrero, se han extendido las garantías procesales del artículo 24 de la CE al ámbito administrativo sancionador, excluyendo las sanciones impuestas se plano, así las SsTSJ de Valencia de 3 de marzo de 2001, de Murcia de 30 de marzo de 2002, de Andalucía de 11 de enero de 2002. También SUAY RICÓN, J. et alii: Los principios del procedimiento sancionador. La Ley de Régimen Jurídicos de las AA.PP. y del Procedimiento Administrativo Común, Tecnos, Madrid, 1993, pág. 384; Sin embargo, no fue hasta la aprobación de la LDGC cuando se logró la plasmación expresa de esta garantía que pasó a recogerse en su art. 34 citado por PALAO TABOADA, C.: «Lo blando y lo duro del proyecto de ley de derechos y garantías de los contribuyentes», $R C T-E F$, núm. 171, 1997, pág. 27; SESMA SÁNCHEZ, B.: "Aspectos críticos de la nueva regulación del procedimiento sancionador tributario», RTT, núm. 42, 1999, pág. 93. 
haya notificado resolución expresa producirá los efectos previstos en la normativa reguladora de cada procedimiento, en concreto, en los procedimientos susceptibles de producir efectos desfavorables o de gravamen se producirá la caducidad del procedimiento ${ }^{37}$.

Al hilo de anterior cuestión, el artículo 209.2. ${ }^{\circ}$ de la LGT establece un plazo de caducidad máximo para el inicio del procedimiento sancionador que deba incoarse como consecuencia de la terminación de un procedimiento iniciado mediante declaración o de un procedimiento de verificación de datos, comprobación o inspección, sin embargo, suscitamos la duda de qué ocurre en el caso de cualquiera de estos últimos procedimientos termine mediante caducidad y el procedimiento sancionador tributario ya estuviera incoado. Estimamos ${ }^{38}$ que las actuaciones realizadas en el curso de un procedimiento caducado, así como los documentos y otros elementos de prueba obtenidos en dicho procedimiento, conservarán su validez y eficacia a efectos probatorios en otros procedimientos iniciados - como el sancionador- o que puedan iniciarse con posterioridad - como el sancionador- en relación con el mismo u otro obligado tributario, ex artículo $104.5^{\circ}$ de la LGT.

Por nuestra parte, podemos considerar ${ }^{39}$ que el procedimiento sancionador tributario ya iniciado, a consecuencia de otro de aplica-

${ }^{37}$ En igual sentido, el art. 104.4. ${ }^{\circ}$.b) LGT, para los procedimientos de aplicación de los tributos.

38 Así, en base al principio de eficacia en el funcionamiento de las Administraciones Públicas, BAYONA GIMÉNEZ, J.J.: La caducidad..., ob. cit., pág. 132; «una cosa es que por la inactividad administrativa la Ley ordene finalizar el procedimiento y abstenerse de resolver sobre el fondo del mismo, y otra bien distinta, es que el archivo del procedimiento suponga la nulidad de todos y cada uno de los actos válidos y eficaces». FENELLÓS PUIGCERVER, V.: «La duración de las actuaciones inspectoras. El nuevo artículo 29 de la Ley 1/1998. Una concesión a los intereses particulares», Tribuna Fiscal, núm. 96, 1998, pág. 79; PÉREZ ROYO, I.: «La prescripción en las actuaciones inspectoras», $R E D F$, Civitas, núm. 96, 1996, pág. 569; En contra de mantener dichas actuaciones, pues las consideran borradas del procedimiento, teniéndolas por inexistentes: HERNÁNZ MARTÍN, A.: «El tiempo en las actuaciones inspectoras», Impuestos, núm. 8, 2003, pág. 21; HERNÁNZ MARTÍN, A. y RÍO RODIL, C.: "Comentarios al Proyecto de Ley General Tributaria», Impuestos, 13, 2003, págs. 19 y 20; GARCÍA NOVOA, C.: El silencio administrativo en Derecho Tributario, Aranzadi, Navarra, 2001, pág. 93: «La Administración no podrá servirse de datos jurídicamente relevantes y de todo aquello que traiga su causa de unas actuaciones caducadas».

${ }_{39}$ Así GARBERÍ LLOBREGAT, J. et alii: ..., op. cit. T. II, pág. 1353 escribe, en relación a la denuncia tributaria contemplada en el artículo 114 LGT, "Y todo ello porque una cosa es la iniciación del expediente sancionador y otra bien distinta la iniciativa para su promoción, la cual, subordinada al conocimiento de la posible comisión de una infracción administrativa (notitia criminis), pueda dar lugar a que el órgano competente incoe el correspondiente procedimiento. En suma, la inicia- 
ción de los tributos con posterioridad caducado, no deba entenderse caducado, puesto que el inicio del procedimiento sancionador es, en cualquier caso, de oficio. Única y concretamente para los procedimientos de verificación de datos, comprobación o inspección, se establece un límite temporal, una vez finalizados los mismos, para la incoación del procedimiento sancionador, lo que no significa que el sancionador pueda haberse incoado con anterioridad.

a) Fundamento del límite temporal de la caducidad sancionadora tributaria

El fundamento o la justificación de semejante límite temporal hay que encontrarlo en el principio constitucional de la seguridad jurídica recogido en el artículo 9.3 de la Constitución Española. La pretensión es que, una vez advertida la comisión de una infracción tributaria por parte de las autoridades u órganos competentes, la formalización de la imputación, en contra del sujeto a quien quepa imputar su comisión, no se demore durante mas tiempo del que resulte razonable para preparar adecuadamente dicha imputación, tiempo razonable que el legislador ha cifrado, en el artículo 209.2 de la LGT en un período máximo de tres meses. Una vez preparada dicha imputación, y con la finalidad de salvaguardar la seguridad jurídica, el artículo 211.4 de la LGT, limita a seis meses, contados desde la notificación de su inicio, el plazo máximo para notificar la terminación del procedimiento sancionador tributario. De este modo, mientras los dilatados plazos de prescripción de los ilícitos tributarios juegan, en general, en favor de la Administración, que dispone de este modo de un longevo período de tiempo para poder constatar debidamente la existencia de un comportamiento infractor, dichos beneficiosos plazos para la acción publica represiva han de dejar de operar en cuanto la Administración disponga ya de los datos necesarios para formalizar, con razonables garantías de éxito, una imputación concreta frente a un sujeto igualmente determinado.

ción del expediente sancionador únicamente puede realizarse por acuerdo del órgano competente (art. 22 RGRST), acuerdo cuya emisión podrá venir motivada en atención a las distintas iniciativas de las que se hace eco los arts. 58 a 64 de la Ley 39/2015, de 1 de octubre, del Procedimiento Administrativo Común de las Administraciones Públicas - LPACAP - [con anterioridad enumerados en el derogado art. 11.1 del Real Decreto 1398/1993, de 4 de agosto - RPS - , alguna de las cuales (como sucede con la denuncia) también contempla de forma expresa la LGT en su artículo 114, siendo buen exponente la declaración de la Sentencias del Tribunal Supremo de 12 de marzo de 1991. 
b) Dies a quo de la caducidad sancionadora tributaria

El momento inicial del plazo de caducidad, con carácter general, será la fecha de la notificación del acuerdo de incoación el que determine el inicio del cómputo de la caducidad, resultando irrelevante a tales efectos tanto la fecha de registro de salida (art. 211.2 LGT), a diferencia del régimen ordinario administrativo del art. 21.3.a) de la Ley 39/2015, de 1 de octubre, del Procedimiento Administrativo Común de las Administraciones Públicas - LPACAP— ${ }^{40}$. En el ámbito tributario, la eficacia de la incoación se supedita a su notificación y desde la fecha de ésta y no la de la propia resolución $n^{41}$. De igual modo, el plazo para su resolución terminará no con el mero dictado de la resolución sino con su notificación -o al menos un intento-, dentro del plazo total de seis meses, a diferencia del régimen administrativo común ${ }^{42}$.

c) Relación entre caducidad sancionadora tributaria y prescripción de la infracción tributaria

Producida la caducidad, y aún cuando para arribar al vencimiento del plazo general de prescripción del ilícito tributario detectado resten todavía muchos meses o incluso años, exigencias inherentes al principio de la seguridad jurídica han de evitar que aquella Administración pueda, a su antojo y conveniencia, y quizás con inconfesables fines espurios, demorar indefinidamente la efectiva iniciación del procedimiento sancionador, imponiendo así sobre el presunto responsable una velada amenaza de iniciar en su contra el expediente sancionador tributario que, en realidad, nada constitucionalmente legítimo puede comportar ${ }^{43}$. De ahí que, con rigu-

40 Con anterioridad regulado en los arts. 6.2 y 20.6 del derogado RD 1398/1993.

${ }^{41}$ A diferencia del modelo de procedimiento administrativo sancionador común que sentenció la STS 27.4.2004; Modelos distintos al común, y similares al tributario, los encontramos en el art. 52.1.a RD Lg. 5/2000, de 4 de agosto, en materia de infracciones del orden social; o en el art. 10.1 del RD 320/1994, en materia sancionadora de tráfico.

${ }^{42}$ Buen ejemplo de la innecesariedad de notificación para entender cumplido en plazo el procedimiento, es la STS 2.04.2004, aunque la generalidad de la jurisprudencia viene exigiendo que para determinar el día final en el cómputo de la caducidad del procedimiento, haya que estar a la fecha de notificación al interesado del acuerdo sancionador - dentro de cuyo plazo de caducidad debe estar notificada(por todas, STS 3.12.2003).

${ }^{43}$ Desde otro punto de vista, LAMOCA PÉREZ, considera que la LGT regula una especie de prescripción encubierta de las infracciones, a través de instrumentos jurídicos que impedirían el inicio del procedimiento sancionador, instrumentos que se traducen en la utilización de la caducidad para recortar el plazo de vigencia del 
roso criterio, el legislador haya subordinado la incoación del expediente sancionador al transcurso de unos pocos meses, con absoluta independencia del tiempo que reste para cumplimentar el plazo de prescripción de la infracción advertida, en aquellos supuestos, precisamente, en que, como consecuencia de la tramitación de otro diferente procedimiento tributario, la Administración haya tenido cumplida constancia de la existencia de dicha concreta infracción y de la identidad del presunto responsable de su comisión.

Así las cosas, tanto en los casos previstos en los artículos 209.2. ${ }^{\circ}$ - sin perjuicio de lo que se dirá respecto del plazo para las sanciones no pecuniarias-y $211.4 .^{\circ}$ de la LGT, se opta por recortar los plazos de prescripción a través de los términos de caducidad. Según el derecho común, en la caducidad un derecho debe ejercitarse en el plazo concedido al efecto, de tal forma que transcurrido dicho plazo se produce la preclusión del mismo. En la prescripción, un derecho se extingue por su inactividad. En la LGT, para algún autor ${ }^{44}$, la caducidad se declara respecto del procedimiento, pero produce efectos materialmente prescriptivos respecto de la acción ${ }^{45}$. La consecuencia

derecho de la Administración a exigir responsabilidades derivadas de la comisión de infracciones tributarias, en suma, el plazo de prescripción. Estaríamos no sólo en presencia de una prescripción encubierta de las infracciones sino de una prescripción de todas las consecuencias que de su declaración se derivasen. LAMOCA PÉREZ, C.: Infracciones..., op. cit., pág. 214.

${ }^{44}$ Para LAMOCA «a través del artículo 209.2. ${ }^{\circ}$ LGT se regula una especie de prescripción encubierta de las infracciones, a través de instrumentos jurídicos que impiden el inicio mismo del procedimiento sancionador. Instrumentos jurídicos que se traducen en la utilización de la caducidad para recortar el plazo de vigencia del derecho de la administración a exigir responsabilidades derivadas de la comisión de infracciones tributarias, en suma, el plazo de prescripción. ... La LGT opta en ambos casos (209.2. ${ }^{\circ}$ y 211.4 LGT) por recortar los plazos de prescripción a través de plazos de caducidad...En la LGT la caducidad se declara respecto del procedimiento pero produce efectos materialmente prescriptitos respecto de la acción». LAMOCA PÉREZ, C.: Infracciones..., op. cit., págs. 466 y 467; Para MESTRE GARCÍA todo apunta a que se trata de un plazo de caducidad, pues resulta evidente que no es un plazo de prescripción porque la prescripción de la acción administrativa para imponer sanciones cuenta en la Ley con una regulación específica en el título que regula la potestad sancionadora...Aunque el art. 209.2 LGT parece tener la naturaleza de un plazo de caducidad, bien entendido que la caducidad no lo es del procedimiento (que no se ha iniciado aún) sino de la acción administrativa para iniciar el procedimiento sancionador... Se advierte que el régimen de la prescripción queda claramente mitigado en materia sancionadora..MESTRE GARCÍA, E. y CERVANTES SÁNCHEZ-RODRIGO, C.J.: Guía de infracciones..., op. cit., págs. 264 y 285.

${ }^{45}$ La prescripción se relaciona con el ejercicio de la potestad administrativa, la caducidad con el procedimiento en que aquélla se formaliza. Sin embargo, cuando se habla de caducidad de la acción, en realidad se trata de un supuesto de prescripción especial en el cual se fija un plazo diferente, más corte, ya que su dies a quo es el conocimiento que tiene la Administración sobre aquellos hechos ilícitos y no 
de que no pueda iniciarse un procedimiento nuevo por caducidad del anterior hace que, sin declarar la prescripción de la acción material, se consigan los mismos efectos, si bien en un plazo considerablemente más corto, así de cuatro años a los tres o seis meses según se trate de incoación o terminación del procedimiento sancionador.

d) Caducidad en la terminación del procedimiento sancionador tributario

La caducidad en la terminación del procedimiento del artículo 211.4 de la LGT, o perención ${ }^{46}$, produce efectos meramente procedimentales, afectando sólo al procedimiento, y no produciendo directamente y por sí sola la extinción de derecho o facultad alguno ${ }^{47}$.

\section{CADUCIDAD EN LA INICIACIÓN DEL PROCEDIMIENTO SANCIONADOR TRIBUTARIO}

\section{III.1. Naturaleza jurídica}

Si durante el plazo de tres meses, previsto en el artículo 209.2 LGT, no se inicia el procedimiento sancionador parece decaer ${ }^{48}$ la

cuando éstos se realicen. REBOLLO PUIG, M.: Potestad..., op. cit., págs. 792 a 794; aunque la jurisprudencia acostumbra a distinguir entre caducidad de la acción y prescripción, así la STS de 19 de mayo de 1993, estima que «la caducidad de la acción es un concepto procesal, según el cual, el transcurso del tiempo fijado en la norma sin que se ejercite la acción, extingue ésta. La caducidad de la acción en las infracciones administrativas opera una vez haya finalizado las diligencias de esclarecimiento de los hechos que puedan constituir infracciones administrativas, siempre que el órgano administrativo competente no inicie el oportuno expediente sancionador»; ANEIROS PEREIRA, J.: Las sanciones..., op. cit., pág. 204; AGUADO I CUDOLÀ, V.: Prescripción ..., op. cit., pág. 153.

${ }_{46}$ Así la SAN de 26 de noviembre de 2009 (FJ 4. ${ }^{\circ}$ ) «la ineficacia del acto de notificación examinado nos conduce a ratificar la caducidad declarada, con la consiguiente perención y decaimiento de la potestad sancionadora».

47 AGUADO I CUDOLÀ, V.: Prescripción..., op. cit., pág. 47; También de ese parecer MAGRANER MORENO, F.J. y MARTÍN LÓPEZ. J.: «El límite temporal...», op. cit.., $Q F$, núm. 20, 2003, pág. 13; FERREIRO LAPATZA, J.J.: Curso de Derecho..., op. cit., 2006, pág. 563.

${ }_{48}$ En definitiva, si una vez conocidos los hechos objetivamente constitutivos de una infracción tributaria la Administración no formula cargos respecto al contribuyente que los ha realizado, transcurridos tres meses desde la notificación de la resolución por la que se pone fin al procedimiento de aplicación, la ley presume que, pese a la regularización de que haya podido ser objeto, el interesado actuó con la diligencia debida. En consecuencia, al faltar el elemento subjetivo del tipo, no existe responsabilidad infractora que, vencido dicho plazo, justifique el inicio de un proce- 
posibilidad de sancionar las infracciones que se hayan puesto de manifiesto con lo actuado en los procedimientos iniciados por declaración, verificación de datos, comprobación o inspección.

Enfatizamos la postura de algunos autores ${ }^{49}$, de que se trata de un plazo de caducidad de la acción dentro del mencionado plazo de prescripción, por no resultar oportuno introducir esta figura en el ámbito de la potestad sancionadora, ya que no se trata de una situación claudicante o en la que se exija que se aclare una situación jurídica. Por ello, estos autores prefieren entender que estamos ante un supuesto de prescripción especial que tiene un plazo más corto porque su «dies a quo» coincide con el momento en el que la Administración tiene conocimiento de la comisión de los hechos ilícitos y no con el del momento en el que éstos se realicen.

Necesario resulta mentar la opinión de Falcón y Tella ${ }^{50}$, para quien la fijación de este plazo implica una decisión presunta de no sancionar, que ha de considerarse firme, y que, por ello, no puede revisarse utilizando los procedimientos especiales de los artículos 218 y 219 de la Ley 58/2003 (anteriores artículos 153 y 154 de la LGT 1963), esto es, la única posibilidad sería la revisión del acta, como si se tratara de un acto anulable.

Este mecanismo trata de garantizar la seguridad jurídica del obligado tributario, cuando, tras una primera valoración del inspector actuario sobre la procedencia de iniciar el procedimiento sancionador, se imposibilita al Inspector-Jefe a autorizar el comienzo del procedimiento, por haber transcurrido esos plazos. Ahora bien, no hay que olvidar que precisamente garantizar la seguridad jurídica es

dimiento sancionador. IGLESIAS CAPELLAS, J.: «La caducidad del procedimiento sancionador tributario», Impuestos, núm. 8, Sección Doctrina, Quincena del 16 al 30 Abr. 2008, Año XXIV, Ref. D-486, pág. 286, tomo I

49 Siguiendo a GARBERÍ LLOBREGAT, AGUADO I CUDOLÁ, V.: Prescripción..., op. cit., pág. 153; MARCOS CARDONA, M.: El procedimiento..., op. cit., págs. 86 y 87 .

50 Así «en el caso que nos ocupa no se trata, sin embargo, de la terminación de procedimiento alguno, sino de la imposibilidad de iniciarlo, lo que sólo se explica, según el autor, si partimos de la existencia de un acto administrativo presunto declarativo de la inexistencia de infracción. Téngase en cuenta, además, que en realidad esto ya era más o menos así en el sistema tradicional de procedimiento único, liquidatorio y sancionador, pues una vez adquirida firmeza, impedía sancionar, o más precisamente suponía una declaración administrativa de la inexistencia cíe responsabilidad, en principio inmodificable sin seguirlos procedimientos especiales de revisión de oficio. De lo que se trata, por tanto, es de evitar que la separación de procedimientos operada por la Ley $1 / 1998$ perjudique a los contribuyentes, prolongando el plazo durante el que está abierta la posibilidad de sancionar». FALCÓN Y TELLA, R.: «La nueva regulación del régimen sancionador tributario: una ocasión perdida», $Q F$, núm. 21, 1998, pág. 7. 
también la finalidad de la prescripción, por lo que, tras realizar esta afirmación, cabe preguntarse qué sentido tiene el plazo de prescripción de cuatro años de la acción para sancionar si, con independencia del momento en el que nos encontremos, tras la notificación de la liquidación existe una limitación temporal para el inicio del procedimiento sancionador.

Con anterioridad a la Ley 58/2003, de 17 de diciembre, General Tributaria, este sistema parecía estar sólo pensado para los supuestos en los que en el acta incoada existiese una declaración contraria a la iniciación del expediente sancionador ${ }^{51}$.

Con la ampliación del plazo de uno a tres meses, parecía lógico pensar que se adaptaba en mayor medida a la realidad, ya que el de un mes resultaba claramente insuficiente. También resultaba rele-

51 Se llegó a esta interpretación, en primer lugar, porque el artículo 49.2 del Real Decreto 939/1986, de 25 de abril, por el que se aprueba el Reglamento General de la Inspección de los Tributos. - RGIT - establecía, en su letra j), que uno de los requisitos de las actas de inspección es que, en su caso, se hiciera constar la ausencia de motivos para proceder a la apertura del procedimiento sancionador, en el supuesto de que el actuario no considere necesaria su iniciación, y según parecía, sólo a estos efectos, en el siguiente párrafo, limitaba la iniciación del procedimiento sancionador si no se había iniciado en los plazos previstos en el artículo 60.2 de esa derogada norma. Esto parecía lógico, ya que si en el acta se recogía expresamente que no se habían encontrado motivos para iniciar procedimiento sancionador, la seguridad jurídica demandaba que si el Inspector-Jefe entendía que sí que los había, este cambio de criterio tenía que ser conocido en un plazo breve.

Ahora bien, el sentir mayoritario de la doctrina era que esta limitación temporal debía afectar a la iniciación del procedimiento sancionador tanto si en el acta se ponían de manifiesto motivos para incoar el procedimiento sancionador como si esto no era así, ya que para ellos, el sentido de esta limitación temporal se encontraba en la inmediatez y disuasión que debían presidir la persecución de toda infracción y la imposición de la sanción oportuna como respuesta a la comisión del ilícito tributario, ya que de otro modo, como señalaba SÁNCHEZ PEDROCHE, «... no sólo se habría interrumpido al cómputo de la prescripción de la infracción con las actuaciones administrativas tendentes al descubrimiento de la posible deuda tributaria (...), sino que se dejaría en manos de la Administración una libertad omnímoda de iniciar el procedimiento sancionador modulando con ello ulteriores interrupciones de la prescripción». En nuestra opinión, precisamente una de las funciones de la prescripción es conseguir que la multa cumpla con su función preventiva y represiva, así como sancionar conductas en un plazo razonable frente al interés colectivo que demanda que las mismas se castiguen, por lo que no se considera que sea preciso otro plazo que garantice los mismos objetivos.

En este sentido CABALLERO SÁNCHEZ critica esta caducidad de la acción sancionadora, porque se superpone con la prescripción, resultando excesiva la combinación de ambos mecanismos, y además, porque los Tribunales no suelen entender bien su significado a la hora de su aplicación. CABALLERO SÁNCHEZ, R.: «Las formas de extinción de la responsabilidad administrativa», $J A$, número extraordinario 2001 sobre Infracciones, sanciones y procedimiento administrativo sancionador, pág. 145. 
vante que el cómputo del inicio del plazo de tres meses fuera en la fecha en que se hubiese notificado o se entendiese notificada la correspondiente liquidación. En este sentido, resultó loable la elección de este criterio, puesto que incrementaron las garantías del administrado, aunque llama la atención el que, en este punto, el legislador se desmarcase de la que venía siendo la regla general en los procedimientos tributarios, que, como es sabido, opta por la fecha en la que se dicta la liquidación.

Este mismo plazo se ha mantenido en el actual artículo 209.2. ${ }^{\circ}$ de la Ley 58/2003, General Tributaria, así como se ha adoptado idéntico criterio de cómputo del plazo de caducidad. De otro lado, se ha ampliado $^{52}$ el número de procedimientos a los que le resulta de aplicación, aunque continúan existiendo procedimientos en los que no resulta de aplicación dicha caducidad, sino el plazo general de prescripción de la responsabilidad de cuatro años, como ya se indicó. Por último, no podemos considerar vigente la opinión ${ }^{53}$ de que el

${ }^{52}$ No obstante la redacción literal del precepto en este caso no es muy clara y perfectamente se podría entender la postura contraria, así cualquier infracción tanto derivada de un procedimiento de verificación, de comprobación o de inspección, así como cualquier infracción cometida en su desarrollo, tienen como límite para el inicio del expediente sancionador el plazo de tres meses desde que finaliza el procedimiento principal de que se trate. MANCHO ROJO, R.: El régimen sancionador tributario y su aplicación a las haciendas locales, Fundación Asesores Locales,Málaga, 2005, pág. 153.

${ }_{53}$ En esta línea, se ha manifestado JUAN LOZANO, A.M., en «El plazo para el inicio...», op. cit.; AGUADO y CUDOLÁ, V., se ha preguntado si es oportuno o no establecer plazos de prescripción de la acción en relación con el ejercicio de la potestad administrativa sancionadora. Al respecto, tras comprobar que en la LRJ-PAC [hoy LPACAP] no se encuentra ninguna alusión a la caducidad del derecho a perseguir infracciones, sino exclusivamente a la prescripción y a la caducidad del procedimiento o perención, considera, siguiendo a GARBERÍ LLOBREGAT, que «el ejercicio de la potestad sancionadora, por su propia configuración, responde a plazos de prescripción y no de caducidad. No estamos ante una situación claudicante en la que el ordenamiento jurídico requiera que se aclare la situación, para que se produzcan unas situaciones jurídicas firmes e inatacables, sino que tal y como hemos dicho se trata de sancionar conductas dentro de un plazo razonable y no en la configuración o modificación de una situación jurídica». AGUADO I CUDOLÀ, V.: Prescripción..., op. cit., págs. 152 y 153; Estos autores son los defensores de la teoría de la «actio nata», según la cual el «dies a quo» del plazo de prescripción de la infracción no se lija tomando como punto de referencia el día en el que la infracción se ha consumado sino el momento en el que puede iniciarse el procedimiento sancionador. Continúa señalando que «... en el caso que nos ocupa no se trata, sin embargo, de la terminación de procedimiento alguno, sino de la imposibilidad de iniciarlo, lo que sólo se explica si partimos de la existencia de un acto administrativo presunto declarativo de la inexistencia de infracción. Téngase en cuenta, además, que en realidad esto ya era más o menos así en el sistema tradicional de procedimiento único, liquidatorio y sancionador, pues una vez adquirida firmeza, impedía sancionar, o más precisamente suponía una declaración administrativa de la inexistencia de res- 
plazo de tres meses, en supuestos de procedimientos de inspección sea únicamente aplicable en los casos en que se haya hecho constar la «la inexistencia, en opinión del actuario, de indicios de la comisión de infracciones tributarias», considerando que, ahora, el artículo 153.g) LGT ya no exige que se proceda a la apertura del procedimiento sancionador. Sin embargo, aunque el artículo 209.2. ${ }^{\circ}$ hable que «los procedimientos sancionadores que se incoen como consecuencia de un procedimiento iniciado mediante.... inspección...», debemos entender que dicho supuesto lo será tanto para el caso en que se haya transcrito en el acta de inspección la existencia, como la inexistencia, de indicios de comisión de infracciones tributarias, operando en ambos casos.

\section{III.2. Acuerdo incoatorio del procedimiento sancionador tributario}

Conforme al artículo 209.1 de la LGT, «el procedimiento sancionador en materia tributaria se iniciará siempre ${ }^{54}$ de oficio, mediante la notificación del acuerdo del órgano competente». Dicho acuerdo de incoación ${ }^{55}$, en el resto de los procedimientos de aplicación de los tributos que no sean los del artículo 209.2 de la LGT $^{56}$, deberá ser

ponsabilidad, en principio inmodificable sin seguirlos procedimientos especiales de revisión de oficio. De lo que se trata, por tanto, es de evitar míe la separación de procedimientos operada por la Ley perjudique a los contribuyentes, prolongando el plazo durante el que está abierta la posibilidad de sancionar». FALCÓN Y TELLA, R.: «La nueva regulación...», op. cit.

${ }^{54}$ El término siempre se omite en la redacción del RGRST.

55 En defecto de norma expresa en materia tributaria, no parece que exista inconveniente en admitir la práctica de las actuaciones previas, contempladas en el art. 12 del RD 1398/1993 [hoy art. 55.2 LPACAP], siempre que estuvieran debidamente justificadas. En cualquier caso, estas actuaciones no resultarán necesarias razonablemente cuando haya mediado previamente un procedimiento de aplicación de los tributos...El problema de estas actuaciones radicará en que no interrumpen el plazo máximo de tres meses que recoge el art. 209.2 LGT. HERRERO DE EGAÑA Y ESPINOSA DE LOS MONTEROS, J.M. (coord.): Comentarios a la Nueva Ley General Tributaria, Vol. II, Aranzadi, Pamplona, 2004, Vol. II, pág. 1400.

${ }^{56}$ Con ello, se instaura una especie de doble contador, que va discurriendo de forma paralela, uno con la prescripción, en el que se tendrán en cuenta sus causas de interrupción y el reinicio del cómputo desde cero cada vez que se produzca una de ellas, y otro con la caducidad, en el que también se deberán tener en cuenta sus limitados supuestos en los que se suspende el cómputo de la misma y los momentos en los que se procede a reanudar el citado cómputo en el mismo punto en el que se encontraba cuando acaeció la causa de suspensión de la misma. De esta forma, uno de los dos contadores llegará a su punto final, cuatro años en el caso de la prescripción o seis en el de la caducidad, antes que el otro, y en el momento en que se complete cualquiera de ellos, se habrá extinguido la posibilidad de que la Administra- 
adoptado dentro del plazo de prescripción de cuatro años desde que se cometiere la infracción. A esta solución llegó el TEAC en Resolución de 30 de marzo de 2012, admitiendo que no procede la aplicación del plazo de tres meses previsto en el artículo 209.2 LGT en el supuesto de sanción por infracción consistente en no atender a requerimientos de información tributaria sobre terceros, al no derivar el procedimiento sancionador de un procedimiento iniciado mediante declaración o de un procedimiento de verificación de datos, comprobación o inspección y que, por tanto, llevan aparejada la notificación de una liquidación o resolución: aplicación del plazo de prescripción.

Por otro lado, especial interés ha de ponerse en la regulación del régimen jurídico del acto de la Administración tributaria por medio del cual se produce la iniciación del procedimiento sancionador, acto de trascendental importancia, que constituye el presupuesto formal básico para todo adecuado ejercicio de la potestad sancionadora de la Administración, y también para la incoación del correspondiente procedimiento, garantizado constitucionalmente y por el artículo 207 de la LGT y el artículo 53 de la LPA$\mathrm{CAP}^{57}$, de modo que permita, desde ese instante, ejercitar el derecho de defensa de las personas presuntamente responsables de las infracciones tributarias, posibilitando igualmente la posterior emisión, en su caso, tras los trámites oportunos, de una decisión definitiva respetuosa con el derecho a la presunción de inocencia de los sujetos imputados.

El acuerdo de iniciación es también el acto que contiene la imputación provisional, a través de cuya notificación se hace posible la efectividad del derecho del administrado a su conocimiento previo, dando lugar a que, por éste se adopten las posturas defensivas de todo tipo que se consideren oportunas en orden a resistirla, pudiendo incluso aquietarse a la imputación ${ }^{58}$.

Con el referido acuerdo se hace efectivo el derecho de los interesados a promover la recusación o la declaración de incompetencia de los órganos instructor y decisor del expediente, posibilitando, de este

ción tributaria determine la deuda tributaria mediante la oportuna liquidación en el caso concreto o de que imponga la sanción tributaria correspondiente. ALONSO ARCE, I.: «La caducidad como límite a las interrupciones de la prescripción», JT, núm. 9, 2005, pág. 1 .

${ }^{57}$ Con anterioridad recogida en el art. 134 de la LRJPAC.

58 GARBERÍ LLOBREGAT, J. et alii: Procedimiento Sancionador..., op. cit. T. II, pág. 1.363 .

(c) UNED. Revista de Derecho UNED, núm. 23, 2018 
modo, una instrucción y resolución del procedimiento a cargo de órganos imparciales y competentes ${ }^{59}$.

Equivale, pues, dicho acuerdo a un trasunto de lo que en materia procesal penal constituyen la querella (art. 277 LECrim $^{60}$ ) y el auto de procesamiento (art. 384 LECrim), asemejándose más a este ultimo en tanto que el acuerdo de iniciación del expediente administrativo sancionador encierra una actuación emanada de una autoridad pública por medio de la cual, y ante la apreciación de indicios racionales indicativos de haberse cometido una infracción tributaria, se considera imputado a un sujeto al que se atribuye la presunta responsabilidad en la comisión de los hechos reputados ilícitos.

Todo procedimiento sancionador tributario exige del acuerdo de mero trámite ${ }^{61}$ que contiene el escrito de la incoación. A tal fin, el apartado tercero, letra a), del artículo 208 LGT garantiza, como derecho del afectado por este procedimiento, " el ser notificado ${ }^{62}$ de los hechos que se le imputen, de las infracciones que tales hechos puedan constituir y de las sanciones que, en su caso, se le pudieran imponer, así como de la identidad del instructor, de la autoridad competente para imponer la sanción y de la norma que atribuya tal competencia.»

El acto por el que se acuerda el inicio del procedimiento podrá ser recurrido en caso de vulneración de derechos o garantías fundamentales, de otro modo, y dado su carácter de acto de trámite, sus defectos o vicios deberán denunciarse con ocasión del recurso que proceda contra el acto que ponga a fin al procedimiento sancionador $^{63}$, ello podría tener incidencia en el cómputo del plazo de terminación.

59 ANEIROS PEREIRA, J.: Las sanciones..., op. cit., págs. 205 a 208.

${ }^{60}$ Real decreto de 14 de septiembre de 1882 por el que se aprueba la Ley de Enjuiciamiento Criminal.

${ }^{61}$ STSJ de Murcia de 19 de septiembre de 2001; dicho acuerdo supone el inicio del plazo de seis meses para resolver. BAYONA JIMÉNEZ, J.J.: La caducidad..., op. cit., pág. 158 .

${ }^{62}$ La STSJ de Andalucía de 11 de enero de 2002 sentencia que no es válida la notificación edictal; Las SsTSJ de Castilla y León de 25 de febrero de 2003 y de Valencia de 19 de diciembre de 2002, afirman la nulidad de la sanción impuesta por la falta de notificación del acuerdo de inicio.

${ }_{63}$ ANEIROS PEREIRA, J.: Las sanciones..., op. cit., pág. 213; DE MIGUEL CANUTO, E.: «El procedimiento para sancionar las infracciones graves por la Inspección de Tributos: algunos aspectos», TF, núm. 98, 1998, pág. 63; GARCÍA IZQUIERDO, S.: "Comentarios al nuevo procedimiento sancionador tributario», RCT-CEF, núm. 190, 1999, pág. 11; COBO OLVERA, T.: El procedimiento sancionador tipo, Bosch, Barcelona, 1999, pág. 88; GONZÁLEZ PÉREZ, J.: Comentarios..., op. cit., pág. 519 . 
Dicho acto de incoación puede incorporar, incluso, la propuesta de imposición de sanción ${ }^{64}$ siempre que al tiempo de iniciarse el expediente sancionador se encontrasen en poder del órgano competente todos los elementos que permitan formularla (art. 210.5. ${ }^{\circ}$ LGT, art. 23.6. ${ }^{\circ}$ RGRST).

Con el referido acto administrativo se posibilita ciertamente el conocimiento previo de la imputación provisional por parte del inculpado, el eficaz ejercicio de su derecho a promover la recusación, la declaración de incompetencia, y que, a través de su notificación, se hace también efectivo el derecho de defensa de los presuntos responsables, de modo que el procedimiento sancionador en que se haya omitido el necesario acuerdo sobre su incoación no es tal, no es procedimiento alguno capaz de merecer jurídicamente tal calificativo, sino un conjunto inconexo de tramites inquisitivos, contrarios a los mas elementales derechos fundamentales de los administrados. La falta de emisión del acuerdo constituye, pues, una causa de nulidad de pleno derecho de los trámites que puedan sucederse posteriormente al momento en que debió ser dictado, amparada por igual en las letras a) y e) del art. 217.1 LGT ${ }^{65}$.

El apartado primero del artículo 22 del Real Decreto 2063/2004, de 15 de octubre, por el que se aprueba el Reglamento general del régimen sancionador tributario, se intitula de la iniciación del procedimiento sancionador, y reglamenta el contenido mínimo necesario $^{66}$ del acto de incoación, cuya irregularidad podría comportar la anulación de las actuaciones, siempre que ocasionase indefensión.

${ }^{64}$ GARBERÍ LLOBREGAT, J.: define este procedimiento como «sancionador tributario abreviado».Procedimiento sancionador..., op. cit. T. I, pág. 1.065.

65 Así lo ha estimado también la jurisprudencia del Tribunal Supremo, en las SsTS de 26 de abril de 1985, de 19 de octubre de 1987, o la STSJ Andalucía (Sevilla) de 29 de octubre de 1987.

66 Contendrá necesariamente las siguientes menciones: a) Identificación de la persona o entidad presuntamente responsable. b) Conducta que motiva la incoación del procedimiento, su posible calificación y las sanciones que pudieran corresponder. c) Órgano competente para la resolución del procedimiento e identificación del instructor. d) Indicación del derecho a formular alegaciones y a la audiencia en el procedimiento, así como del momento y plazos para su ejercicio; La posibilidad de dirigir hoy el procedimiento contra varias personas resulta clara de lo dispuesto en el art. 181.3 LGT, aunque sea indiferente determinar el grado de responsabilidad, ya que, en todo caso, ésta será solidaria frente a la Administración. ANEIROS PEREIRA, J.: Las sanciones..., op. cit., pág. 206; El RGRST no ha previsto plazo alguno para subsanar los defectos de contenido de este acuerdo ni las consecuencias de su contenido o notificación defectuosa, aunque, a nuestro juicio, será difícil que por defectos de contenido-no así de notificación-pueda invalidarse la sanción si el obligado tributario no ha visto mermados sus derechos de defensa. 
Además, en los casos de procedimientos sancionadores tramitados de modo separado al de inspección, según el artículo 25.1. ${ }^{\circ}$ in fine del RGRST por remisión del artículo 22.3.a) del RGRGST, " en todo caso, el inicio del procedimiento sancionador requerirá autorización previa del inspector-jefe ${ }^{67}$, que podrá ser concedida en cualquier momento del procedimiento de comprobación e investigación o, una vez finalizado éste, antes del transcurso del plazo máximo establecido en el artículo 209 de la Ley 58/2003, de 17 de diciembre, General Tributaria.» Para estos casos, no sólo se exige acuerdo de incoación, sino también de previa autorización ${ }^{68}$, sin la cual se podría originar una discutible la nulidad del procedimiento incoado.

\section{III.3. Notificación del acuerdo incoatorio del procedimiento sancionador tributario}

Resuelto dicho acto administrativo en cualquier momento del plazo de prescripción, deberá ser notificado, y desde dicho instante el único plazo de caducidad que le sujetará será el de seis meses para la notificación de la terminación del procedimiento sancionador tributario, previsto en el artículo 211.2.1. ${ }^{\circ}$ de la LGT, transcurrido el cual, sin que haya notificado la resolución alguna que ponga fin a dicho procedimiento, la caducidad impedirá la iniciación de un nuevo procedimiento sancionador.

Expuesto lo anterior, debemos precisar que el plazo de caducidad para la incoación del procedimiento sancionador, que expresa el artículo 209.2. ${ }^{\circ}$, exige, para que principie su cómputo — dies a $q u o-$, de su puesta en conocimiento ${ }^{69}$ al interesado toda resolu-

67 Para ESCRIBANO LÓPEZ la nota decisiva para la iniciación será que se indique en el Acta, mientras que para MUÑ́́Z BAÑOS el funcionario que instruye el expediente administrativo ordinario es quien tiene competencias para incoar el procedimiento sancionador, y finalmente para ANEIROS se trata de un supuesto de inicio del procedimiento por orden de un superior jerárquico, previa propuesta del actuario, puesto que éste por si sólo nunca podrá iniciar el expediente. ANEIROS PEREIRA, J.: Las sanciones..., op. cit., págs. 199 y 200; La STSJ de Madrid de 19 de septiembre de 2008 (FJ 4. ${ }^{\circ}$ ) diferencia, como actos diversos, el de incoación y el de autorización.

${ }^{68}$ No supone interrupción alguna la simple autorización del Inspector Jefe para iniciar el procedimiento sancionador. MANCHO ROJO,R.: El régimen..., op. cit., pág. 43.

69 Por remisión del art. 208.4 de la LGT, específicamente la notificación del acto se realizará conforme a los arts. 109 a 112 LGT y 114 a 115 ter del RD 1065/2007, de 27 de julio, sin perjuicio de que, supletoriamente, se apliquen las disposiciones administrativas generales. De este modo, el régimen de notificaciones del procedimiento sancionador tributario será el previsto en las normas administrativas gene- 
ción o liquidación que ponga fin al procedimiento concreto de aplicación de tributos a que dicho apartado refiere. La notificación ${ }^{70}$ cumple fundamentalmente dos funciones, una como requisito que condiciona la eficacia del acto que comunica, y otra como garantía jurídica, en cuanto hace posible que los interesados conozcan los actos de la Administración que afectan a sus derechos e intereses legítimos, de modo que su ausencia tendrá efectos cuando implique perjuicios para el administrado, pero no cuando aquélla le beneficie $^{71}$. Conforme resolvió la Resolución del TEAC de 23 de junio

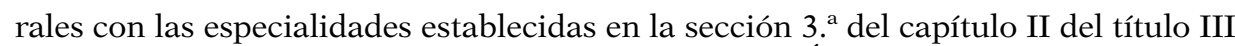
de la Ley General Tributaria (art. 109 LGT). GARBERÍ considera que «el ultimo de los apartados del art. 208 LGT contiene una remisión general a lo establecido en los arts. 109 a 112 LGT, formalizando, así, una doble remisión: de una parte la que acabe de señalarse, y por otra la remisión que el citado art. 109 LGT efectúa a favor de las normas administrativas generales (esto es, a los arts. 58 y 59 LRJPAC) [hoy arts. 40-44 LPACAP], sin perjuicio de las especialidades previstas en los restantes art. 110 a 112 LGT. (GARBERÍ LLOBREGAT, J. et alii: Procedimiento sancionador..., T. I, op. cit., pág. 1091); Basta el transcurso del plazo establecido sin que se haya producido una determinada actuación administrativa, con independencia de que exista una voluntad procedimental,... sin necesidad de requerimiento previo. AGUADO I CUDOLÀ, V.: Prescripción..., op. cit., pág. 34; Dicha notificación puede ser expresa, pero también presunta en cuyo caso el plazo de tres meses se computa desde que tal resolución se entiende producida. Lo expuesto no debe confundirse con el supuesto contemplado en el artículo 104.2 LGT, cuya eficacia evita que se produzca la caducidad en los procedimientos generales de aplicación de los tributos o los efectos previstos en el art. 150 de la LGT para los procedimientos sancionadores. El art. 104.2 LGT se limita a establecer la presunción de finalización del plazo de duración del expediente, pero no establece una presunción de notificación cierta al contribuyente. MANCHO ROJO, R.: El régimen sancionador..., op. cit., pág. 154; en igual sentido, FALCÓN Y TELLA, para quien, críticamente, debería volverse al plazo de un año para iniciar el procedimiento, y mientras ello no ocurra puede resultar aconsejable renunciar al procedimiento sancionador separado, conforme a lo previsto en el art. 208 de la nueva Ley General Tributaria, de forma que siempre sea posible, en caso de sanción, recurrir también la liquidación. FALCÓN Y TELLA, R.: «El plazo para iniciar el expediente sancionador», $Q F$, núm. 10, 2007.

${ }^{70}$ Ampliamente en GARCÍA NOVOA, C.: Las Notificaciones Tributarias. Aranzadi, Pamplona, 2001, pág. 117.

71 Así la STS de 17 de noviembre de 1980, manifiesta que «de la falta de notificación no se derivarían más que los efectos previstos en la Ley y siempre precisamente en beneficio de los interesados»; Igualmente, GARCÍA DE ENTERRÍA, E. y FERNÁNDEZ RODRÍGUEZ, T.R.: Curso..., op. cit., vol. I, págs. 576 y ss.; La notificación en el ámbito del Derecho administrativo se viene entendiendo tradicionalmente como una condición o requisito de la eficacia de los actos administrativos (art. 57.2 LRJPAC) [hoy 39.2 LPACAP]...Cabe señalar que la notificación del acto como requisito para que se produzca la interrupción el procedimiento es consecuencia de la imposibilidad que la Administración pueda disponer libremente del régimen de producción de la prescripción y la caducidad que rige en el Derecho administrativo...Es precisamente la exteriorización del acto a través de la notificación la que garantiza que la prescripción y la caducidad en el Derecho administrativo no queden al arbitrio de una de las partes. AGUADO I CUDOLÀ, V.: Prescripción...., op. cit., pág. 39; La regla especial del art. 104.2 de la LGT no resulta de aplicación

(C) UNED. Revista de Derecho UNED, núm. 23, 2018 
de 2004, "hasta su notificación (entendemos del acto de incoación) se computa el plazo máximo de los tres meses de iniciación del procedimiento sancionador y simultáneamente la fecha de esa notificación determina el inicio del plazo de duración del procedimiento sancionador, interrumpiendo de modo irrecurrible, salvo que se vulnere algún derecho fundamental, la prescripción de la acción para sancionar..»

La Sentencia de la Audiencia Nacional de 8 mayo $2007^{72}$ (recurso núm. 477/2004), aclara que el plazo de tres meses es para notificar el acuerdo de inicio, no bastando que la autorización del Inspector Jefe se produzca dentro del mismo.

en el supuesto de incoación del procedimiento sancionador. ANÍBARRO PÉREZ, S. y SESMA SÁNCHEZ, B.: Infracciones..., op. cit., pág. 229; también en la obra colectiva del Profesor CALVO ORTEGA, R. (dir.): Los nuevos reglamentos..., op. cit., pág. 333; Así las SsTC 54/2003, de 24 de marzo y 145/2004, de 13 de septiembre, y las SsTSJ de Castilla y León de 25 de febrero de 2003, de Castilla-La Mancha de 25 de noviembre de 2003.

${ }^{72}$ En su fundamento séptimo dicha sentencia afirma, tras reproducir la STS 4 julio $2005, \ldots$, que «los términos de la referida Sentencia obligan a la Sala a modificar el criterio que venía manteniendo y, en consecuencia, ... exige que se notifique al sujeto pasivo la iniciación del procedimiento sancionador dentro del plazo de un mes (hoy tres meses) desde que se firmó el acta de conformidad, o en el caso de actas de disconformidad, desde la presentación del escrito de alegaciones, constituyendo la notificación dentro de dicho plazo un requisito inexcusable para la eficacia del correspondiente acto administrativo..., A lo expuesto no obsta la circunstancia de que se emitiera... autorización para el inicio del expediente sancionador al no poder tener los efectos pretendidos, pues no es equivalente al acuerdo de inicio del expediente sancionador, al ser una autorización pro futuro respecto de un obligado tributario que se encuentra sujeto a comprobación y cuyo resultado es aún incierto, máxime teniendo en cuenta que se trata de un acto interno que ni siquiera fue notificado al administrado, constituyendo la notificación un requisito inexcusable para la eficacia del correspondiente acto administrativo»; La Audiencia Nacional que, a partir de su sentencia de 17 noviembre 2005 (FJ 3), viene afirmando que la STS de 4 de julio de 2005 le «obliga a modificar el criterio sostenido» en sentencias anteriores "por imperativos de unidad de doctrina», para pasar a reconocer de forma clara e indubitada que el plazo de un mes es un plazo de caducidad, y que si el inicio del procedimiento sancionador no se ha notificado dentro del citado plazo, no puede ya iniciarse con posterioridad. En este mismo sentido se pronuncian las SsAN de 2 de marzo de 2006, recurso 401/2003, FJ 5; de 4 de mayo de 2006 (FJ 6); de 8 mayo 2006 (FJ 3); de 10 de mayo de 2006 (FJ 3) y 4; y de 25 de mayo de 2006 (FJ 4); Son cita de FALCÓN Y TELLA, R.: «El plazo...», op. cit.; el requisito de la notificación ha sido comentado, al tratar la STS de 29 de septiembre de 2008, por CÁNCIO FERNÁNDEZ, R.C.: «Interpretación unificadora del art. 49.2 j) in fine del Reglamento General de la Inspección de los Tributos (STS de 29 de septiembre de 2008», QF, núm. 1, 2009; Con el transcurso de este plazo no se trata, sin embargo, de la terminación de procedimiento alguno, sino de la imposibilidad de iniciarlo, lo que sólo se explica si partimos de la existencia de un acto administrativo presunto declarativo de la inexistencia de infracción. FALCÓN Y TELLA, R.: "La nueva regulación...», op. cit», $Q F$, núm. 21, 1998. 
Existen diferencias respecto de la regulación anterior, pues en el artículo 29.1 del Real Decreto 1930/1998 se preveían otras formas de iniciación del procedimiento sancionador, como el acuerdo del órgano competente, la orden superior o petición razonada de otros órganos $^{73}$.

El plazo de tres meses para incoar ${ }^{74}$ el procedimiento sancionador también se computa desde que «se entienda notificada ${ }^{75}$ », en el ámbito del procedimiento inspector, la resolución o la liquidación del procedimiento de aplicación de los tributos que expresa el art. 209.2. ${ }^{\circ}$ LGT. Entendemos que tal modo de notificar, también se da en los casos de efectuarse notificación de resolución tributaria —o liquidación-, por vía edictal mediante comparecencia ${ }^{76}$, significando que se produce transcurrido el plazo de 15 días naturales, contados desde el siguiente al de la publicación del anuncio en el correspondiente boletín oficial, sin comparecer en las dependencias, «teniéndole [de este modo] por notificado» y «la notificación se entenderá producida a todos los efectos legales», como modalidad de notificación prevista en el artículo 112 LGT $^{77}$ en caso de que no sea posible efectuar la notificación al interesado ${ }^{78}$, o a su representante, por

73 CALDERÓN GONZÁLEZ, J.M.: «El procedimiento sancionador en la nueva Ley 58/2003, de 17 de diciembre, General Tributaria, y sus Reglamentos de desarrollo. La interrupción de la acción administrativa para sancionar. Efectos del procedimiento tendente a la determinación de la deuda tributaria», Impuestos, núm. 2, Sección Doctrina, quincena del 16 al 31 Ene. 2009, Año XXV, Ref. D-552.

${ }^{74}$ El inicio o dies a quo en el cómputo de los plazos de caducidad en el ejercicio de la potestad administrativa vendrán determinados, en principio, por la normativa que en cada caso establezca estos supuestos. AGUADO I CUDOLÂ, V.: Prescripción..., op. cit., pág. 37; STSJ de Madrid de 24 de abril de 2008 (FJ 5..$^{\circ}$.

${ }^{75}$ La cita como notificación tácita, GARCÍA NOVOA, C.: Las notificaciones..., op. cit., pág. 117.

${ }^{76}$ Recordemos que en este caso no se trata propiamente de una notificación del acto administrativo, sino de una citación para que se comparezca para a su vez ser allí notificado, omitiéndose el texto de la notificación, que ni siquiera reseña un somera indicación del acto a notificar, como realiza el art. 61 de la LRJPAC.

77 Es dudosa la aplicación en el ámbito del procedimiento sancionador el régimen de notificación por comparecencia, especialmente lo dispuesto en el art. 112.3 de la LGT. Evidentemente, la aplicación de dicha regla al ámbito de los expedientes sancionadores permitiría omitir, incluso, el acto de imposición de la sanción, lo cual es inaceptable en virtud del art. 135 de la LRJPAC [hoy art. 53.2 LPACAP] que establece la notificación con uno de los derechos del presunto responsable. ANÍBARRO PÉREZ, S. y SESMA SÁNCHEZ, B. en la obra colectiva del Profesor CALVO ORTEGA, R. (dir.): ..., op. cit., pág. 333.

${ }^{78}$ Hemos de realizar algunas matizaciones, que entendemos resultan de aplicación, siguiendo el tenor del artículo 42 LPACAP. Práctica de las notificaciones en papel. 1. Todas las notificaciones que se practiquen en papel deberán ser puestas a disposición del interesado en la sede electrónica de la Administración u Organismo actuante para que pueda acceder al contenido de las mismas de forma 
causas no imputables a la Administración tributaria, siempre que conste intentada al menos dos veces en el domicilio fiscal, o tras un solo intento cuando el destinatario conste como desconocido ${ }^{79}$ en dicho domicilio o lugar.

Dejamos constancia ${ }^{80}$ que en este procedimiento sancionador no está prevista la regla especial, que rige en el supuesto del artículo 27.1, párrafo segundo RGRST, donde por remisión al artículo 104.2 de la LGT se considera válido el primer intento de notificación en los casos de renuncia a la tramitación separada del procedimiento sancionador, por lo que estimamos, salvo en ese supuesto, que dicha regla no resulta aplicable y que la notificación de dicho acto incoatorio sólo será eficaz si realmente se produce.

Necesario resulta concretar que las liquidaciones - provisionales o definitivas ${ }^{81}$ - deben ser notificadas a los obligados tributarios en

voluntaria. 2. Cuando la notificación se practique en el domicilio del interesado, de no hallarse presente éste en el momento de entregarse la notificación, podrá hacerse cargo de la misma cualquier persona mayor de catorce años que se encuentre en el domicilio y haga constar su identidad. Si nadie se hiciera cargo de la notificación, se hará constar esta circunstancia en el expediente, junto con el día y la hora en que se intentó la notificación, intento que se repetirá por una sola vez y en una hora distinta dentro de los tres días siguientes. En caso de que el primer intento de notificación se haya realizado antes de las quince horas, el segundo intento deberá realizarse después de las quince horas y viceversa, dejando en todo caso al menos un margen de diferencia de tres horas entre ambos intentos de notificación. Si el segundo intento también resultara infructuoso, se procederá en la forma prevista en el artículo 44.

${ }^{79}$ Artículo 43 RD 1829/1999 [téngase en cuenta que quedan derogados cuantos preceptos de esta norma contradigan lo dispuesto en el Real Decreto 1298/2006, de 10 de noviembre, según establece su disposición derogatoria única]. Supuestos de notificaciones con un intento de entrega. No procederá un segundo intento de entrega en los supuestos siguientes: a) Que la notificación sea rehusada o rechazada por el interesado o su representante, debiendo hacer constar esta circunstancia por escrito con su firma, identificación y fecha, en la documentación del empleado del operador postal. b) Que la notificación tenga una dirección incorrecta. c) Que el destinatario de la notificación sea desconocido. d) Que el destinatario de la notificación haya fallecido. e) Cualquier causa de análoga naturaleza a las expresadas, que halla objetivamente improcedente el segundo intento de entrega. En los supuestos previstos anteriormente, el empleado del operador postal hará constar en la documentación correspondiente la causa de la no entrega, fecha y hora de la misma, circunstancias que se habrán de indicar en el aviso de recibo que, en su caso, acompañe a la notificación, aviso en el que dicho empleado del operador postal hará constar su firma y número de identificación.

80 CALDERÓN GONZÁLEZ, J.M.: «El procedimiento sancionador...», op. cit.

81 Puede decirse, ..., que la LGT (art. 209.2) no permite la incoación de un expediente sancionador antes de que se haya producido la liquidación derivada de las actuaciones inspectoras, en cualquiera de sus modalidades, expresa o tácita... Y es lógico que así sea porque de otro modo se estaría incoando un procedimiento sancionador sin contar con el acto de liquidación en el que se contiene la cuota tribu- 
los términos previstos en la sección 3. a del capítulo II del título III de la Ley General Tributaria (art. 102.1..$^{\circ}$ LGT), con los datos que preceptúa el artículo 102.2..$^{\circ}$ LGT. Lo apuntado con anterioridad respecto a las notificaciones de las resoluciones es perfectamente trasladable a este supuesto, con la singularidad de que el contenido del acto la liquidación tiene perfiles propios, debiendo expresar « a) La identificación del obligado tributario. b) Los elementos determinantes de la cuantía de la deuda tributaria. c) La motivación de las mismas cuando no se ajusten a los datos consignados por el obligado tributario o a la aplicación o interpretación de la normativa realizada por el mismo, con expresión de los hechos y elementos esenciales que las originen, así como de los fundamentos de derecho. d) Los medios de impugnación que puedan ser ejercidos, órgano ante el que hayan de presentarse y plazo para su interposición. e) El lugar, plazo y forma en que debe ser satisfecha la deuda tributaria. f) Su carácter de provisional o definitiva» (art. 102.2. ${ }^{\circ}$ LGT). Sin embargo, se omite en la notificación toda alusión a si «el acto debe ser definitivo o no en vía administrativa», que contiene el artículo 40.2. ${ }^{\circ}$ LPACAP, extremo que consideramos debe incorporarse al contenido propio de la notificación.

De este modo, concluimos que el artículo 102.2. ${ }^{\circ}$ LGT, más que expresar el contenido propio de la notificación, contiene los elementos mínimos del acto liquidatorio a notificar. En dicho orden de cosas, y considerando que su régimen de notificaciones es el mismo que el previsto para los actos resolutorios no liquidatorios, ponemos de manifiesto que el régimen de medios impugnatorios aparece incluido en el artículo 102.2. ${ }^{\circ} \mathrm{LGT}$, al igual que se contiene en el artículo 40 LPACAP, por lo que incluirlo, duplicadamente, en la notificación - por mor de los artículos $40.2 .^{\circ}$ y 88.3. ${ }^{\circ}$ LPACAP-, como extremo separado del régimen de recursos del acto que se trata de notificar, supone duplicar esfuerzos, y quizás, incurrir en incongruencias y disfunciones en caso de que «el pie de recursos» discrepara del régimen de recursos propio del acto resolutorio ${ }^{82}$.

taria que le sirve de base y fundamento; acto de liquidación que, como se sabe, no tiene por qué coincidir con la propuesta contenida en el Acta... no nos debe inducir a confusión la redacción de los arts. 22.4 ó 25.2 del Real Decreto 2063/2004, de 15 de octubre..., en los que puede leerse que se iniciarán tantos procedimientos sancionadores como propuestas de liquidación se hayan dictado, pues es evidente que incurren en contradicción con lo previsto en el 209.2 LGT. GANDARIAS CEBRIÁN, A.: « $¿$ Cuando se debe iniciar un procedimiento sancionador tributario dimanante de una inspección?»,QF, núm. 17, 2009.

${ }^{82}$ GARCÍA DE ENTERRÍA considera un error la inclusión del régimen de recursos en el artículo 89.3. ${ }^{\circ}$ LRJPAC [hoy art. 88.3 LPACAP], extremo que cabe aplicar 
En cuanto a las actas, deberán ser firmadas por el funcionario y por el obligado tributario, salvo que el obligado tributario no supiera o no pudiera firmarlas ${ }^{83}$ o en los supuestos de actas de disconformidad (art. 185.2. ${ }^{\circ}$ RD 1065/2007) ${ }^{84}$.

Dictado el acto administrativo incoatorio por el órgano competente, "el procedimiento se iniciará de oficio mediante la notificación del acuerdo del órgano competente... $»^{85}$. Dicha notificación resulta necesaria y será realizada, por mor de lo previsto en el artículo 208.4. ${ }^{\circ}$ LGT $^{86}$, en primer lugar, de conformidad con

también al contenido resolutorio de la liquidación. Así remarca «La LRJPAC [hoy LPACAP] ha traído aquí, a la resolución, las precisiones que el artículo 79.2 de la LPA situaba y el artículo 58.2 LRJPAC [hoy art. 40.2 LPACAP] sigue situando, más, concretamente, como contenido necesario de las notificaciones. Es un error técnico notorio, como la jurisprudencia constitucional ha subrayado a propósito de los defectos de notificación de las sentencias y demás resoluciones judiciales, confundir éstas con su preceptiva notificación, que es algo distinto a la resolución, que se añade a ésta, pero que, obviamente, no forma parte de la misma, aunque, eso sí, condicione su eficacia». GARCÍA DE ENTERRÍA, E.: Curso..., op. cit., vol. II, pág. 505.

${ }^{83}$ Este caso no se enmarca como supuesto de acta con disconformidad en el art. 188.1 RGGI.

${ }^{84}$ Prosigue el art. 185.2.2. ${ }^{\circ}$ RGGI [en la redacción vigente hasta el 30.06.2018] «...De cada acta se entregará un ejemplar al obligado tributario, que se entenderá notificada por su firma. Si aquel no hubiera comparecido, las actas deberán ser notificadas conforme lo dispuesto en la Ley 58/2003, de 17 de diciembre, General Tributaria, y se considerará como dilación no imputable a la Administración el tiempo transcurrido desde la fecha fijada para la firma de las actas hasta la fecha de notificación de las mismas. Si el obligado tributario compareciese y se negase a suscribir las actas se considerará rechazada la notificación a efectos de lo previsto en el artículo 111 de dicha ley. Cuando el interesado no comparezca o se niegue a suscribir las actas, deberán formalizarse actas de disconformidad.». Hemos de tener en cuenta que la redacción del art. 185.2.2. ${ }^{\circ}$ RGGI a partir del 1.7.2018 será la siguiente «... Si el obligado tributario no hubiera comparecido, las actas deberán ser notificadas conforme lo dispuesto en la Ley 58/2003, de 17 de diciembre, General Tributaria, y se suspenderá el cómputo del plazo del procedimiento inspector desde el intento de notificación del acta al obligado tributario hasta que se consiga efectuar la notificación. Si el obligado tributario compareciese y se negase a suscribir las actas se considerará rechazada la notificación a efectos de lo previsto en el artículo 111 de dicha ley. Cuando el interesado no comparezca o se niegue a suscribir las actas, deberán formalizarse actas de disconformidad ".

${ }^{85}$ De igual modo el plazo de resolución se cuenta desde la fecha de notificación al interesado del acuerdo de inicio. GARCÍA BERRO, F.: Los procedimientos tributarios y la Ley 30/1992 desde la nueva perspectiva de la Ley 1/1998, de derechos y garantías de los contribuyentes, Marcial Pons, Madrid-Barcelona, 1998, pág. 106.

${ }^{86}$ Con independencia del tipo de procedimiento tributario o sancionador tributario en que nos encontremos, el modo de efectuar las notificaciones será idéntico. 
lo dispuesto en los artículos $109^{87}$ a 112 LGT $^{88}$ y 114 a 115 ter RD $1065 / 2007^{89}$, y, en lo que no resulte contradictorio con las especialidades de dichos preceptos, por lo previsto en los arts. 39 a 46 y DA $1 .{ }^{\mathrm{a}} \cdot 2 .^{\circ}$ LPACAP y a los arts. $14,16,17,22.4 .^{\circ}, 23,24$ Ley 43/2010, de 30 de diciembre, del servicio postal universal, de los derechos de los usuarios y del mercado postal y a los arts. 39 a 44 del RD 1829/1999, de 3 de diciembre, de 3 de diciembre, por el que se aprueba el Reglamento por el que se regula la prestación de los servicios postales, en desarrollo de lo establecido en la Ley 24/1998, de 13 de julio, del Servicio Postal Universal y de Liberalización de los Servicios Postales ${ }^{90}$, con la regulación especial de las actas con conformidad contempladas en el artículo 211.1. ‥1 LGT.

Considerada la notificación como acto de trámite, y visto que el mismo contiene, en estos instantes del proceso, un acto interruptivo de la prescripción de la acción para sancionar, el mismo será irrecurrible, salvo que vulnere alguna garantía fundamental del obligado (como el derecho a la recusación del órgano competente o por no in-

87 Entendemos que la remisión del artículo 109 a los artículos 39 a 46 y DA $1 .^{\mathrm{a}} \cdot 2 .^{\circ}$ LPACAP prevalece sobre los preceptos 114 a 115 ter RGGI, no sólo por que la LGT no remite directamente a su reglamento que la desarrolle con carácter preferente, sino porque su propio artículo 1 RGGI así lo restringe. En este orden de cosas, y en tanto en cuanto no contradigan lo dispuesto en la LGT y LPACAP, habrá que estarse a lo dispuesto en los arts. 14, 16, 17, 22.4. ${ }^{\circ}, 23,24$ Ley 43/2010, de 30 de diciembre, del servicio postal universal, de los derechos de los usuarios y del mercado postal y a los arts. 39 a 44 del RD 1829/1999, de 3 de diciembre, de 3 de diciembre, por el que se aprueba el Reglamento por el que se regula la prestación de los servicios postales, en desarrollo de lo establecido en la Ley 24/1998, de 13 de julio, del Servicio Postal Universal y de Liberalización de los Servicios Postales.

${ }^{88}$ En relación a las notificaciones defectuosas la nueva LGT ha eliminado por fin las especialidades existentes hasta ahora para el ámbito tributario. Dichas especialidades, por cierto, se habían producido de forma sobrevenida, debido a que la modificación del régimen general en este punto por obra de la LRJPAC no fue seguida de la consiguiente adaptación de la normativa tributaria...por tanto surte todos sus efectos la remisión del artículo 109 al régimen administrativo general. Si se mantienen no obstante las normas específicas relativas al contenido y forma de de practicarla. GARCÍA BERRO, F.: Los procedimientos..., op. cit., págs. 143 y 148 a 153.

${ }^{89}$ Hemos de resaltar la remisión al régimen de la práctica de la notificación administrativa común establecido en el nuevo art. 115 bis RGGI, en su redacción dada por el RD 1070/2017, sin perjuicio de la deslegalización absoluta de las especialidades de la notificación «de actuaciones estatales» en favor de una Orden ministerial.

${ }_{90}$ Como indicamos con anterioridad (en nota 79), téngase en cuenta que quedan derogados cuantos preceptos de esta norma contradigan lo dispuesto en el Real Decreto 1298/2006, de 10 de noviembre, según establece su disposición derogatoria única. 
dicar quien es el órgano instructor), en cuyo caso, opinamos ${ }^{91}$ debería admitirse la posibilidad de su reclamación independiente.

La fecha de notificación del acuerdo, además de marcar el inicio del cómputo de los tres meses, interrumpe el plazo para sancionar, como determina el artículo 189.3.a) de la LGT, siendo irrecurrible al tratarse de un acto de mero trámite que no determina, en principio, la imposibilidad de continuar el procedimiento o causa indefensión (art. 112.1 LPACAP) ${ }^{92}$.

La emisión formal del acuerdo de iniciación del procedimiento, sin embargo, no origina per se, y sin más, el efectivo inicio del expediente, en el sentido de generar el clásico efecto de la litispendencia, por cuanto el ordenamiento anuda ese efecto, no al simple acto de redacción o cumplimentación del citado acuerdo, sino, en concreto, al acto de su notificación al presunto responsable (arts. 209.1 LGT, 22.1 RGRST). Puede decirse, en consecuencia, que el procedimiento sancionador tributario no nace al mundo del Derecho sino hasta el preciso instante en que el mismo sea debidamente notificado a dicho interesado.

Una primera especialidad radica en la necesidad de que el acuerdo por el que se decreta la apertura del expediente sea notificado, no solo al interesado en virtud de lo expresado en los arts. 209.1 LGT y 22.1 RGRST, entendiendo en todo caso por tal al inculpado, sino también [comunicado] a la persona designada para dirigir y desarrollar la fase de instrucción del procedimiento (el instructor, ex art. 23.1 RGRST), el cual, por el juego de las normas reguladoras de la competencia, no será el mismo que haya procedido a acordar la iniciación del expediente.

Ahora bien, debemos plantearnos a qué personas debe notificarse para que se entienda notificado el acuerdo y no caduque la posibilidad de incoación del procedimiento sancionador, estimando que lo será al interesado afectado, presunto responsable, o a su representante, puesto que ellos son el objeto de la notificación a que refiere el artículo 208.3. ${ }^{\circ}$ de la LGT. Al órgano instructor sólo se le comunicará el acuerdo de iniciación y se le dará traslado de las actuaciones, por mor del artículo 64.1. ${ }^{\circ}$ LPACAP. Como argumentación de lo sostenido, hemos de estar al tenor del párrafo segundo del artículo 211 de la LGT cuando expresa que «el procedimiento sancionador en materia tributaria deberá concluir en el plazo máximo de seis meses con-

91 ANÍBARRO PÉREZ, S. y SESMA SÁNCHEZ, B.: Infracciones..., op. cit., pág. 230.

92 CALDERÓN GONZÁLEZ, J.M.: «El procedimiento sancionador...», op. cit. 
tados desde la notificación de la comunicación de inicio del procedimiento.»

Sobre este último inciso, en primer lugar, entendemos las «comunicaciones» como los documentos a través de los cuales la Administración notifica al obligado tributario el inicio del procedimiento $\mathrm{u}$ otros hechos o circunstancias relativos al mismo o efectúa los requerimientos que sean necesarios a cualquier persona o entidad (art. 99.7. .2 LGT). Dicho artículo 99 se encuentra en la subsección primera, de la sección primera del capítulo segundo del Título III de la LGT, aplicable, ex artículo 97 LGT, a las actuaciones y procedimientos de aplicación de los tributos y no al procedimiento sancionador tributario regulado en el Título IV. Por ello, hubiera resultado más apropiado utilizar la terminología propia del procedimiento administrativo común, por remisión del artículo 207.b) de la LGT, que refinadamente ha utilizado el artículo 22.1. ${ }^{\circ}$ del RGRST, todo ello por no existir una definición propia de comunicación aplicable al procedimiento sancionador tributario.

En la notificación, reiteramos, debemos considerar como requisito sine qua non su práctica dentro del plazo de los tres meses, que prevé el artículo 209.2. ${ }^{\circ}$ LGT, para que no caduque la posibilidad de incoar el procedimiento sancionador, no bastando con que se dicte el acuerdo de iniciación del procedimiento sancionador dentro de dicho plazo de tres meses. Esta conclusión puede extraerse del juego de los artículos 22.1. ${ }^{\circ}$ RGRST que preceptúa que «el procedimiento se iniciará... mediante la notificación del acuerdo..» y el artículo 209.2. ${ }^{\circ}$ LGT cuando norma «...no podrán iniciarse respecto a la persona o entidad que hubiera sido objeto del procedimiento una vez transcurrido el plazo de tres meses ${ }^{93}$ desde que se hubiese notificado o se entendiese notificada la correspondiente liquidación o resolución». Por ello, transcurridos tres meses sin que se haya notificado el acuerdo de incoación, debemos entender que la posibilidad de adoptar acuerdo incoatorio ha caducado, aunque no haya prescrito la responsabilidad por la supuesta infracción. Así un acuerdo de iniciación acordado dentro del plazo y remitida la notificación o comunicación vía operador del servicio postal, si se notifica de modo efectivo fuera del plazo de los tres meses, deberemos entender que el acuerdo se notifica caducada ya la posibilidad de su incoación, con lo que deberá procederse a la resolución de archivo. De igual modo, si existe al menos un intento de notificación dentro de dicho plazo de

93 Estamos ante un plazo de caducidad. MARTÍN QUERALT, J; LOZANO SERRANO, C.; POVEDA BLANCO, F.: Derecho Tributario, Aranzadi, Navarra, 2008, pág. 229. 
tres meses, deberemos entender por no efectuada dicha notificación ${ }^{94}$, al no prever la LGT dicha previsión para el cómputo del plazo de incoación ${ }^{95}$.

En segundo lugar, quede claro que el plazo para la terminación del procedimiento sancionador tributario se hace depender del momento en que se notifique el acuerdo de incoación del procedimiento sancionador.

En tercer lugar, conforme expone el artículo 209.1. ${ }^{\circ}$ LGT, el procedimiento se iniciará mediante la notificación del acuerdo del órgano competente, y no con la simple resolución.

\section{III.4. Órgano incoador del procedimiento sancionador tributario}

En principio, habrá que entender, con carácter general, que los órganos encargados de la iniciación del procedimiento sancionador - ya sean competentes los de gestión, recaudación o los de inspección-, cuando tengan constancia de que se ha cometido una infrac-

94 Excepción hecha de los supuestos del artículo 43 del RD 1829/1999, que contempla los supuestos en los que «no procederá un segundo intento de entrega».

${ }_{95}$ Por el contrario el artículo 211.2 LGT sí prevé que «el procedimiento sancionador en materia tributaria deberá concluir en el plazo máximo de seis meses contados desde la notificación de la comunicación de inicio del procedimiento. Se entenderá que el procedimiento concluye en la fecha en que se notifique el acto administrativo de resolución del mismo. A efectos de entender cumplida la obligación de notificar y de computar el plazo de resolución serán aplicables las reglas contenidas en el apartado 2 del artículo 104 de esta ley». Este artículo apunta «A los solos efectos de entender cumplida la obligación de notificar dentro del plazo máximo de duración de los procedimientos, será suficiente acreditar que se ha realizado un intento de notificación que contenga el texto íntegro de la resolución. En el caso de sujetos obligados o acogidos voluntariamente a recibir notificaciones practicadas a través de medios electrónicos, la obligación de notificar dentro del plazo máximo de duración de los procedimientos se entenderá cumplida con la puesta a disposición de la notificación en la sede electrónica de la Administración Tributaria o en la dirección electrónica habilitada» (art. 104.2.LGT). Por tanto, si el modo de notificar previsto en el art. 104.2.2. ${ }^{\circ}$ LGT lo es únicamente a los efectos de entender cumplido el "primer" intento de notificación dentro del plazo máximo establecido para el procedimiento tributario correspondiente, no podemos entender que la notificación se entienda correctamente practicada hasta que se hayan cumplido las formalidades a las que se refiere el art. 109 LGT cuando indica que «[e]l régimen de notificaciones será el previsto en las normas administrativas generales con las especialidades establecidas en esta sección (lugar de notificación, personas legitimadas para recepcionar notificaciones y la notificación edictal).» En un sentido un tanto matizado, vid. art. 115.2 RGGI en la redacción que le otorga - a partir del 1.07.2018 - el RD 1065/2017, pues un reglamento deslegaliza e infraordena - a través de una remisión en blanco a una Orden Ministerial- el régimen de notificaciones electrónica, incluso de modo contrario a lo dispuesto en la LGT. 
ción, deberán iniciar el procedimiento, ex officium, y así, para algunos autores ${ }^{96}$, inicialmente nada impide el procedimiento sancionador se incoe y se desarrolle paralelamente al de declaración, verificación de datos, comprobación o inspección.

En su desarrollo, el Real Decreto 2063/2004, de 15 de octubre, en su artículo 22.3. .b) manifiesta que «en los procedimientos sancionadores iniciados por órganos de inspección será competente para iniciar el procedimiento sancionador el equipo o unidad que haya desarrollado las actuaciones - distintas de las que integran el procedimiento inspector- de las que trae su causa la infracción». Este apartado es poco claro en cuanto si ese desarrollo exige o no de resolución definitiva en la vía administrativa, o basta que se hayan llevado a término unas actuaciones en el procedimiento aunque no se haya terminado definitivamente el mismo $^{97}$. Sin embargo, el apar-

96 El plazo de tres meses del art. 209.2 LGT opera como límite temporal máximo para la iniciación del expediente sancionador respecto de un previo procedimiento de inspección o de alguno de los procedimientos de aplicación de los tributos citados en el mismo, pero tampoco es necesario que haya concluido con carácter previo un procedimiento de comprobación o de aplicación de los tributos para que pueda iniciarse un expediente sancionador. Es decir, si la imposición de sanciones junto con la deuda puede simultanearse en el caso de las actas con acuerdo y en los casos de renuncia a la tramitación separada del procedimiento, entonces es que podrían tramitarse simultáneamente, aunque de forma separada, alguno de aquellos procedimientos y el propio procedimiento sancionador. Es cierto que en la mayoría de los casos para fijar la sanción será necesario conocer con carácter previo la cuota defraudada, pero tal requisito no es siempre necesario y la regulación actual del procedimiento sancionador permite varias posibilidades para conocer este dato antes de resolver el expediente sancionador, v.gr. demorando la notificación del inicio del procedimiento sancionador aunque el obligado hubiera renunciado a la tramitación separada del procedimiento. ANÍBARRO PÉREZ y SESMA SÁNCHEZ en la obra colectiva del Profesor CALVO ORTEGA, R.: ..., op. cit., pág. 329; De dicho parecer es la RTEAC de 9 de octubre de 2002; También la SAN de 22 de julio de 2009 $\left(\right.$ FJ $\left.3 .^{\circ}\right)$ «La interpretación de tales preceptos se presenta clara, el mandato legal establece la prohibición de iniciar procedimiento sancionador en los supuestos que establece, en el que se incluye el de autos, transcurrido el plazo de tres meses desde la notificación de la liquidación o resolución, mas en modo alguno se contempla que esté vedado autorizarlo antes de esa notificación, ni en su sentido literal, ni aplicando los restantes elementos interpretativos, y dentro de esa cobertura legal el precepto reglamentario contempla el requisito necesario para iniciarlo, la autorización que puede ser conferida en cualquier momento del procedimiento de comprobación e investigación. El hecho apuntado por la actora de que hasta que no existe liquidación la propia cuota sigue en entredicho, es decir, no existe deuda tributaria que haya podido ser en su caso, objeto de defraudación, lo que obliga esperar a la concurrencia de un acto administrativo liquidatorio que sirva de basa a la sanción para poder iniciar un expediente sancionador, con no ser una consecuencia que se da en todo caso, en nada empece a la aplicación de unos textos legales y reglamentarios inobjetables.»

${ }^{97} \mathrm{La}$ interpretación de tales preceptos se presenta clara, el mandato legal establece la prohibición de iniciar procedimiento sancionador en los supuestos que es- 
tado $4 .^{\circ}$ de dicho artículo 22 RGRST es conciso cuando matiza «se iniciarán tantos procedimientos sancionadores como propuestas de liquidación se hayan dictado, sin perjuicio de los que hayan de iniciarse por las conductas constitutivas de infracción puestas de manifiesto durante el procedimiento y que no impliquen liquidación...», por ello queda patente que el acto no necesariamente ha de ser el resolutivo, aunque las actuaciones que deben existir y que se mentan en el artículo deben entenderse referidas a una o varias propuestas de liquidación, por lo que en caso de que comporten liquidación económica no podrá incoarse expediente sancionador con anterioridad a dicho trámite. En caso de conductas infractoras que no comporten liquidación ${ }^{98}$, se podrá incoar el procedimiento sancionador en cualquier momento ${ }^{99}$, bastando que queden puestas de manifiesto dichas conductas en el expediente de aplicación de los tributos.

En parecido sentido, los artículos 22.3. ${ }^{\circ}$ a) y $25.1 .^{\circ}$ RGRST, exponen que «si el procedimiento sancionador se inicia como consecuencia de un procedimiento de inspección será competente para acordar la iniciación del procedimiento sancionador el equipo o unidad que hubiera desarrollado la actuación de comprobación e investigación...». Sin embargo, "cuando el inicio y la tramitación correspondan al mismo equipo o unidad que haya desarrollado o esté desarrollando ${ }^{100}$ las actuaciones de comprobación e investigación, el

tablece, en el que se incluye el de autos, transcurrido el plazo de tres meses desde la notificación de la liquidación o resolución, mas en modo alguno se contempla que esté vedado autorizarlo antes de esa notificación, ni en su sentido literal, ni aplicando los restantes elementos interpretativos, y dentro de esa cobertura legal el precepto reglamentario contempla el requisito necesario para iniciarlo, la autorización que puede ser conferida en cualquier momento del procedimiento de comprobación e investigación. El hecho apuntado por la actora de que hasta que no existe liquidación la propia cuota sigue en entredicho, es decir, no existe deuda tributaria que haya podido ser en su caso, objeto de defraudación, lo que obliga esperar a la concurrencia de un acto administrativo liquidatorio que sirva de basa a la sanción para poder iniciar un expediente sancionador, con no ser una consecuencia que se da en todo caso, en nada empece a la aplicación de unos textos legales y reglamentarios inobjetables (SAN, Sección 4. ${ }^{\text {a }}$, Sentencia de 22 Jul. 2009, rec. 241/2008).

${ }_{98}$ Así en el caso de incumplimientos de deberes formales.

99 Dicho apartado resulta un tanto contradictorio con el tenor del artículo 192.2. ${ }^{\circ}$ del RD 1065/2007, de 15 de julio, cuando señala que «finalizado el trámite de audiencia, se procederá a documentar el resultado de las actuaciones de comprobación e investigación en diligencia o informe. Cuando el procedimiento finalice mediante diligencia o informe, esta se incorporará al expediente sancionador que, en su caso, se inicie como consecuencia del procedimiento de inspección, sin perjuicio de la remisión que deba efectuarse cuando resulte necesario para la iniciación de otro procedimiento de aplicación de los tributos».

100 Este apartado gramaticalmente extiende lo que indica el precedente, así si el anterior establecía que el competente era el hubiera desarrollado - esto es, ya ha acabado- la actuación, ahora amplía dicha competencia con el que haya desarro- 
acuerdo de inicio podrá suscribirse por el jefe del equipo o unidad o por el funcionario que haya suscrito o vaya a suscribir las actas ${ }^{101}$. En otro caso, la firma corresponderá al jefe de equipo o unidad o al funcionario que determine el inspector-jefe. En todo caso, el inicio del procedimiento sancionador requerirá autorización ${ }^{102}$ previa del inspector-jefe ${ }^{103}$, que podrá ser concedida en cualquier momento del procedimiento de comprobación e investigación o una vez finalizado este,...». Por último, incrementa la labor de interpretación el artículo 25.2. ${ }^{\circ}$ RGRST, cuando regula que «se iniciarán tantos procedimientos sancionadores como actas de inspección se hayan incoado ${ }^{104}$,

llado - ya finalizado las actuaciones- o esté desarrollando - dichas actuaciones, que aún no han acabado-. Igualmente, el párrafo primero del art. 25.1. ${ }^{\circ}$ RGRST, indica la competencia para «acordar la iniciación», sin embargo, el párrafo segundo de dicho precepto establece la atribución para la suscripción del acuerdo.

101 Cuando el precepto apunta o vaya a suscribir las actas debemos comprender que refiere a que dicho jefe sea el competente para suscribir las actas, y no que necesariamente deba suscribirlas, puesto que siempre podrá rectificarlas.

${ }_{102}$ Tal autorización puede prestarla el Inspector Jefe tanto con anterioridad a la incoación del acta - el reglamento habla de cualquier momento en cualquier momento del procedimiento de comprobación e investigación- o puede efectuarse dentro del plazo de tres meses a que se ha hecho alusión. Ahora bien, para que la autorización tenga validez debe ser concreta y específica, con referencia al procedimiento en que se dicta y con justificación, aun sucinta, de las razones por las que el procedimiento sancionador es procedente, de donde resulta un tanto precipitado adoptarla antes de conocerse el acta, pues es este acto el que contiene una propuesta de regularización en la que se podrá poner de manifiesto, en su caso, la procedencia de abrir el expediente sancionador. De no ser así, lo que sucede con frecuencia con autorizaciones genéricas o pro futuro, no cabrá entender interrumpido el plazo de caducidad, que es sin duda el propósito que abriga la fórmula reglamentaria (12) para soslayar la exigencia de ese plazo. NAVARRO SANCHÍS, F.J; URBANO CASTRILLO, E.: «El procedimiento sancionador», en la obra colectiva $L a$ deuda fiscal. Cuestiones candentes de Derecho Administrativo y Penal, La Ley, edición núm. 1, Madrid, octubre de 2009.

${ }_{103}$ Así el artículo indica que se requiere de autorización previa para la incoación del procedimiento sancionador, y que dicha autorización se «puede» obtener en el ínterin o una vez finalizado el procedimiento de comprobación o investigación, silenciando si cabe obtener dicha autorización simultáneamente al inicio de ambos, aunque basta una lectura de los dos artículos analizados para adverar que no cabe antes de que se empiecen a desarrollar las actuaciones; No creemos que dicha autorización se haya configurado como un requisito procedimental imprescindible. Su finalidad responde, más que nada, a la necesidad de controlar los expedientes sancionadores que puedan incoarse y a sus circunstancias. ANÍBARRO PÉREZ y SESMA SÁNCHEZ en la obra colectiva del Profesor CALVO ORTEGA, R.: ..., op. cit., pág. 354 .

${ }_{104}$ El plazo de tres meses del art. 209.2 LGT opera como límite temporal máximo para la iniciación del expediente sancionador respecto de un previo procedimiento de inspección o de alguno de los procedimientos de aplicación de los tributos citados en el mismo, pero tampoco es necesario que haya concluido con carácter previo un procedimiento de comprobación o de aplicación de los tributos para que pueda iniciarse un expediente sancionador. Es decir, si la imposición 
sin perjuicio de los que hayan de iniciarse por las conductas constitutivas de infracción puestas de manifiesto durante el procedimiento inspector y que no impliquen liquidación...», de donde puede desprenderse que «hasta que no se incoa el acta no puede iniciarse el procedimiento sancionador». Además de esta referencia, existen otros indicios en la normativa vigente que hacen pensar que, en estos casos, el procedimiento sancionador debe comenzar una vez que el expediente, derivado de las actuaciones de comprobación e investigación, ha sido instruido. Entre estos indicios se encuentra el hecho de que el artículo 210.2. ${ }^{\circ}$ de la LGT disponga que «los datos, pruebas o circunstancias que obren o hayan sido obtenidos en alguno de los procedimientos de aplicación de los tributos regulados en el título III de esta ley y vayan a ser tenidos en cuenta en el procedimiento sancionador deberán incorporarse ${ }^{105}$ formalmente al mismo antes de la propuesta de resolución».

de sanciones junto con la deuda puede simultanearse en el caso de las actas con acuerdo y en los casos de renuncia a la tramitación separada del procedimiento, entonces es que podrían tramitarse simultáneamente, aunque de forma separada, alguno de aquellos procedimientos y el propio procedimiento sancionador. Es cierto que en la mayoría de los casos para fijar la sanción será necesario conocer con carácter previo la cuota defraudada, pero tal requisito no es siempre necesario y la regulación actual del procedimiento sancionador permite varias posibilidades para conocer este dato antes de resolver el expediente sancionador, v.gr. demorando la notificación del inicio del procedimiento sancionador aunque el obligado hubiera renunciado a la tramitación separada del procedimiento. ANÍBARRO PÉREZ y SESMA SÁNCHEZ en la obra colectiva del Profesor CALVO ORTEGA, R.: ..., op. cit., pág. 329; De dicho parecer es la RTEAC de 9 de octubre de 2002.

${ }^{105}$ La incorporación formal, y, sin restricción alguna, al expediente sancionador de los datos y pruebas autoincriminatorias obtenidas de forma coactiva durante un procedimiento de aplicación de los tributos plantea un problema entre el deber de colaborar y el derecho a no autoincriminarse, no confesarse culpable o el derecho a guardar silencio. En todo caso debe rechazarse que junto a la incorporación formal se aporten juicios de valor sobre el contenido de los datos, de imputabilidad de grado alguno de culpa y de las consecuencias que se pudieran derivar en el curso del procedimiento sancionador, puesto que es en éste donde se debe imputar el grado de responsabilidad y de culpabilidad, esto es, los reproches se deben ejercitar en el PS. El deber de colaborar trae causa del deber constitucional de contribuir $\mathrm{y}$, en consecuencia, no pueden ser invocados principios y garantías que han de operar en el orden punitivo (... principio de no autoinculpación) por cuanto, no se está imputando ningún ilícito al obligado tributario. Ahora bien, teniendo en cuenta que el artículo 6 (derecho a un juicio justo) del Convenio para la Protección de los Derechos Humanos y las Libertades Fundamentales, de 4 de noviembre 1950, es aplicable, según doctrina del TEDH, a la potestad sancionadora de la Administración pudiera establecerse que no se pueden utilizar pruebas aportadas por el sujeto pasivo que legítimamente podría invocar en el curso de un PS el derecho a no autoinculparse (respetuosa con el TEDH en Sentencia de 17 de diciembre de 1996, Sanders contra Reino Unido o la de 3 de mayo de 2001, J. B. contra Suiza). Ahora bien, la Sentencia de la AN de 6 de abril de 2004 (Rec. 55/2002), entiende que la incorporación al expediente sancionador de pruebas y documentos del previo expediente 
De lo expuesto se puede concluir que el procedimiento sancionador tributario, en el caso que dimane del procedimiento inspector, y a pesar de la separación de procedimientos, «aquél se reduce a un mero apéndice de éste procedimiento» ${ }^{106}$, puesto que es evidente que está vinculado al acta ${ }^{107}$ de la que trae causa. Todo esto nos lleva a afirmar ${ }^{108}$ que en lugar de un procedimiento sancionador tributario único, se ha establecido uno general y otro especial para las actuaciones de la inspección de los tributos.

En este sentido, esta articulación entre el procedimiento de liquidación y el sancionador parece quedar reflejada en la redacción del artículo 153 de la LGT, concretamente en sus epígrafes f) y g), en donde se establece que en las actas de la inspección que documen-

de comprobación no supone una violación del derecho fundamental a no declarar contra sí mismo, puesto que durante la tramitación de este último siempre será posible guardar silencio «... porque si bien es cierto que, con arreglo a la jurisprudencia invocada del TEDH, el derecho a no declarar contra sí mismo tiene eficacia en el marco de un procedimiento sancionador, sea penal o administrativo, el mismo debe tener virtualidad desde que existen indicios fundados de que una conducta va a determinar la apertura de un expediente sancionador; por ello no puede servir para impedir que con carácter previo a la iniciación de un procedimiento sancionador, puedan y deban practicarse medidas de inspección y comprobación (...) pudiendo traer a colación la significativa jurisprudencia del propio Tribunal de Estrasburgo (por todos, acerca de la configuración de las garantías procesales, particularmente del derecho a guardar silencio, la Sentencia del 8 de febrero de 1996. Caso John Murray contra Reino Unido). (...) hubiera podido oponer como derecho, el guardar silencio, que debe entenderse, en cualquier caso, independiente del deber de contribuir al sostenimiento de las cargas públicas con arreglo a los principios establecidos en el artículo 31.1 CE y para cuya efectividad el ordenamiento Jurídico instrumenta determinados deberes de colaboración que recaen sobre el propio contribuyente y cuya infracción puede hacerle incurrir incluso en responsabilidad administrativa [el artículo 82.1.b)] de la Ley General Tributaria permite graduar las sanciones (...) en los casos de resistencia, negativa u obstrucción de la acción investigadora». MORATO MIGUEL, L.C.: "El régimen sancionador tributario», en la obra colectiva $E l$ Sistema Fiscal Español y las Entidades y Operaciones Financieras, La Ley, edición núm. 1, Madrid, abril de 2006.

106 RICARDO HOYOS, J.: «El procedimiento ...», op. cit., pág. 12.

$107 \mathrm{El}$ art. 143.2. ${ }^{\circ}$ LGT define las actas como «los documentos públicos que extiende la inspección de los tributos con el fin de recoger el resultado de las actuaciones inspectoras de comprobación e investigación, proponiendo la regularización que estime procedente de la situación tributaria del obligado o declarando correcta la misma», por tanto casa mal que el RGRST considere la incoación de actas de inspección, resultando más propio que hubiere normado que se iniciarán tantos procedimientos sancionadores como actas de inspección se hayan propuesto.

${ }^{108}$ Las afirmaciones las realizó constante la Ley 1/1998, por podrían resultar igualmente aplicables hoy día para el caso del procedimiento sancionador con tramitación separada, considerando la existencia de dos subtipos de procedimientos. RUIZ DE PALACIOS VILLAVERDE, J.I., en la obra colectiva, coordinada por ORÓN MORATAL, Estatuto del Contribuyente,. Ley 1/1998, de. Derechos y Garantías de los Contribuyentes, Ed. Francis Lefevbre, Madrid, 1998. 
ten el resultado de su actuación se hará constar, entre otros, «la expresión de los trámites del procedimiento posteriores al acta »y, en su caso, «la existencia o inexistencia, en opinión del actuario, de indicios de la comisión de infracciones tributarias.» Mayor vinculación, si cabe, se describe en el artículo 155.2, letra c) LGT cuando previene que, «además de lo dispuesto en el artículo 153 de esta ley, el acta con acuerdo incluirá necesariamente el siguiente contenido: c) Los elementos de hecho, fundamentos jurídicos y cuantificación de la propuesta de sanción que en su caso proceda, a la que será de aplicación la reducción prevista en el apartado 1 del artículo 188 de esta ley, así como la renuncia a la tramitación separada del procedimiento sancionador ».

Insistiendo en lo expuesto en líneas precedentes, de los preceptos señalados se deduce, tal y como afirmamos ${ }^{109}$ "que existe una sucesión temporal entre el término de las actuaciones de comprobación e investigación, la extensión de la correspondiente acta, y el inicio del correspondiente expediente para sancionar las infracciones ...». Por ello, si tan sólo se iniciara el procedimiento sancionador sin continuar las actuaciones subsiguientes, a la espera de que se incoara el acta, la mera iniciación del procedimiento sancionador podría llegar a considerarse una simple operación dilatoria del plazo prescripción $^{110}$.

En realidad, se puede decir ${ }^{111}$ que tal y como se configura, en la actualidad, la tramitación separada de los procedimientos sancionador y de inspección, ello nos conduce a defender, por prudencia, la sucesión temporal del de liquidación y el sancionador, ya que si en las actuaciones de comprobación e investigación se manifiestan posibles infracciones tributarias, como las de dejar de ingresar, que no pueden constatarse hasta que la cuota se haya cuantificado, resulta más factible ${ }^{112}$ que el procedimiento sancionador se inicie fi-

109 CERVERA TORREJÓN, F., MAGRANER MORENO, F. y JUAN LOZANO, A.M.: «Análisis crítico...», op. cit., pág. 18.

110 Sin embargo, hemos de expresar que en la actualidad, basta una lectura de los artículos 68 LGT, y 103. ${ }^{a} 104$ RGGI, para entender que la mera iniciación del procedimiento sancionador no interrumpe la prescripción de los posteriores procedimientos de aplicación de los tributos, sin perjuicio de que, ex art. 189.3.a) LGT las acciones conducentes a la regularización sí interrumpan la prescripción del procedimiento sancionador.

111 BLASCO DELGADO, C.; La prescripción..., op. cit., pág. 106.

112 También hay que tener en cuenta que conforme al art. 190.1. ${ }^{\circ}$ del RD 1065/2007, de 27 de julio, "1. Las liquidaciones derivadas de un procedimiento de inspección tendrán carácter definitivo o provisional de acuerdo con lo dispuesto en el artículo 101 de la Ley 58/2003, de 17 de diciembre, General Tributaria, y en este artículo. Las liquidaciones derivadas de las actuaciones de 
nalizada la tramitación de las actuaciones de comprobación e investigación $^{113}$. Estas mismas conclusiones debemos aplicarlas en los supuestos de procedimientos de gestión y recaudación, ya que con meras propuestas de resolución se llegan a incoar procedimientos sancionadores que, en un momento dado, podrían quedar en papel mojado si se rectificase la propuesta de acuerdo, o bien fuese recurrida y se estimase la pretensión del demandante en reposición, en vía económico-administrativa o contencioso-administrativa.

No obstante, y a pesar de que nos parece más acorde al principio de seguridad jurídica la interpretación que acaba de exponerse, tampoco se encuentra en las normas vigentes ninguna prohibición expresa que impida que el procedimiento sancionador se desarrolle, siempre que ello sea posible, de forma paralela al de gestión, recaudación o investigación. Así el procedimiento del artículo 25 RGRST puede iniciarse durante la tramitación o tras la finalización del procedimiento inspector, sin perjuicio de los plazos en que deba ejercitarse tras su finalización. De este modo podemos concluir ${ }^{114}$ que el procedimiento sancionador puede iniciarse con carácter previo a la finalización de los procedimientos de aplicación de los tributos de los que pueda traer causa.

comprobación e investigación de alcance parcial tendrán siempre el carácter de provisionales», en consecuencia, «6. ${ }^{\circ}$ Los elementos de la obligación tributaria comprobados e investigados en el curso de unas actuaciones que hubieran terminado con una liquidación provisional no podrán regularizarse nuevamente en un procedimiento inspector posterior, salvo que concurra alguna de las circunstancias a que se refieren los apartados 2 y 3 de este artículo 190 y, exclusivamente, en relación con los elementos de la obligación tributaria afectados por dichas circunstancias. Cuando concurran las circunstancias del artículo 190.3.b) de este reglamento, la regularización se podrá realizar con los nuevos datos que se hayan podido obtener y los que se deriven de la investigación de los mismos. [Este segundo inciso del apartado $6 .^{\circ}$ estará vigente a partir del 1.7.2018]. 7. ${ }^{\circ}$ Los elementos de la obligación tributaria a los que no se hayan extendido las actuaciones de comprobación e investigación podrán regularizarse en un procedimiento de comprobación o investigación posterior».

113 RUIZ TOLEDANO, J.I.: «El procedimiento...», op. cit.

114 BLASCO DELGADO, C.: La prescripción..., op. cit., pág. 108; también ANEIROS PEREIRA, J.: Las sanciones..., op. cit., págs. 202 y 203; RICARDO HOYOS, J.: «El procedimiento...», op. cit., pág. 12; STSJ Castilla y León de 15 de noviembre de 2002; en contra, debe iniciarse después de que se practiquen las liquidaciones correspondientes, MUÑÓZ BAÑOS, C.: «Algunas reflexiones acerca del procedimiento sancionador tributario», RDFHP, núm. 258, 2000, pág. 951; FENELLÓS PUIGCERVER, V.: El Estatuto del Contribuyente. Comentarios a la Ley 1/1998, de 26 de febrero, de derechos y garantías de los contribuyentes, Tro, Valencia, 1998, pág. 370; GARCÍA IZQUIERDO, S.: Comentarios..., op. cit., pág. 12; SsTSJ de Galicia de 30 de septiembre de 2002, de Castilla y León de 13 de diciembre de 2002 y Murcia de 7 de mayo de 1998. 


\section{III.5. Tipos de formas de terminación de los procedimientos de aplicación de los tributos de los que trae causa la caducidad en la iniciación del procedimiento sancionador tributario}

Dos son las modalidades de terminación que deben de ser notificadas a los efectos del artículo 209.2. ${ }^{\circ}$ LGT, la resolución y la liquidación.

Respecto a la primera modalidad, el contenido necesario resolutivo se puede encontrar en el artículo 88.3. ${ }^{\circ}$ LPACAP, y así «las resoluciones contendrán la decisión, que será motivada en los casos a que se refiere el artículo 35. Expresarán, además, los recursos que contra la misma procedan, órgano administrativo o judicial ante el que hubieran de presentarse y plazo para interponerlos, sin perjuicio de que los interesados puedan ejercitar cualquier otro que estimen oportuno».

\section{III.6. Intervención en el procedimiento sancionador tributario del responsable tributario en el pago de la sanción tributaria}

Vislumbramos ${ }^{115}$ la tramitación que deba seguirse ante la existencia de la infracción tributaria cometida por un responsable tributario - cuando se detecte en el curso de un procedimiento de inspección-, habida cuenta de que el artículo 196 (ap. 1, segundo párrafo ${ }^{116}$ ) del RGGI exige la previa iniciación del procedimiento sancionador si la responsabilidad tributaria — del art. 41 LGT - incluyera sanciones, otorgándose a los responsables un trámite de audiencia después de que haya recaído la propuesta de resolución del procedimiento sancionador al sujeto infractor, aunque lo cierto es que no se ha plasmado la reivindicación formulada por la doctrina (Pérez Royo 2007: 166) de dar entrada como interesado al presunto responsable [tributario] en el procedimiento seguido para imponer la sanción (ap. 2, tercer párrafo).

115 MARTÍNEZ LAGO, M.A.: «Participación en infracciones y extensión de la responsabilidad a las sanciones tributarias», $Q F$, núm. 15, 2008.

116 Artículo 196 RGGI. Declaración de responsabilidad en el procedimiento inspector. 1. Cuando en el curso de un procedimiento de inspección, el órgano actuante tenga conocimiento de hechos o circunstancias que pudieran determinar la existencia de responsables a los que se refiere el artículo 41 de la Ley 58/2003, de 17 de diciembre, General Tributaria, se podrá acordar el inicio del procedimiento para declarar dicha responsabilidad. El inicio se notificará al obligado tributario con indicación de las obligaciones tributarias y períodos a los que alcance la declaración de responsabilidad y el precepto legal en que se fundamente. Cuando el alcance de la responsabilidad incluya las sanciones será necesario que se haya iniciado previamente el procedimiento sancionador. 


\section{III.7. Limitación temporal para la adopción del acuerdo incoatorio del procedimiento sancionador tributario}

En ese orden de cosas, la redacción del artículo 209.2. ${ }^{\circ}$ de la LGT ha introducido una auténtica limitación para la iniciación del procedimiento sancionador en los casos en los que la infracción se manifiesta en el seno de actuaciones de comprobación e investigación realizadas por los órganos de la inspección, al establecer un plazo máximo para su iniciación —dies ad quem-117, de tres meses desde la fecha en que se hubiera notificado o se entendiese notificada la correspondiente liquidación ${ }^{118}$ o resolución ${ }^{119}$. Este plazo trimestral se computa desde la notificación expresa o presunta - en caso de actas de conformidad - del acto de liquidación hasta la fecha de notificación del inicio del expediente sancionador.

Sostenemos ${ }^{120}$ que el artículo 209.2 de la LGT fija un plazo que es de caducidad, de tres meses para iniciarlo, transcurrido el cual no puede iniciarse ningún expediente sancionador, incluso los derivados de un procedimiento de inspección. El plazo se computa desde que

117 MAGRANER MORENO, F.J. y MARTÍN LÓPEZ, J.: «El límite temporal...», op. cit., pág. 10.

118 Ese límite temporal afecta a los procedimientos sancionadores que se incoen «como consecuencia» de los procedimientos de liquidación o resolución, es decir, que no sólo abarca a las sanciones derivadas de la liquidación o regularización efectuada (infracciones con perjuicio económico de los artículos 191 a 197 LGT), sino a cualquier sanción derivada de una infracción puesta de manifiesto en el curso de los procedimientos de liquidación o resolución (las infracciones por incumplimientos formales de los artículos 198 a 206 LGT)... El incumplimiento del plazo en el procedimiento de gestión - verificación de datos y comprobación limitada-, cuando la finalización del mismo haya superado el plazo de seis meses, producirá la caducidad de dicho procedimiento, sin perjuicio de la posibilidad de iniciar, en su caso, nuevos procedimientos de gestión y sancionador (art. 104.5 LGT). DELGADO SANCHO, C.D.: «Prescripción...», op. cit.

119 JUAN LOZANO, A.M.: «El plazo...», op. cit., págs. 59 y ss; Para FALCÓN Y TELLA la fijación de este plazo implica una decisión presunta de no sancionar, que ha de considerarse firme, y que sólo puede revisarse utilizando los procedimientos especiales de revisión. FALCON Y TELLA, R.: «La nueva regulación...», op. cit., $Q F$, núm. 21, 1998, pág. 7; Para AGUADO I CUDOLÁ, este plazo puede discutirse es un plazo de prescripción de la acción, y no de caducidad, dentro del plazo más amplio de prescripción de la infracción. AGUADO I CUDOLÁ, V.: Prescripción..., op. cit., pág. 153, postura esta última que no exige revisar de oficio la falta de actuación dentro del plazo establecido; Con la caducidad del procedimiento sancionador no solo se archivarán las actuaciones, sino que además se extingue el derecho de la Administración tributaria de sancionar al sujeto pasivo por esa misma actuación que sirvió de base para iniciar el procedimiento ahora caducado. COLLADO YURRITA, M.A. et alii: Derecho Tributario..., op. cit., pág. 300; En ese sentido la STSJ de Madrid de 24 de enero de 2010 (FJ 2. ${ }^{\circ}$ ); También la STSJ de Madrid de 19 de septiembre de 2008 (FJ 4).

120 CALDERÓN GONZÁLEZ, J.M.: «El procedimiento sancionador...», op. cit. 
se hubiera notificado o se entendiese notificada la correspondiente liquidación tributaria. Se trata, por tanto, de un plazo de caducidad y se aplica con independencia de que el actuario haya hecho constar la improcedencia de iniciar el procedimiento sancionador, tal como ha señalado el Tribunal Supremo en Sentencia de 4 de julio de 2005, dictada en el recurso de casación en interés de Ley núm. 91/2003.

Por tanto, el plazo de caducidad para la incoación del procedimiento ${ }^{121}$ se produce respecto de todas y cada una de las infracciones que se proponga liquidar, y por aquellas conductas puestas de manifiesto en el procedimiento de aplicación de los tributos del que el sancionador trae causa.

\section{III.8. Justificación de la limitación temporal para la adopción del acuerdo incoatorio del procedimiento sancionador tributario}

La finalidad de estas normas es evitar una demora en el inicio del expediente sancionador, cuando la Administración tributaria ya ha estimado que existen indicios de una infracción ${ }^{122}$. El modo en que la Ley ha configurado este plazo sin admitir ningún tipo de interrupción ${ }^{123}$, no permite tratarlo como plazo de prescripción de la acción para sancionar, aunque hemos de tener en cuenta que este plazo si podrá suspenderse, así, por ejemplo, en el supuesto en que el órgano de comprobación aprecie indicios de delito y remita el expediente al Ministerio Fiscal ${ }^{124}$.

121 ANÍBARRO PÉREZ y SESMA SÁNCHEZ opinan además que se trata de un plazo de caducidad del ejercicio de la potestad para imponer sanciones tributarias, transcurrido el cual es inviable ejercitar el ius puniendi de la Administración, plazo que tiene carácter preclusivo. En la obra colectiva del Profesor CALVO ORTEGA, R. (dir.): ..., op. cit., págs. 328 y 329.

${ }_{122}$ Sobre la naturaleza de este plazo y su preclusividad puede verse a JUAN LOZANO, A.M. ${ }^{\text {a: }}$ «El plazo para el inicio...», op. cit., págs. 65 y ss.; BLASCO DELGADO, C.: La prescripción..., op. cit., págs. 108 y ss.; MAGRANER MORENO, F.J. y MARTÍN LÓPEZ, J.: «El límite temporal...», op. cit., pág. 6.

${ }^{123}$ No hay identidad en el Derecho tributario, entre la llamada prescripción y la caducidad; la caducidad no admite interrupción del plazo en virtud del cual se produce. El plazo de prescripción, en Derecho tributario, es siempre, susceptible de interrupción. PÉREZ DE AYALA, J.L. y PÉREZ DE AYALA BECERRIL, M.: Fundamentos de Derecho Tributario, Edersa, Dijusa, Madrid, 2004, pág. 230.

124 FALCÓN y TELLA, manifiesta que cuando se aprecian indicios de delito la nueva Ley General Tributaria establece que se debe paralizar el procedimiento sancionador, pero en ningún caso se ordena la paralización del procedimiento inspector sino que simplemente se establece que si se paraliza tal procedimiento (además del sancionador, cuya paralización si resulta obligada), en tal caso cabe ampliar el 
Señala Orón Moratal ${ }^{125}$ que el efecto preclusivo del plazo de tres meses no está previsto para procedimientos tributarios ni tampoco en el régimen administrativo general. Para el autor, constituye un régimen que podemos calificar de privilegiado, y añade la conveniencia de su incorporación al régimen general cuando se proceda a reformarlo en un futuro.

\section{III.9. Procedimientos que pueden ser objeto de caducidad en la incoación de procedimiento sancionador tributario}

En otro orden de cosas, debemos tener en cuenta que los procedimientos a incoar pueden ser varios, y por ello el artículo $22.4 .^{\circ}$ del RGRST contempla que se inicien «tantos procedimientos sancionadores como propuestas de liquidación se hayan dictado, sin perjuicio de los que hayan de iniciarse por las conductas constitutivas de infracción puestas de manifiesto durante el procedimiento y que no impliquen liquidación», aunque, cuando exista identidad en los motivos o circunstancias que determinen la apreciación de varias infracciones, podrán acumularse la iniciación e instrucción de los distintos procedimientos, aunque deba dictarse una resolución individualizada para cada uno de ellos ${ }^{126}$. En idéntico sentido, el ar-

plazo otros doce meses, y si ya se había ampliado, se contara, al menos, con seis meses para finalizar las actuaciones y dictar liquidación. Además, concluye el autor que la paralización no procede salvo que la liquidación este directamente condicionada por el resultado del proceso penal. FALCÓN Y TELLA, R.: «La ejecución de las sentencias penales por la Agencia Tributaria», Quincena Fiscal, núm. 5, 2004, pág. 1.

125 Obra colectiva, ORÓN MORATAL, G. et alii: Nuevo régimen jurídico de los procedimientos tributarios. El procedimiento sancionador, Estudios de Derecho Judicial, Ed. Consejo General del Poder Judicial, Madrid, 2006, pág. 35.

126 De apartado HERMOSÍN extrae, en primer lugar una regla general que consiste en iniciación de tantos procedimientos sancionadores como propuestas de liquidación se hayan dictado. Esta premisa tiene como consecuencia que si la propuesta liquidación afecta a varias obligaciones incumplidas, solo existirá un único procedimiento sancionador para todas ellas. En cambio si hay varias liquidaciones habrá tantos expedientes sancionadores como propuestas de liquidación. También puede darse el caso de que las infracciones derivadas de un procedimiento de aplicación de los tributos no implicaren liquidación. En este caso, se iniciará el correspondiente expediente sancionador por cada una de ellas. No obstante, si concurren identidad de motivos o circunstancias en la apreciación de varias de ellas puede tramitarse un único procedimiento sancionador, aunque deberá dictarse resolución individualizada para cada una de ellas. HERMOSÍN, M.: Procedimiento Sancionador..., op. cit., pág. 149; En aquellos caso en que el alcance del procedimiento de inspección se extienda a varias obligaciones tributarias no existirá un procedimiento por cada obligación tributaria incumplida sino un único procedimiento sancionador por cada acta, sin perjuicio de que en ese procedimiento puedan im-

(C) UNED. Revista de Derecho UNED, núm. 23, 2018 
tículo 25.2. ${ }^{\circ}$ RGRST prevé, para el procedimiento sancionador tramitado de manera separada al de inspección, que se incoen «tantos procedimientos sancionadores como actas de inspección ${ }^{127}$ se hayan incoado, sin perjuicio de los que hayan de iniciarse por las conductas constitutivas de infracción puestas de manifiesto durante el procedimiento inspector y que no impliquen liquidación», pudiendo —no de modo obligado-, cuando exista identidad en los motivos o circunstancias que determinan la apreciación de varias infracciones, acumularse $^{128}$ la iniciación e instrucción de los distintos procedimientos,

poner una o varias sanciones... ES decir no se impone que se adopte una decisión en bloque, en relación con todas las sanciones, sino que podrá decidir de forma separada respecto a cada sanción impuesta que deberá aparecer individualizada en la resolución. MESTRE GARCÍA, E. y CERVANTES SÁNCHEZ-RODRIGO, C.J.: Guía de infracciones..., op. cit., págs. 256, 286 y 287; Según las SsTS de 10 de diciembre de 2009 y 10 de febrero de 2010, en el expediente sancionador han de expresarse todas y cada una de las infracciones cometidas con la sanción que a cada una corresponde: no cabe hacer la suma de las distintas regularizaciones llevadas a cabo en el expediente de gestión, sino que cada una de ellas ha de ser objeto de una valoración distinta y separada. La imposición de una única sanción es una demostración de la falta de comprensión del sistema sancionador, y es errónea la tendencia a identificar el importe de la regularización con la base de la sanción, ya que el importe de la regularización no coincide necesariamente con el importe dejado de ingresar. ZOZAYA MIGUÉLIZ, E.: "Las sanciones, de una en una», Aranzadi Doctrinal, núm. 3, 2010.

Por tanto, es necesario que, respecto a cada partida que ha sido objeto de regularización, se realice un análisis culpabilístico específico y una delimitación cuidadosa del efectivo importe dejado de ingresar en cada caso.

127 El matiz principal es que el mencionado precepto hace referencia a las actas de inspección en lugar de propuestas de liquidación. Así, todos los procedimientos sancionadores se rigen por la misma pauta, a diferencia de lo que sucedía en el régimen anterior. HERMOSÍN, M.: Procedimiento..., op. cit., pág. 149. MESTRE GARCÍA, E. y CERVANTES SÁNCHEZ-RODRIGO, C.J.: Guía de infracciones..., op. cit., págs. 255 a 257. LAMOCA PÉREZ, C.: Infracciones...págs. 472 y 472; En una primera aproximación parece claro que no podrá iniciarse el procedimiento sancionador hasta que se haya incoado la correspondiente acta. No obstante, considero que se está refiriendo a las infracciones que conlleva la propia regularización de la situación tributaria que se plasma en el acta, pensemos por ejemplo en la presunta infracción consistente en realizar declaraciones tributarias falsas o inexactas, es obvio que esta infracción puede ser apreciada por la Inspección como consecuencia de la incoación del acta. Por tanto, no contradice el principio general antes expresado - que nada obsta a que se inicie el procedimiento sancionador sin haber finalizado el de gestión o de comprobación-. RICARDO HOYOS, J.: «El procedimiento...», op. cit., $Q F$, núm. 3, 2001.

${ }_{128}$ La solución que establece el precepto para un supuesto como el referido sería iniciar diversos expedientes sancionadores, que se tramitarían acumuladamente, pero que volverían a desacumularse para que existieran diversas resoluciones sancionadoras que, en caso de ser impugnadas, obligatoriamente deberían acumularse a la impugnación que, en su caso, se hubiera realizado contra la liquidación que derivase del acta. RICARDO HOYOS, J.: «El procedimiento...», op. cit., QF, núm. 3, 2001. 
aunque deberá dictarse una resolución —que termine el procedimiento sancionador - individualizada para cada uno de ellos. En estos procedimientos deberán aparecer debidamente individualizadas las infracciones sancionadas.

\section{III.10. Caducidad en la incoación de procedimiento sancionador tributario y prescripción de la infracción tributaria}

Si bien todo procedimiento caducado, necesariamente no ha prescrito - pues de estar prescrito no podría ejercitarse la potestad sancionadora-, también todo procedimiento prescrito nunca puede caducar - pues no puede incoarse dicho procedimiento, por estar imposibilitado el ejercicio de la potestad sancionadora-.

De cualquier modo, con la articulación actual de los procedimientos de liquidación y sancionador, en donde cualquier actuación - de las que se recogen en el artículo 66.1 LGT- de la administración tiene virtualidad interruptiva, la consecución de estos objetivos no es fácil. No obstante, insistimos en que este plazo, en la generalidad de los casos, puede llegar a superponerse con el plazo de prescripción de la infracción, anulándolo, y que, con independencia de que la responsabilidad tributaria no haya prescrito, no podrá iniciarse el procedimiento sancionador por caducidad.

\section{INEXISTENCIA DE INTERRUPCIÓN DEL PLAZO DE CADUCIDAD ${ }^{129}$}

El principio de no interrupción de la caducidad deviene, para algún autor ${ }^{130}$, la clave de bóveda en la configuración de dicha institu-

129 Ya con la anterior LGT 1963, en el ámbito tributario [se introdujo] una de las grandes notas distintivas de la prescripción extintiva, respecto de la caducidad, y ésta no es otra que la posibilidad de revitalización de los derechos mediante los actos interruptivos de los plazos de que de otro modo conducirían a la ineficacia en el tiempo....Puesto que ya desde la Teoría General del Derecho queda clara la imposibilidad de interrupción de los plazos de caducidad, nos limitamos a recordar otra distinción también suficientemente conocida, pero que siempre conviene tener presente: los diferentes efectos que sobre los plazos de prescripción tienen los supuestos de interrupciones y suspensiones. Ambos hechos tienen como efecto jurídico común la dilatación de los plazos de prescripción. JUAN LOZANO, A.M.: La interrupción de la prescripción tributaria. Análisis de jurisprudencia y doctrina administrativa, Tecnos, Madrid, 1993, págs. 12-13.

130 Recuerda GÓMEZ CORRALIZA, B.: La caducidad. Montecorvo, Madrid, 1990, pág. 255, que el principio de no interrupción de la caducidad se enuncia por primera vez en la literatura jurídica española por ALAS, L., DE BUEN, D. 
ción: el cómputo de los plazos de caducidad no es, en ningún caso, susceptible de interrupción, a diferencia de lo que acaece con los plazos de prescripción, en los que sí es admisible la misma, aunque como veremos aquel instituto admita alguna matización en el ámbito tributario.

El artículo 209.2 de la LGT silencia expresamente la posibilidad de interrupción de su cómputo, extremo éste que afirma su configuración como un plazo de caducidad del ejercicio de la potestad sancionadora de la Administración tributaria y, a su vez, de la negación de su concepción como un plazo de prescripción de la responsabilidad derivada de la comisión de la infracción tributaria. En este sentido, una parte de la doctrina científica civilista ${ }^{131}$ sostiene que la imposibilidad de interrupción del cómputo de los plazos de caducidad no es óbice para que éste sí pueda, excepcionalmente, ser objeto de suspensión. La diferencia entre los conceptos de interrupción y suspensión, más allá de constituir un debate puramente terminológico, ostenta una gran relevancia en la praxis, puesto que el mecanismo de la interrupción implica, de suyo, el reinicio del cómputo del plazo, permitiendo disponer de un nuevo lapso temporal en su integridad, la suspensión únicamente supone la paralización de dicho cómputo, de modo que, periclitada la causa que originó la suspensión, se reanuda el cómputo del plazo, teniéndose en cuenta la totali-

y RAMOS, E.: De la prescripción extintiva. Centro de estudios Históricos, Madrid, 1918, pág. 80, quienes, al preguntarse cómo era posible distinguir si un derecho se encontraba sometido a caducidad o a prescripción, concluían que «si el derecho se extingue fatalmente en el término fijado, es un derecho sujeto a caducidad; si el derecho puede subsistir indefinidamente, mediante la ejecución de actos interruptivos establecidos por la ley, es un derecho sujeto a prescripción»; Esta tesis de la ininterrumpibilidad de los plazos de caducidad fue posteriormente asumida por la práctica totalidad de la doctrina civilista (vid., entre otros, CASTÁN TOBEÑAS, J.: Derecho civil español, común y foral. Tomo I, Volumen 2. ${ }^{\circ}, 10 .^{\mathrm{a}}$ ed., Reus, Madrid, 1963, pág. 852; DÍEZ-PICAZO, L. y GULLÓN BALLESTEROS, A.: Sistema de Derecho Civil. Volumen I, 8. ${ }^{\mathrm{a}}$ ed., Tecnos, Madrid, 1995, págs. 462 a 464; PUIG BRUTAU, J.: Caducidad, prescripción extintiva y usucapión, Bosch, Barcelona, 1988, págs. 70 y ss.), así como por la jurisprudencia del Tribunal Supremo (vid., entre otras muchas, algunas de las Sentencias recogidas en la obra de PUIG BRUTAU, J.: Ibíd., págs. 72 y ss.: Sentencias de 22 de diciembre de 1950, de 15 de diciembre de 1955 de 7 de mayo de 1981 o de 14 de febrero de 1986).

131 Cita AGUADO i CUDOLÁ, cita a PUIG BRUTAU, para quien la "suspensión, ésta puede afectar excepcionalmente a la caducidad». Y, en apoyo de esta exégesis, trae a colación la Sentencia del Tribunal Supremo de 10 de junio de 1985, en la que se asevera que la suspensión del cómputo de los plazos de caducidad acaecerá sólo cuando la Ley así lo prevenga de forma expresa. PUIG BRUTAU, J.: Caducidad, prescripción extintiva y usucapión, Bosch, Barcelona, 1988,pág. 74. 
dad del tiempo transcurrido antes del momento en el cual sobrevino la misma ${ }^{132}$.

De este modo, concluida la incontestable ininterrumpibilidad ${ }^{133}$ del plazo trimestral de incoación de los procedimientos sancionadores tributarios prevista en el artículo 209.2 de la LGT, cabe seguidamente plantearse si es factible, en algún supuesto excepcional, la suspensión de su cómputo ${ }^{134}$. Pues bien, la respuesta a tal

132 Según PUIG BRUTAU, «en la suspensión el transcurso del plazo de prescripción queda paralizado o detenido, pero cuando desaparece la causa que la ha producido no se ha de volver a contar el plazo desde el principio, sino que reanuda su marcha a partir del momento en que se había detenido y el tiempo posterior se suma al anterior que ya había transcurrido a efectos de completar el plazo. En cambio, cuando concurre una causa de interrupción de la prescripción, el tiempo transcurrido queda completamente borrado y ha de empezarse a contar de nuevo desde el principio hasta completarlo por entero". PUIG BRUTAU, J.: Caducidad, prescripción extintiva y usucapión, Bosch, Barcelona, 1988, pág. 71; En esta misma línea interpretativa, GÓMEZ CORRALIZA, al distinguir entre interrupción y suspensión, afirma que la primera «tiene lugar cuando concurre una determinada circunstancia tipificada por la Ley que anula o hace inútil el tiempo transcurrido de modo tal que el plazo ha de empezar a contarse de nuevo»; la segunda, por el contrario, "supone un mero detenimiento o paralización del cómputo del tiempo». GÓMEZ CORRALIZA, B.: La caducidad, Montecorvo, Madrid, 1990, pág. 254.

${ }^{133}$ Las actuaciones que realice la Administración tributaria en el seno de los diferentes procedimientos de aplicación de los tributos no tienen eficacia suspensiva de la caducidad ALONSO ARCE, I.: «La caducidad...», op. cit., JT, núm. 9, 2005, pág. 2.

${ }^{134}$ En materia de caducidad, a diferencia de lo que acontece con la prescripción, no cabe interrupción, sino suspensión del mismo, tal y como se dice en el art. 42.5 LRJPAC [hoy art. 22.1 de la Ley 39/2015, de 1 de octubre, del Procedimiento Administrativo Común de las Administraciones Públicas LPACAP], esto es, el cómputo puede detenerse por causas legales, pero luego continúa desde donde había llegado. GARCÍA GÓMEZ DE MERCADO, F.: Sanciones administrativas. Garantías, derechos y recursos del presunto responsable, Comares, Granada, 2004, pág. 233; La LRJPAC utiliza(ba) incorrectamente el término interrupción en dos ocasiones: por un lado, cuando el art. 44.2.II determina(ba) [hoy superado en parte por el art. 22.1.a LPACAP, aunque sigue incidiéndose en dicha incorrección en el art. 25.2 LPACAP] que la paralización del procedimiento por causas imputables al interesado "interrumpirá el cómputo del plazo para resolver y notificar la resolución”, y por otro, cuando el art. 83.3 [hoy corregido en el art. 22.1.d LPACAP] dispon(ía) que la no emisión de informes preceptivos que sean determinantes para la resolución del procedimiento 'podrá interrumpir el plazo de los trámites sucesivos'. Pues bien en ambas ocasiones hay que entender que no se trata de verdadera 'interrupción', sino de suspensión del plazo, de manera que éste prosigue su cómputo una vez que el interesado cumpla con el trámite necesario o se emita el correspondiente informe. En el mismo error incid(ía) el art. 20.6 del RD 1398/1993, cuando se refiere a las posibles interrupciones del cómputo de la caducidad por causas imputables a los interesados o por la suspensión del procedimiento sancionador cuando se esté tramitando otro, por los mismo hechos, ante los órganos comunitarios europeos o ante la jurisdicción penal (arts. 5 y 7 RD 1398/1993). DE DIEGO DÍEZ, L.A.: ..., op. cit., págs. 203204; En este sentido la STSJ Navarra 25.09.2003. 
cuestión no puede sino ser positiva en el particular caso de que, finalizado uno de los procedimientos a que refiere el precepto, y con carácter previo al inicio del oportuno expediente sancionador, la Administración tributaria apreciase indicios de delito contra la Hacienda Pública ${ }^{135}$. Efectivamente, en tal hipótesis, la preceptiva remisión del tanto de culpa a la jurisdicción penal ha de acarrear ineluctablemente la suspensión del cómputo del plazo de caducidad de tres meses para la incoación del procedimiento sancionador tributario, cómputo éste que deberá reemprenderse en el supuesto de sobreseimiento de la causa penal, gozando la Administración tributaria, para iniciar el expediente sancionador, únicamente del tiempo resultante de restar a dicho plazo de tres meses la fracción de éste ya consumida hasta el acaecimiento de la causa suspensiva.

Destacamos, en el caso de actas con acuerdo, que el período de interrupción justificada en el cómputo del plazo del procedimiento de aplicación de los tributos - y no en el sancionador-, comprende el tiempo transcurrido desde la fecha del primer intento de notificación del inicio del procedimiento sancionador de manera conjunta, debidamente acreditado, hasta la fecha en que dicha notificación se entienda producida, con los efectos dispuestos en el artículo 104.2 de la Ley 58/2003, de 17 de diciembre, General Tributaria, lo que no resulta en modo alguno beneficioso para el obligado tributario, produciéndose un efecto inverso de traslación de la interrupción desde el procedimiento sancionador tributario al procedimiento de aplicación de los tributos. En estos casos lo que en realidad está consintiendo la norma reglamentaria sancionadora es que la dificultad de notificar el inicio del procedimiento sancionador constituya una interrupción justificada de las actuaciones inspectoras, y ello aunque materialmente prosigan.

Por su parte, el plazo de caducidad en la terminación a que refiere el artículo 211.2. ${ }^{\circ}$ LGT, no admite interrupción ni suspensión ${ }^{136}$,

135 MAGRANER MORENO, F.J. Y MARTÍN LÓPEZ, J.: «El límite temporal...», op. cit., pág. 12; La suspensión no inhabilita el tiempo transcurrido con anterioridad a la concurrencia de la causa suspensiva. MARTÍN FERNÁNDEZ, F.J. y RODRÍGUEZ MÁRQUEZ, J.: «La interpretación administrativa de la Ley de Derechos y Garantías de los Contribuyentes», QF, núm. 8, 1999.

136 ESEVERRI expresa que «en cualquier caso, su vencimiento es inexorable, no se puede interrumpir», sin matices. ESEVERRI..., 2011, op. cit., pág. 463. 
como señalan los arts. $250.2^{\circ 137}, 252.2 .^{\circ} .3^{138}$ y $253.1 .^{\circ}$ in fine ${ }^{139} \mathrm{de} \mathrm{la}$ LGT $^{140}$, y el desarrollo que a dichos artículos se ha dado en los artículos 32 y 33 del RGRST. En cualquier otro caso diferente al del delito fiscal, el procedimiento deberá terminar dentro del plazo de seis meses desde que se notifique su iniciación, mediante resolución expresa $^{141}$, cuyo contenido será el legislado en el artículo 211.3. ${ }^{\circ}$, que

137 En los supuestos a los que se refiere este apartado, la Administración se abstendrá de iniciar o, en su caso, continuar, el procedimiento sancionador correspondiente a estos mismos hechos. En caso de haberse iniciado un procedimiento sancionador, de no haber concluido éste con anterioridad, dicha conclusión se entenderá producida, en todo caso, en el momento en que se pase el tanto de culpa a la jurisdicción competente o se remita el expediente al Ministerio Fiscal, sin perjuicio de la posibilidad de iniciar un nuevo procedimiento sancionador en los casos a que se refiere el último párrafo de este apartado. La sentencia condenatoria de la autoridad judicial impedirá la imposición de sanción administrativa por los mismos hechos. De no haberse apreciado la existencia de delito, la Administración Tributaria iniciará, "cuando proceda», el procedimiento sancionador administrativo de acuerdo con los hechos que los tribunales hubieran considerado probados.

${ }^{138}$ El pase del tanto de culpa o la remisión del expediente interrumpirá los plazos de prescripción del derecho a determinar la deuda tributaria y a imponer la sanción, de acuerdo con lo previsto en los artículos 68.1 y 189.3 de esta Ley.

139 Según el art. 253.2..$^{\circ}$ in fine LGT «2. La inadmisión de la denuncia o querella determinará..... En estos casos se iniciará el cómputo de los plazos de prescripción del derecho a determinar la deuda y a imponer la sanción de acuerdo con lo indicado en el artículo 68.7 de esta Ley». En igual sentido el art. 257. 2. ${ }^{\circ}$ in fine LGT que prevé «[e]n estos casos se iniciará el cómputo del plazo de prescripción del derecho a determinar la deuda y a imponer la sanción de acuerdo con lo indicado en el artículo 68.7 de esta Ley». Por nuestro lado, consideramos un tanto confusa la interrupción del lapso prescriptivo que recogen estos preceptos, pues lo correcto, si se pretende que estas actuaciones penales interrumpan la prescripción del procedimiento sancionador, sería que se hubiere efectuado remisión a lo dispuesto en el art. 189.3.b) LGT que prevé «El plazo de prescripción para imponer sanciones tributarias se interrumpirá:... b) Por la interposición de reclamaciones o recursos de cualquier clase, por la remisión del tanto de culpa a la jurisdicción penal, así como por las actuaciones realizadas con conocimiento formal del obligado en el curso de dichos procedimientos.»

${ }^{140}$ Dicho precepto prevé la suspensión del procedimiento sancionador tributario por el pase del tanto de culpa a la jurisdicción competente, o remisión del expediente al Ministerio Fiscal; Si bien la caducidad no es susceptible de interrupción, cabe decir que alguna legislación viene admitiendo ciertos supuestos la posibilidad de suspender los plazos de caducidad. Esta posibilidad comporta que el plazo quede paralizado, de tal forma que cuando desaparece la causa que motivó la suspensión, se vuelve a contar teniendo en cuenta el tiempo anteriormente transcurrido. AGUADO I CUDOLÀ, V.: Prescripción..., op. cit., pág. 38; SE advierte que sólo se recoge en el Reglamento Sancionador y no en la LGT. HERRERO DE EGAÑA Y ESPINOSA DE LOS MONTEROS, J.M. (coord.): Comentarios...,op. cit. Vol.II, Aranzadi, Pamplona, 2004, pág. 1410.

${ }_{141}$ Aunque no sea un supuesto de suspensión o de interrupción, el art. 24.1 del RGRST prevé que, con anterioridad a la resolución del expediente, el órgano que tiene competencia para resolver pueda ordenar que se amplíen las actuaciones practicadas, y por esta vía rectificar la propuesta de resolución formulada por el ór-

(C) UNED. Revista de Derecho UNED, núm. 23, 2018 
es el propio de un acto finalizador del procedimiento sancionador. De este modo, «fijará los hechos, la valoración de las pruebas practicadas, la determinación de la infracción cometida, la identificación de la persona o entidad infractora y la cuantificación de la sanción que se impone, con indicación de los criterios de graduación de la misma y de la reducción que proceda de acuerdo con lo previsto en el artículo 188 de esta ley. En su caso, contendrá la declaración de inexistencia de infracción o responsabilidad».

Algún autor ${ }^{142}$, pese a la ausencia de norma legal y reglamentaria que lo contemple de forma expresa, entiende que cabe la posibilidad de que se suspenda el plazo de resolución de un procedimiento sancionador si concurre alguna de las circunstancias que, según el artículo 22.1 LPACAP — que recoge la suspensión procedimental potestativa- [con anterioridad art. 42.5 de la extinta Ley 30/1992, de 26 de noviembre, de Régimen Jurídico de las Administraciones Públicas y del Procedimiento Administrativo Común —LRJPAC-] y también la del art. 22.2 LPACAP — con suspensión procedimental obligada-, enervan el deber de resolver que recae sobre la Administración, argumento que no compartimos por lo antes indicado. En estos casos, se tratará de un supuesto equivalente a la interrupción justificada que, al igual que aquellas demoras imputables al contribuyente, pueden descontarse del tiempo invertido en la tramitación de un procedimiento sancionador. Es decir, nos encontramos ante lo que podemos considerar como un tiempo asociado a la realización de alguna actuación extraordinaria y objetivamente necesaria para la adecuada decisión del caso y, por ello, en la medida en que su realización no es discrecional para el órgano responsable de la instrucción del procedimiento debe excluirse del cómputo del plazo legal para resolver. Ese mismo autor, ante el silencio de la normativa tributaria, se plantea si resulta de aplicación al procedimiento

gano instructor. Esta ampliación de actuaciones no tiene cobertura legal —salvo para los expedientes sancionadores derivados de un procedimiento de inspección-, teniendo carácter preceptivo siempre que en el expediente vayan a tenerse en cuenta hechos distintos a los que obren en él. La norma reglamentaria no fija plazo máximo para la ampliación de actuaciones pero es evidente que, en todo caso, deberán desarrollarse dentro del plazo máximo de resolución del procedimiento sancionador (6 meses). ANÍBARRO PÉREZ, S. y SESMA SÁNCHEZ, B.: Infracciones..., op. cit., págs. 220 y 221; también en la obra colectiva del Profesor CALVO ORTEGA, R. (dir.): ..., op. cit., págs. 344 a 345; De opuesta opinión son MESTRE GARCÍA, E. y CERVANTES SÁNCHEZ-RODRIGO, C.J.: Guía de infracciones..., op. cit., pág. 280, que encuentran sentido a esta previsión al ponerla en relación con el art. 24.1.2. ${ }^{\circ}$ del RGRST, pues para poder tener en cuenta un hecho, documento o prueba que no esté incorporado al expediente cuando éste pase al órgano competente para resolver será necesario ampliar las actuaciones para su incorporación.

142 IGLESIAS CAPELLAS, J.: «La caducidad...», op. cit., pág. 286, tomo I. 
sancionador tributario la regla general contenida en el artículo 23 LPACAP [anterior art. 42.6 de la derogada LRJPAC] en virtud de la cual puede ampliarse el plazo de resolución de los procedimientos administrativos. Aunque ciertamente no existe un precepto concreto en el que sostener la inaplicación de esta regla al procedimiento sancionador tributario, entendemos que respecto a esta cuestión no cabe una aplicación supletoria del régimen general, por cuanto el artículo 211.2 LGT regula expresamente la duración de los procedimientos sancionadores tributarios sin contemplar tal posibilidad ${ }^{143}$. Otra cosa distinta es la ampliación de los plazos concedidos al interesado para realizar alguna actuación en el procedimiento que, de concederse, constituiría un supuesto de dilación no imputable a la Administración en los términos ya expuestos.

No existe, salvo en ciertos casos del procedimiento de inspección tributaria, un plazo máximo para la ampliación de las actuaciones (en el extinto RGGI/86 art. 63 bis 8, el plazo fijado en el artículo era de tres meses), por lo que el plazo máximo de resolución del expediente conforme a la LGT art. 211.2 y el RSAN art. $24.4^{144}$ es de seis meses $^{145}$. En este sentido, incluso el RSAN art. 25, relativo al procedimiento sancionador derivado de un procedimiento de inspección, al referirse a la rectificación del expediente o la ampliación de actuaciones que pueda ordenarse en el plazo de un mes a partir de la

${ }^{143} \mathrm{Si}$ bien es cierto que el art. 211.2.2. ${ }^{\circ}$ LGT norma que "[c]uando habiéndose iniciado el procedimiento sancionador concurra en el procedimiento inspector del que trae causa alguna de las circunstancias previstas en el apartado 5 del artículo 150 de esta Ley (ampliación por tres o seis meses el plazo resolutivo, justificado en la aportación extemporánea de documentación por el obligado), el plazo para concluir el procedimiento sancionador se extenderá por el mismo periodo (tres o seis meses) que resulte procedente de acuerdo con lo dispuesto en dicho apartado». Desde nuestro punto de vista no tiene sentido el presente precepto en aquellos casos en que el procedimiento sancionador se haya iniciado una vez terminado el procedimiento inspector, pues, una vez concluido un procedimiento inspector e incoado con posterioridad un procedimiento sancionador tributario ¿qué aporta al procedimiento sancionador una aportación documental extemporánea en un procedimiento inspector ya resuelto?, es más, ¿porqué debe ampliarse el plazo de caducidad en la terminación del procedimiento sancionador durante tres o seis meses, si ninguna relación tiene dicha circunstancia en el procedimiento sancionador tributario?

${ }_{144}$ Dicho apartado ha sido derogado por el RD 1072/2017, que modifica el RSAN, en vigor con carácter general a partir del 1-1-2018.

${ }^{145}$ El TEAC 12-7-06 estimó el recurso extraordinario de alzada para unificación de criterio declarando que los procedimientos sancionadores en materia tributaria a los que se refiere la DG AEAT Instr 9/2003 deberán concluir antes de 31-12-2004, sin que les resulte de aplicación el plazo máximo de resolución previsto de 6 meses. En igual sentido el TEAC 12-7-07. 
firma del acta en conformidad, señala que éstas deberán desarrollarse "dentro del plazo máximo de duración del procedimiento» ${ }^{146}$.

Ni la LGT ni el Reglamento, salvo por razón de la remisión del expediente al Ministerio Fiscal o a los Tribunales (LGT art. 180 y RSAN art. 32), contemplan causa alguna de interrupción o suspensión del plazo de terminación del procedimiento sancionador.

Dicho lo anterior, no es menos cierto que la LGT art. 211.2.2. ${ }^{\circ}$ norma la posibilidad de extensión del procedimiento sancionador "[c]uando habiéndose iniciado el procedimiento sancionador concurra en el procedimiento inspector del que trae causa alguna de las circunstancias previstas en el apartado 5 del artículo 150 de esta Ley (ampliación por tres o seis meses el plazo resolutivo, justificado en la aportación extemporánea de documentación por el obligado), el plazo para concluir el procedimiento sancionador se extenderá por el mismo periodo (tres o seis meses) que resulte procedente de acuerdo con lo dispuesto en dicho apartado».

Desde nuestro punto de vista no tiene sentido el citado precepto en aquellos casos en que el procedimiento sancionador se haya iniciado una vez terminado el procedimiento inspector, pues, una vez concluido dicho procedimiento de aplicación de los tributos e incoado con posterioridad un procedimiento sancionador tributario ¿qué aporta al procedimiento sancionador una aportación documental extemporánea en un procedimiento inspector ya resuelto?, es más, ¿por qué debe ampliarse el plazo de caducidad en la terminación del procedimiento sancionador durante tres o seis meses, si ninguna relación tiene dicha circunstancia en el procedimiento sancionador tributario? Por todo ello entendemos que la ampliación del plazo de caducidad en la terminación del procedimiento sancionador, únicamente puede tener cabida, cuanto más, en aquellos supuestos en los que se haya incoado el procedimiento sancionador tributario antes de la resolución del procedimiento inspector, sólo de ese modo tiene sentido que la LGT art. 211.2 diga «...el plazo para concluir el procedimiento sancionador se extenderá por el mismo periodo que resulte procedente de acuerdo con lo dispuesto en dicho apartado», es decir, ambos procedimientos tienen que existir simultáneamente, y no consecutivamente.

146 Sin embargo, es posible considerar la interrupción o suspensión del plazo de duración del procedimiento sancionador por la remisión que establece el RSAN art. 24 a la LGT art. 211.2, CALDERÓN GONZÁLEZ, J.M.: «El procedimiento sancionador...», op. cit. Remisión que, no obstante, con efectos a partir del 1-1-2018 desaparece de la regulación reglamentaria, al derogarse el RSAN art. 24.4 por el RD 1072/2017. 
En estos casos, cuando durante el desarrollo del procedimiento inspector - tramitado simultáneamente con el procedimiento sancionador tributario- el obligado tributario — que deberá coincidir con el presunto infractor tributario- manifieste que no tiene o no va a aportar la información o documentación solicitada o no la aporta íntegramente en el plazo concedido en el tercer requerimiento, su aportación posterior determinará la extensión del plazo máximo de duración del procedimiento inspector - y el de terminación del procedimiento sancionador tributario- por un período de tres meses.

Sin embargo no resultará de aplicación al procedimiento sancionador la expresión «siempre que dicha aportación se produzca una vez transcurrido al menos nueve meses desde su inicio» (LGT art. 211.2.2. ${ }^{\circ}$ ), y ello por que tanto la manifestación del obligado como la aportación documental deberá de haber acontecido antes de que transcurran 6 meses, pues la aportación documental entre el mes 6 y el mes 9 en modo alguno podría tener efectos en un procedimiento sancionador que, de no haberse resuelto expresamente, estaría caducado sin posibilidad de reapertura ulterior.

No obstante, la extensión será de seis meses cuando la aportación se efectúe tras la formalización del acta y determine que el órgano competente para liquidar acuerde la práctica de actuaciones comple-

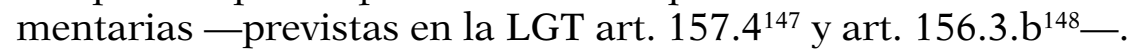

Asimismo, el plazo máximo de duración del procedimiento inspector se extenderá por un periodo de seis meses cuando tras dejar constancia de la apreciación de las circunstancias determinantes de la aplicación del método de estimación indirecta, se aporten datos, documentos o pruebas relacionados con dichas circunstancias.

Por su parte, el RD 1072/2017 de modificación del RSAN introduce, con efectos a partir del 1-1-2018 un nuevo apartado 4 en el art. 25, renumerándose los actuales apartados 4 a 7 como apartados 5 a 8, respectivamente, con la siguiente redacción: «4. En caso de retraso producido en el procedimiento sancionador como conse-

147 La LGT art. 157: Antes de dictar el acto de liquidación, el órgano competente podrá acordar la práctica de actuaciones complementarias en los términos que se fijen reglamentariamente, previstos en el RGGI art. 187.3.c y 188.4.

${ }^{148}$ La LGT art. 156.3.b: Se entenderá producida y notificada la liquidación tributaria de acuerdo con la propuesta formulada en el acta si, en el plazo de un mes contado desde el día siguiente a la fecha del acta, no se hubiera notificado al interesado acuerdo del órgano competente para liquidar, con alguno de los siguientes contenidos: ... b) Ordenando completar el expediente mediante la realización de las actuaciones que procedan. 
cuencia de la orden de completar el expediente del procedimiento inspector a la que se refiere la LGT art. 156.3.b) y 157.4, se computará (como) una dilación en el procedimiento sancionador «derivado" del procedimiento inspector que se hubiera iniciado, desde el día siguiente a aquel en el que se dicte la orden de completar hasta que se notifique la nueva acta que sustituya a la anteriormente formalizada o se le dé trámite de audiencia en caso de que no sea necesario incoar una nueva acta.» Como hemos indicado, dicho apartado no tiene ningún sentido en el supuesto de un procedimiento sancionador que se inicia una vez terminado un procedimiento inspector. Aún más, la LGT, en sus arts. 209.2 o 211.2, no contemplan interrupción justificada ni injustificada alguna, por lo que, teniendo en cuenta que el título III LGT únicamente se aplica a los procedimientos de aplicación de los tributos, ex arts. 83.1 y 97, y considerando que no existe remisión alguna al art. 104 LGT en la interrupción de la caducidad del procedimiento sancionador tributario - que se encuadra en diferente Título legal, el IV y no el III-, no podemos encontrar admisible ni legal, que una disposición reglamentaria recoja un supuesto de interrupción justificada con la finalidad de alargar un plazo legal de terminación de un procedimiento sancionador tributario, con lo que dicho precepto reglamentario no es sino una extralimitación legislativa que la exposición de motivos ${ }^{149}$ del Real Decreto 1072/2017, de 29 de diciembre, por el que se modifica el Reglamento general del régimen sancionador tributario, aprobado por el Real Decreto 2063/2004, de 15 de octubre, justifica con una simple "[e]n el cómputo del plazo de renuncia a la tramitación separada en el procedimiento sancionador no se deducirán las dilaciones no imputables a la Administración y las interrupciones justificadas. Tampoco en el procedimiento inspector los supuestos de suspensión y de extensión del plazo.» Así las cosas, no existiendo causa de interrupción alguna del procedimiento sancionador tributario por remisión a las circunstancias que se norman en los arts. 156.3.b) y 157.4 LGT, no resulta correcta la regulación realizada de manera reglamentaria, debiendo considerarse un exceso del poder ejecutivo sin amparo legal.

${ }^{149}$ Recordemos que dicha exposición de motivos justifica que «[e]n los supuestos de tramitación conjunta del procedimiento sancionador y del procedimiento de aplicación de los tributos es preciso notificar de forma separada el inicio del procedimiento sancionador para que posteriormente ambos procedimientos se tramiten de forma conjunta. La redacción vigente establece que el tiempo que transcurra desde el primer intento de notificación del inicio del procedimiento sancionador hasta que se entienda éste notificado se considera interrupción justificada. Al eliminarse del procedimiento de inspección las interrupciones justificadas, es preciso adecuar el artículo a la nueva normativa.» 
Diferente al anterior caso, se constata en la LGT art. 250.2, cuando prevé la conclusión del procedimiento sancionador tributario incoado en los casos en que se aprecien indicios de delito contra la Hacienda Pública «sin perjuicio de que se pase el tanto de culpa a la jurisdicción competente o se remita el expediente al Ministerio Fiscal», es decir, que parece que baste la apreciación de delito fiscal para que deba de «concluirse» el procedimiento sancionador, lo cual entendemos que resulta absolutamente arbitrario.

A mejor conclusión se llega en el RSAN art. $32^{150}$ y $33^{151}$ modificados por el RD 1072/2017 152 , en vigor a partir del 1-1-2018. En dichos preceptos expresamente prevé que únicamente resulte posible la conclusión y archivo del expediente sancionador tributario incoado,

150 RSAN art. 32. Actuaciones en supuestos de los delitos previstos en el CP arts. 305 y 305 bis. "1. En el supuesto de que la Administración tributaria considere que la conducta del obligado tributario pudiera ser constitutiva del delito tipificado en los artículos 305 o 305 bis del Código Penal, el pase del tanto de culpa a la jurisdicción competente o la remisión del expediente al Ministerio Fiscal producirá las siguientes consecuencias: a) En caso de no haberse iniciado un procedimiento sancionador por los mismos hechos, la Administración tributaria se abstendrá de iniciar el mismo. b) En caso de que dicho procedimiento ya se hubiera iniciado, la Administración tributaria se abstendrá de continuar su tramitación, entendiéndose concluido. c) En caso de haberse impuesto sanción tributaria por los mismos hechos, se suspenderá su ejecución. Estas mismas consecuencias se producirán, cuando la Administración tributaria tenga conocimiento de que se está desarrollando un proceso penal sobre los mismos hechos. Lo dispuesto en este apartado se entenderá sin perjuicio de la posibilidad de iniciar un nuevo procedimiento sancionador o, en su caso, de reanudar la ejecución de la sanción administrativa previamente suspendida, en los casos en que no se hubiera apreciado la existencia de delito, de acuerdo con los hechos que los tribunales hubieran considerado probados. 2. La sentencia condenatoria de la autoridad judicial impedirá la imposición de sanción administrativa por los mismos hechos».

151 RSAN art. 33: «1. En los supuestos en que la Administración tributaria estime que la infracción cometida pudiera ser constitutiva del delito previsto en el artículo 310 del Código Penal, se procederá conforme a lo dispuesto en el artículo anterior, sin que sea posible iniciar o continuar el procedimiento para la imposición de sanciones por los mismos hechos y sin que éstos puedan ser tenidos en cuenta para la calificación de las infracciones tributarias cometidas. En los supuestos previstos en este apartado, de no haberse apreciado la existencia de delito, la Administración tributaria podrá iniciar el procedimiento sancionador de acuerdo con los hechos que los tribunales hubieran considerado probados. 2. En los supuestos en que la Administración tributaria estime que en los hechos descubiertos pudieran existir indicios de haberse cometido alguno de los delitos previstos en los artículos 306 a 308 del Código Penal, hará constar en diligencia los hechos y circunstancias concurrentes e informará de ello al órgano administrativo competente para efectuar la correspondiente comprobación. No obstante, cuando se trate de subvenciones cuya comprobación corresponda a la Agencia Estatal de Administración Tributaria, se procederá conforme a lo dispuesto en el artículo anterior».

152 Informado al público el 30-6-2017. 
cuando ya se haya pasado el tanto de culpa a la jurisdicción competente o ya se hubiera remitido el expediente al Ministerio Fiscal.

Mayores dudas nos suscita cuando el archivo de actuaciones sancionadoras se ha de entender implícito — sin resolución algunacuando se remitan las actuaciones a la jurisdicción penal o a Fiscalía, pues el traslado - previo trámite de audiencia y autorización del órgano tributario correspondiente- de las actuaciones a la jurisdicción penal se ha de comunicar - aunque no se diga muy claramente- al presunto infractor (LGT art. 253.1), y la presentación de querella o la denuncia formulada ante un órgano judicial, en la que se atribuya a una persona determinada su presunta participación en un hecho que pueda ser constitutivo de delito, suspenderá el cómputo de la prescripción (del delito) por un plazo máximo de seis meses, a contar desde la misma fecha de presentación de la querella o de formulación de la denuncia. Si dentro de dicho plazo se dicta contra el querellado o denunciado, o contra cualquier otra persona implicada en los hechos, alguna de las resoluciones judiciales mencionadas en el CP art. 132.2 regla $1 .^{\text {a }}$ (resolución penal atributiva de presunta participación en el presunto delito), la interrupción de la prescripción se entenderá retroactivamente producida, a todos los efectos, en la fecha de presentación de la querella o denuncia. Por el contrario, el cómputo del término de prescripción - y también el plazo de caducidad en la terminación del procedimiento sancionador- «continuará» desde la fecha de presentación de la querella o denuncia si, dentro del plazo de seis meses, recae resolución judicial firme de inadmisión a trámite de la querella o denuncia o por la que se acuerde no dirigir el procedimiento contra la persona querellada o denunciada. La «continuación» del cómputo - prescriptivo y, aunque no se diga, de caducidad en la terminación del procedimiento sancionador - se producirá también si, dentro de dicho plazo, el juez de instrucción no adoptara ninguna de las resoluciones previstas en el CP art. 132.

Únicamente en el caso de no haberse apreciado la existencia de delito, la Administración Tributaria iniciará, cuando proceda, el procedimiento sancionador administrativo (tributario) de acuerdo con los hechos que los tribunales hubieran considerado probados (LGT art. 250.2).

Por otro lado, en los supuestos previstos en la LGT art. 251.1 (excepciones a la liquidación administrativa de los elementos de la obligación tributaria defraudada), y en caso de que se hubiera iniciado un procedimiento sancionador tributario, éste 'se entenderá' «concluido», en todo caso, «en el momento en que se pase» el tanto 
de culpa a la jurisdicción competente «o se remita el expediente» al Ministerio Fiscal, sin perjuicio de la posibilidad de iniciar un nuevo procedimiento sancionador si finalmente no se apreciara delito y de acuerdo con los hechos que, en su caso, los tribunales hubieran considerado probados, esto es, no antes de que la autoridad judicial dicte sentencia firme, tenga lugar el sobreseimiento o el archivo de las actuaciones o se produzca la devolución del expediente por el Ministerio Fiscal.

El pase del tanto de culpa o la remisión del expediente interrumpirá los plazos de prescripción del derecho a determinar la deuda tributaria y a imponer la sanción, de acuerdo con lo previsto en la LGT arts. 68.1 y 189.3 .

La sentencia condenatoria de la autoridad judicial impedirá la imposición de sanción administrativa por los mismos hechos.

Las actuaciones del procedimiento de comprobación e investigación realizadas durante el periodo de suspensión respecto de los hechos denunciados se tendrán por inexistentes.

En los casos en que la Administración Tributaria aprecie «indicios» de delito contra la Hacienda Pública y no concurran las circunstancias que impiden dictar liquidación de los elementos de la obligación tributaria defraudada ex LGT art. 251.1, se notificará propuesta de liquidación vinculada a delito y otorgará trámite de audiencia por 15 días naturales, tras el cual el órgano tributario competente resolverá, en su caso, las alegaciones presentadas y dictará una liquidación administrativa, con la autorización previa o simultánea del órgano de la Administración Tributaria competente para interponer la denuncia o querella, "cuando considere» que la regularización procedente pone de manifiesto la existencia de un posible delito contra la Hacienda Pública, pasando el tanto de culpa a la jurisdicción competente o remitiendo el expediente al Ministerio Fiscal finalizando así el procedimiento respecto de lo regularizado mediante dicha liquidación, liquidación que deberá ser notificada al obligado tributario de la misma (LGT art. 253.1).

El pase del tanto de culpa o la remisión del expediente interrumpirá los plazos de prescripción del derecho a determinar la deuda tributaria y a imponer la sanción, de acuerdo con lo previsto en la LGT arts. 68.1 y 189.3 .

De conformidad con lo dispuesto en la LGT 257.2.c, dictada en el proceso penal resolución firme, sin que aprecie delito por motivo diferente a la inexistencia de la obligación tributaria, se iniciará 
el cómputo del plazo de prescripción del derecho a determinar la deuda y a imponer la sanción de acuerdo con lo indicado en la LGT art. 68.7. De este modo el plazo de prescripción interrumpido por el ejercicio de acciones penales, por la remisión del tanto de culpa a la jurisdicción competente o la presentación de denuncia ante el Ministerio Fiscal o por la recepción de una comunicación judicial de paralización del procedimiento, se iniciará de nuevo cuando la Administración tributaria reciba la notificación de la resolución firme que ponga fin al proceso judicial o que levante la paralización, o cuando se reciba la notificación del Ministerio Fiscal devolviendo el expediente. Por nuestra parte, observamos que, más que iniciarse de nuevo, debemos entender que la resolución penal firme volverá a interrumpir el plazo prescriptivo anteriormente interrumpido por el ejercicio de las acciones penales oportunas.

\section{IV.1. Modo de notificación de la terminación del procedimiento sancionador tributario}

En cuanto a la forma de efectuar la notificación ${ }^{153}$, también considera cumplida la obligación de notificar y de computar el plazo de (terminación) resolución, siempre que se sigan las reglas contenidas en la LGT art. $104.2^{154}$.

${ }^{153}$ Hemos de entender que este modo de notificar resulta excepcional a la vista de lo dispuesto en la LGT art. 208.4, que se remite a los art. 109 a 112 LGT, y no al art. 104.2. ${ }^{\circ}$ LAMOCA se pregunta si la remisión del art. $211.2 \mathrm{al}$ art. 104.2. ${ }^{\circ}$, y la de este último al desarrollo reglamentario, debe entenderse hecha, en materia sancionadora, al desarrollo reglamentario sancionador, o debe entenderse hecha también al RGGI, en aquellas no previstas en el RSAN. Entiende el autor que si resultan de aplicación las causas de interrupción justificada y por causa no imputable a la Administración del RGGI. LAMOCA PÉREZ,C.: Infracciones..., op. cit., págs. 456 y 457. No obstante se aplica la regla de prevalencia del RSAN sobre el RGGI que se contiene en el RGGI art. 1.3. Asimismo este modo de notificar no resulta de aplicación al acuerdo de incoación que establece en la LGT art. 209.1 y el RSAN art. 22, ni en los diferentes trámites de la instrucción de la LGT art. 210.

DÍEZ OCHOA considera que las dilaciones no imputables a que refiere la LGT art. 104.2 únicamente cabría admitir la solicitud de ampliación de plazo para formular alegaciones o dificultades originadas en la notificación de actuaciones motivadas por el propio interesado. DÍEZ OCHOA, J.M.: Derecho Tributario..., op. cit., págs. 534 a 535 .

${ }^{154}$ Cuando el precepto se remite a la LGT art. 104.2 se remite tanto a la causa de interrupción de su primer párrafo como a las del segundo párrafo que indica " los períodos de interrupción justificada que se especifiquen reglamentariamente y las dilaciones en el procedimiento por causa no imputable a la Administración tributaria no se incluirán en el cómputo del plazo de resolución.». MESTRE GARCÍA, E. y CERVANTES SÁNCHEZ-RODRIGO, C.J.: Guía de infracciones..., op. cit., pág. 284; Los períodos de dilación por causa no imputable a la Administración se- 
Conforme a la LGT art. 104.2. ${ }^{\mathrm{a}}$, "a los solos efectos de entender cumplida la obligación de notificar dentro del plazo máximo de duración de los procedimientos — de aplicación de los tributos-, será suficiente acreditar que se ha realizado "un intento» de notificación que contenga el texto íntegro de la resolución» ${ }^{155}$.

En modo alguno podemos entender que el inciso «a efectos de entender cumplida la obligación .... y de computar el plazo de reso-

guirán siendo otro foco de problemas, ya que no se contará como transcurso ordinario del plazo aquella circunstancia que no sea imputable ni al administrado ni a la Administración, a diferencia del sistema anterior. HERRERO DE EGAÑA Y ESPINOSA DE LOS MONTEROS, J.M. (coord.): Comentarios..., op. cit. Volumen II, pág. 1410; A efectos de entender cumplida la obligación de notificar y de computar el plazo de resolución serán aplicables las reglas contenidas en la LGT art. 104.2, que establece que a los solos efectos de entender cumplida la obligación de notificar dentro del plazo máximo de duración de los procedimientos, será suficiente acreditar que se ha realizado un intento de notificación que contenga el texto íntegro de la resolución y, además, que los períodos de interrupción justificada que se especifiquen reglamentariamente (supuestos de delito contra la hacienda pública tipificado en el CP art. 305) y las dilaciones en el procedimiento por causa no imputable a la Administración Tributaria no se incluirán en el cómputo del plazo de resolución. AA.VV. (coord. PELÁEZ MARTOS, J.M. ${ }^{a}$ ): Todo procedimiento..., op. cit., pág. 1177.

${ }_{155}$ Una de las notas características de la caducidad es la de que no se interrumpe el cómputo de su plazo sino que se suspende. Por ello, pese a que la LGT art. 104.2 habla de considerar interrumpido el plazo por dilaciones en la tramitación imputables a los contribuyentes, debe ser entendido en el sentido que se entenderá suspendido el plazo hasta que cese la causa obstativa. BAYONA JIMÉNEZ, J.J.: La caducidad..., op. cit., pág. 161; GARCÍA CALVENTE considera un error la previsión de la LGT art. 104.2, pues las notificaciones son un requisito para la eficacia de los actos, pero siempre y cuando se consideren válidas, para lo cual deberán cumplir con todos los requisitos previstos en el ordenamiento jurídico y en especial con los relativos a su práctica. Resulta evidente que con este precepto se ha intentado garantizar la agilidad de los procedimientos tributarios, pero con ello se merman las garantías que asisten a los contribuyentes. AA.VV. CALVO ORTEGA, R. (dir.), TEJERIZO LOPEZ, J.M. (coord..): Los nuevos reglamentos tributarios..., op. cit., págs. 218 y 219; la LGT equipara cualquier intento de notificación, lo que no es fácil aceptar sin críticas, aunque parezca haberlo aceptado el TS 17-11-03 que afirma que «bastará para entender concluso un procedimiento administrativo dentro del plazo máximo que la ley le asigne...el intento de notificación por cualquier medio legalmente admisible... y que se practique con todas las garantías legales aunque resulte frustrado finalmente, y siempre que quede debida constancia del mismo en el expediente. GARCÍA GÓMEZ DE MERCADO, F.: «El procedimiento sancionador en materia tributaria», en obra colectiva de VV.AA. La Nueva Ley General Tributaria, IEF, Madrid, 2004, pág. 877; Exigiendo que la notificación se haya intentado sin éxito, y sin culpa de la Administración es el TS 12-12-07; Entendemos que esta aplicación subsidiaria de la LGT art.104.2 es, a esos solos efectos, toda vez que, como hemos razonado anteriormente, las reglas de la LGT art.104 no son de aplicación supletoria en el procedimiento sancionador. DE JUAN CASADEVALL, J.: «La caducidad...», op. cit., QF, núm. 12, 2005; En todo caso, recordar que el TC 139-04 considera una garantía esencial al infractor la notificación penal de la sanción. CALDERÓN GONZÂLEZ, J.M.: «El procedimiento sancionador...», op. cit.

(C) UNED. Revista de Derecho UNED, núm. 23, 2018 
lución serán aplicables las reglas contenidas en el apartado 2 del artículo 104 de esta ley » (LGT art. 211.2), no nos debe llevar al error de entender que se remite a la LGT art. 104.2. ${ }^{a}$ segundo párrafo, que ciertamente trata sobre los supuestos de interrupción justificada que no se incluirán en el cómputo del plazo de resolución, pues realmente, si bien el precepto parece que apunta en ese sentido, realmente la LGT art. 211.2 únicamente pretende interrumpir el plazo de caducidad con un intento de notificación, y no aplicando la totalidad de los supuestos de interrupción justificada que se establecen, ya no legalmente, sino reglamentariamente. Éstos últimos preceptos se refieren a actuaciones que solamente tienen cabida en procedimientos de aplicación de los tributos, más no en sancionadores, salvo la del RGGI art. 103.1.b), cuya aplicación tampoco procedería, por referirse ese precepto a normas sobre aplicación de los tributos, cuando el procedimiento sancionador ya tiene su propia regla en la suspensión de la LGT art. 180.1, que resulta aplicable tanto a la caducidad como a la prescripción.

En cualquier caso, este precepto sólo pretende corroborar que dicho plazo no se entiende incumplido cuando se ha intentado la notificación al menos una vez, pero no atribuye efectos interruptivos al intento de notificación, pues, sólo el acto de notificación válidamente practicado interrumpe la prescripción ${ }^{156}$.

El contenido necesario resolutivo ${ }^{157}$ se puede encontrar en la LPAC art. 88.3, con lo que «las resoluciones contendrán la decisión, que será motivada ${ }^{158}$ en los casos a que se refiere el artículo 35. Expresarán, además, los recursos que contra la misma procedan, órgano administrativo o judicial ante el que hubieran de presentarse y plazo para interponerlos, sin perjuicio de que los interesados puedan ejercitar cualquier otro que estimen oportuno» ${ }^{159}$.

156 MARTÍNEZ LAFUENTE, A. (dir.) et alii: Estudios sobre la nueva Ley General Tributaria. Homenaje a D. Pedro Luís Serrera Contreras, MEH, IEF, Madrid, 2004, pág. 400.

157 Específicamente exige que el acto sea notificado o se entienda notificado, conforme a la LGT art.109 a 112, sin perjuicio de que, supletoriamente, se apliquen las disposiciones generales sobre los procedimientos administrativos (LGT art. 97.b), y que el régimen de notificaciones sea el previsto en las normas administrativas generales con las especialidades establecidas en la sección $3 .^{\text {a }}$ del capítulo II del título III de la Ley General Tributaria (LGT art. 109).

${ }_{158}$ También exige motivación, como no podría ser de otro modo, el RSAN art. 24.1, motivación que no puede ser suplida por referencias a preceptos legales. ANÍBARRO PÉREZ, S. y SESMA SÁNCHEZ, B.: Infracciones..., op. cit., pág. 241.

159 Por remisión de la LGT art.109 debemos estar, para el plazo de las notificaciones y notificaciones con contenido defectuoso o incompleto, al tenor de la LPAC art. 40.3, cuando norma que «las notificaciones que conteniendo el texto íntegro 
Debemos precisar el significado de la expresión «un intento de notificación» ${ }^{160}$ de la LGT art. 104.2, poniéndolo en relación con el párrafo primero y segundo de la LGT art. $112.1 .^{\circ}$, que concreta «cuando no sea posible efectuar la notificación al interesado o a su representante por causas no imputables a la Administración tributaria $e$ «intentada al menos dos veces» en el domicilio fiscal, o en el designado por el interesado si se trata de un procedimiento iniciado a solicitud del mismo, se harán constar en el expediente las circunstancias de los intentos de notificación. Será suficiente «un solo intento» cuando el destinatario conste como desconocido en dicho domicilio o lugar. En este supuesto se citará al interesado o a su representante para ser notificados por comparecencia por medio de anuncios que se publicarán, por una sola vez para cada interesado...». Dicha redacción pudiera hacer pensar que el legislador ha tratado de separar el vocablo "intento», del "número de veces» que se ha tratado de practicar la notificación, sin embargo un intento comporta una vez o práctica ejecutoria de la notificación. Así basta que se haya practicado una vez la notificación, esto es, se haya realizado un intento, para que se entienda cumplida la obligación de notificar dentro del plazo máximo del procedimiento, lo que no significa que se haya notificado, ni tampoco manifiesta en qué plazo subsiguiente, también, máximo, deba efectuarse definitivamente la notificación de las actuaciones. Sin embargo, debemos expresar que habrá que estarse al modo de notificar regulado en la LGT art. 112 y el RGGI arts. 114 y 115, así como, subsidiariamente, $\mathrm{y}$, en lo que no resulte contradictorio con las especialidades de dichos preceptos, por lo previsto en la LPAC art. $39^{161}$ a 46 y disp. adic $1 .^{\mathrm{a}} .2 .^{\circ}$ y a la L 43/2010 art.14, 16, 17, 22.4..$^{\circ}$ y 23 y al RD 1829/1999 arts. 39 a 44 que desarrollan lo establecido en la L 24/1998 del Servicio Postal Universal y de Liberalización de los

del acto omitiesen alguno de los demás requisitos previstos en el apartado anterior surtirán efecto a partir de la fecha en que el interesado realice actuaciones que supongan el conocimiento del contenido y alcance de la resolución o acto objeto de la notificación o resolución, o interponga cualquier recurso que proceda $\left(3 .^{\circ}\right)$. Sin perjuicio de lo establecido en el apartado anterior, y a los solos efectos de entender cumplida la obligación de notificar dentro del plazo máximo de duración de los procedimientos, será suficiente la notificación que contenga cuando menos el texto íntegro de la resolución, así como el intento de notificación debidamente acreditado $\left(4 .^{\circ}\right) »$. Este precepto no resulta en modo alguno incompatible con lo dispuesto en la Ley General Tributaria, que resulta válido incluso para el procedimiento inspector tramitado de manera separada al sancionador.

160 Así el TS 17-11-03.

161 LPAC art. 40.2: "Toda notificación deberá ser cursada dentro del plazo de diez días a partir de la fecha en que el acto haya sido dictado...».

(C) UNED. Revista de Derecho UNED, núm. 23, 2018 
Servicios Postales ${ }^{162}$, con la regulación especial de las actas con conformidad contempladas en la LGT art. 211.1. ${ }^{\mathrm{a}}$.1.

\section{EFECTOS DE LA CADUCIDAD}

Transcurrido el plazo fatal de la caducidad en su iniciación tendrá efectos obstativos para el ejercicio de la potestad sancionadora, en palabras de ESEVERRI ${ }^{163}$, no se podrá ya abrir el expediente sancionador al referido obligado tributario por la presunta infracción derivada de aquel procedimiento de comprobación o investigación, de manera que, la Administración, desde que obtuvo la notitia criminis, como quiera que dispone de los datos suficientes para iniciar el procedimiento sancionador dentro de dicho plazo, si no lo lleva a efecto, sólo puede deberse a un desinterés manifiesto en el ejercicio de la potestad sancionadora, o a la simple desidia para su puesta en práctica [desinterés o desidia que desde nuestro punto de vista no justifica la naturaleza jurídica de la caducidad], actitudes administrativas que, ni deben, ni pueden ser primadas reavivando otra oportunidad para el ejercicio de la potestad sancionadora a quien, pudiendo hacerlo, no puso en funcionamiento sus mecanismos correspondientes. La caducidad del ejercicio de la potestad sancionadora de la Administración tributaria contemplada en el artículo 209.2 de la LGT se configura como una figura extintivo-temporal de efectos jurídicos sustantivos o materiales, al cercenar la concreta actuación de la potestad sobre la cual se proyecta. Dicho en términos más explícitos, vencido el plazo máximo trimestral de que dispone la Administración tributaria para la incoación del procedimiento sancionador tributario, decae la posibilidad de que aquélla

162 Téngase en cuenta que quedan derogados cuantos preceptos de esta norma contradigan lo dispuesto en el RD 1298/2006, de 10 de noviembre, según establece su disposición derogatoria única.

${ }^{163} \mathrm{He}$ dicho que ese plazo rige para proceder al inicio de cualquier procedimiento de gestión e inspección tributaria, mas, ello no es exacto del todo en lo concerniente a los procedimientos de gestión, porque literalmente, el art. 209.2 LGT al referirse a ellos alude exclusivamente, al iniciado mediante declaración, al de verificación de datos y a los de comprobación (entre los que se incluye el de comprobación limitada), pero no se hacer referencia al procedimiento de gestión que se inicia en solicitud de devoluciones tributarias porque, a través de ellos, o bien se atiende a la pretensión de devolución del obligado tributario, en cuyo caso no hay razón para la apertura de procedimiento sancionador; o bien, la petición de devolución desemboca en la apertura de otro procedimiento para la aplicación del tributos (de verificación de datos, de comprobación limitada, incluso, de inspección tributaria), supuesto en el que al hilo del procedimiento de aplicación del tributo que se desarrolle será oportuna la notificación de inicio del procedimiento sancionador que pudiera derivarse de las actuaciones comprobadas. ESEVERRI..., 2011, 463. 
pueda actuar su ius puniendi y, por ende, sancionar válidamente la infracción tributaria, aún cuando la responsabilidad, que de su comisión deriva, no haya prescrito. En conclusión, la caducidad del procedimiento para el ejercicio de la potestad sancionadora de la Administración tributaria que se anuda, como consecuencia jurídica, al transcurso del plazo, supone, terminantemente, que el ilícito tributario no pueda ser sancionado.

Una consecuencia más interesante de esta regla, para Almenar Berenguer y Ripley Soria ${ }^{164}$, es que, en caso de anulación de una sanción en vía administrativa o judicial, se reanudará el cómputo del tiempo restante para la incoación de nuevo procedimiento sancionador, si como consecuencia de la resolución debe iniciarse un nuevo procedimiento sancionador.

La orientación jurídica del Tribunal supremo en la materia se decanta por la inteligencia de que la caducidad del procedimiento sancionador arrastra la nulidad de la resolución dictada en su seno de manera extemporánea, ya que la caducidad — que debe apreciarse y acordarse de oficio por el propio órgano competente para dictar la resolución- ocasiona inevitablemente el archivo de lo actuado. La STS de 28 de junio de 2004, es contundente cuando afirmó que «sin género de dudas, cualquier resolución dictada una vez producida la caducidad del procedimiento resulta anulable, puesto que todas las actuaciones del mismo habrían debido ser archivadas. Alguna sentencia ${ }^{165}$ incluso sostiene que no se trata de un supuesto de anulabilidad, sino de nulidad de pleno derecho, por basarse la resolución sancionadora en un procedimiento inválido e ineficaz en la medida en que el mismo por haberse producido la caducidad, debió archivarse en su momento.

La caducidad, en cuanto limitación del poder administrativo, al igual que la prescripción es necesariamente aplicable de oficio, de modo que no es necesario que se haya alegado en vía administrativa para posteriormente invocarla en vía jurisdiccional. En cualquier caso, supone una obligación, tanto de la Administración, como de los Tribunales de Justicia, el apreciar su concurrencia, y su omisión o incumplimiento constituye una posible causa de impugnación de los actos administrativos o de las decisiones judiciales ${ }^{166}$. En caso de que no resultare aplicada por la Administración, ordenando su archivo, el interesado podrá oponerse formalmente a los actos de de-

${ }^{164}$ HERRERO DE EGAÑA Y ESPINOSA DE LOS MONTEROS, J.M. (coord.): Comentarios..., op. cit., vol. II, pág. 1401.

165 STSJ Castilla y León-Valladolid, de 28.04.2000.

166 AGUADO I CUDOLÀ, V.: La prescripción ..., op. cit., pág. 28. 
sarrollo que se sigan, en cuyo caso la Administración podrá contestar de modo favorable - en cuyo caso ahí termina el procedimiento sancionador- o bien contestar de modo desfavorable o simplemente no contestar, cuyo caso Morillo Méndez ${ }^{167}$ entiende que cabrá recurso.

El plazo de notificación de la iniciación del procedimiento sancionador sólo se dirige al obligado tributario que haya sido objeto del correspondiente procedimiento de gestión o de inspección tributaria, no resultando aplicable la caducidad producida a un tercero que como consecuencia de esos procedimientos deba ser calificado como sujeto infractor mediante la imputación de alguno de los ilícitos tributarios $^{168}$.

La caducidad en la terminación comportará ${ }^{169}$ el archivo de las actuaciones producidas y la imposibilidad de volver a ini-

167 MORILLO MÉNDEZ, A.: «Caducidad...», 117.

168 Así en el caso de resistencia u obstrucción a la actuación comprobadora (art. 203 LGT) es conducta infractora que deba imputarse a quien realmente entorpezca el desarrollo de tales actuaciones, si quien la lleva a cabo es el representante del obligado tributario en un procedimiento de aplicación de los tributos, como no es la persona objeto de dicho procedimiento, no existe el deber de notificar el inicio de incoación de expediente sancionador en el plazo de tres meses, bajo amenaza de preclusión del mismo, sino que el órgano sancionador dispone de los cuatro años de prescripción de la acción sancionadora para iniciar un procedimiento de esa naturaleza. ESEVERRI..., 2011, op. cit., pág. 464.

169 ANÍBARRO PEREZ, S. y SESMA SÁNCHEZ, B.: Infracciones..., op. cit., pág. 223; la caducidad no conlleva per se la consumación de la potestad propiamente considerada, sino exclusivamente la pérdida de su potencial ejercicio en un supuesto determinado. MAGRANER MORENO, F.J. y MARTÍN LÓPEZ. J.: «El límite temporal...», op. cit., $Q F$, núm. 20, 2003, pág. 10; La caducidad, siendo ésta una forma de extinción del procedimiento y caracterizándose a través de sus propios efectos, se puede afirmar que la misma produce la desaparición del mundo jurídico del procedimiento caducado. Ello, al menos en principio, no debiera impedir una nueva iniciación del procedimiento sancionador - que sería el primero y único existente- . La solución que plantea la nueva norma no facilita la diferenciación entre los institutos de la prescripción y de la caducidad. Impedir iniciar un nuevo procedimiento sancionador tras y por causa de la caducidad de uno previo por inactividad de la Administración equivaldría a entender extinguida la acción para imponer sanciones a través del procedimiento sancionador. Se crea por lo tanto una confusión entre ambos institutos jurídicos, que como hemos manifestado, protegen diferentes agresiones a la seguridad jurídica 66. Otra cuestión es que la existencia de un plazo máximo para iniciar el procedimiento sancionador en ciertos casos, suponga - tras el transcurso de seis meses y la caducidad del procedimiento sancionador - la imposibilidad de iniciar un nuevo procedimiento sancionador siendo precisamente aquel plazo máximo del art. 209.2 de la nueva LGT la causa de ello. Quizás fuera una opción — con la finalidad de evitar la confusión entre caducidad y prescripción- excepcionar la aplicación de ese plazo máximo para iniciar el procedimiento sancionador en los casos de caducidad de aquél iniciado en plazo, a los efectos de poder iniciar otro nuevo. Las razones para impedir 
$\operatorname{ciar}^{170}$ otro procedimiento sancionador por los mismos hechos, lo que no obstará la viabilidad de iniciar un nuevo procedimiento de comprobación cuando, al amparo de los artículos 101.3 o 140 de la LGT, se descubran nuevos hechos o circunstancias que resulten de actuaciones distintas de las realizadas y especificadas en el primer procedimiento sancionador, y como consecuencia de él se impongan las correspondientes sanciones ${ }^{171}$. La caducidad del procedimiento sancionador tributario prevista en los artículos 211.4 de la LGT genera la extinción del propio procedimiento, impidiendo exigir la responsabilidad dimanante de la comisión de la infracción tributaria aunque no hubiera prescrito, pues sin procedimiento sancionador no existe sanción posible ${ }^{172}$. En cualquier caso, la caducidad deja sin resolver el fondo del asunto ${ }^{173}$.

Un aspecto relevante para el análisis de los efectos jurídicos de la caducidad es la posibilidad de que la declaración por la que se ordena el archivo de las actuaciones se adopte a instancia de parte. Esta singular habilitación legal obliga a interrogarse acerca de la respuesta que la Administración debe dar cuando se le dirige una solicitud que tiene por objeto obtener una declaración de caducidad. A

la iniciación de un nuevo procedimiento sancionador tras la caducidad de uno anterior podrían provenir - aun cuando no las compartimos- de la posible vulneración del principio non bis in ídem. Y el mismo podría justificar la prohibición de iniciar un nuevo procedimiento sancionador... En todo caso, no nos convence plenamente esa solución pues la aplicación del mencionado principio del orden sancionador lo que impide es ser juzgado y sancionado en más de una ocasión. MARTÍNEZ GINER, L.A.: «La caducidad de los procedimientos tributarios en la nueva Ley General Tributaria», QF, núm. 11, 2004.

${ }^{170}$ No obstante, el tenor literal del artículo 211.4 de la Ley 58/2003, General Tributaria es algo impreciso y pudiera dar lugar a cierta confusión. En efecto, la caducidad no impide en sí misma la iniciación de un nuevo procedimiento sancionador, tal y como parece desprenderse del precepto señalado. Lo que la impediría sería el incumplimiento de la previsión del artículo 209.2 de la nueva LGT, es decir, el transcurso del plazo de tres meses desde la notificación de la liquidación de la cual deriva el expediente sancionador. En definitiva, la caducidad del procedimiento no puede impedir por sí sola la iniciación de uno nuevo. MARTÍNEZ GINER, L.A.: «La caducidad...», op. cit.; en el art. 31.3 del Proyecto de Reglamento General del Régimen Sancionador Tributario se disponía que la iniciación del procedimiento de imposición de las sanciones no pecuniarias se realizará, en su caso, una vez que haya adquirido firmeza en vía administrativa la resolución del procedimiento sancionador del que se derive. En el texto definitivamente aprobado no figura esta disposición. AA.VV. (coord. PELÁEZ MARTOS, J.M. ${ }^{\mathrm{a}}$ ): Todo procedimiento Tributario 20072008, CISS, Valencia, 2007, pág. 1168.

171 ANÍBARRO PÉREZ, S. y SESMA SÁNCHEZ, B.: Infracciones..., op. cit., pág. 223.

172 SÁNCHEZ HUETE, M.A.: «Una visión crítica del sistema sancionador de la LGT», JT, 2006, BIB 2006\327.

173 MORILLO MÉNDEZ, A.: «Caducidad ...», op. cit., pág. 118. 
nuestro modo de ver, las alternativas a contemplar son las siguientes: i) adopción de la declaración de caducidad; ii) denegación expresa de la solicitud y continuación de las actuaciones; iii) denegación tácita de la solicitud y continuación de las actuaciones. En el primer caso es evidente que estamos ante un acto resolutorio respecto a la existencia de caducidad, pero «de trámite» respecto al objeto del procedimiento sancionador - que es determinar si existe o no existe responsabilidad infractora-, por el que se acuerda el archivo de las actuaciones y cuyos efectos jurídicos ya han sido objeto de análisis en los apartados anteriores. En cualquier caso, dicho acto debe notificarse al interesado. En el segundo caso, estamos ante un acto expreso por el que se deniega la solicitud que tiene por objeto obtener una declaración de caducidad. Por ello la cuestión principal a resolver es determinar su régimen de impugnación o, lo que es lo mismo, establecer si contra dicha denegación cabe interponer recurso o, por el contrario, alegar dicha circunstancia al impugnar el acto de imposición de la sanción. Ante el silencio de la norma, nos inclinamos por atribuir a la solicitud de caducidad naturaleza incidental. Luego, ni suspende el procedimiento ni su eventual denegación es susceptible de recurso separado, puesto que no decide directa ni indirectamente el fondo del asunto, ni pone fin al procedimiento sancionador (art. 227.1 b LGT). Es decir, si existen circunstancias que afectan al cómputo del plazo de caducidad, la Administración puede valorar su concurrencia y entender que dicho efecto no se ha producido, comunicando dicha circunstancia al interesado. Naturalmente, una vez notificado el acto de imposición, el incumplimiento del plazo para resolver podrá invocarse como un vicio formal, cuestión que se decidirá por el órgano administrativo o judicial que conozca del recurso interpuesto contra la sanción. Finalmente, si en lugar de denegar, la Administración se limita a dictar y notificar el acuerdo de imposición de la sanción, es evidente que el único cauce para que se reconozcan los efectos jurídicos de la caducidad es la impugnación de la resolución sancionadora supuestamente adoptada fuera de plazo.

Por último, Martínez Lago ${ }^{174}$ opina que los efectos derivados del plazo máximo de duración de los procedimientos para imposición de sanciones y para derivación de responsabilidad (art. 124.1.4. ${ }^{\circ}$ RGR) son evidentes. Aunque ambos procedimientos tienen atribuido el mismo plazo de duración, en el marco del procedimiento sancionador, la caducidad dará lugar a la imposibilidad de iniciar

174 MARTÍNEZ LAGO, M.A. La extensión de la responsabilidad a las sanciones tributarias, Tirant lo Blanch, Valencia, 2008, pág. 413. 
de nuevo el procedimiento frente al presunto infractor, lo que no sucederá en el procedimiento de declaración de responsabilidad, pese a que si la misma se extiende a las sanciones, por tener éstas naturaleza punitiva, debería implicar los mismos efectos que la omisión de resolución expresa general en el procedimiento sancionador tributario.

\section{CONCLUSIONES}

No podemos terminar el presente artículo sin incluir unas escuetas conclusiones sobre la caducidad en la iniciación del procedimiento sancionador tributario que reflejen aquellas ideas principales, al menos desde nuestro punto de vista, y que son:

1. La caducidad en el procedimiento sancionador tributario es una institución jurídica que sirve y protege la seguridad jurídica ante la existencia de un procedimiento pendiente, compatible con el instituto de la prescripción, cuyo fin último es poner límite al ejercicio de las facultades que emanan de la potestad administrativa sancionadora.

2. Defendemos, frente a otras posturas, la naturaleza del plazo de caducidad inicial que fija Ley General Tributaria como la de un plazo de caducidad del ejercicio de la potestad sancionadora.

3. Resulta de trascendental importancia el transcurso de un plazo de tiempo - de tres meses-, legalmente establecido en el art. 209.2 LGT, sin que se haya producido la notificación -o cuando se entienda notificada - de una determinada actuación administrativa incoatoria por parte del órgano competente en materia sancionadora tributaria, y ello con independencia de que exista una voluntad procedimental de la Administración dirigida a la realización o ejercicio de la concreta potestad administrativa sancionadora.

4. El artículo 209.2 de la LGT ha introducido una auténtica limitación temporal para la iniciación del procedimiento sancionador, que únicamente operará en los casos en los que se incoe como consecuencia de un procedimiento iniciado mediante declaración del contribuyente o de un procedimiento de verificación de datos, comprobación o inspección.

5. Por prudencia, defendemos la conveniencia - que no obligación- de la sucesión temporal entre el procedimiento de apli- 
cación de los tributos y el, posterior, sancionador, ya que si durante las actuaciones de aplicación de tributos se manifestasen posibles infracciones tributarias, que no pudieren constatarse hasta la resolución final de aquel procedimiento, resultaría más factible que el procedimiento sancionador se iniciase una vez finalizada la tramitación de las actuaciones de aplicación de los tributos.

6. El dies a quo del plazo de caducidad, con carácter general, será la fecha de la notificación del acuerdo de incoación el que determine el inicio del cómputo de la caducidad.

7. Lamentamos que legal y reglamentariamente no se haya dado acceso, como interesado, al presunto responsable [tributario] en el momento de incoar procedimiento para imponer la sanción tributaria.

8. Si bien hemos defendido la ininterrumpibilidad del plazo trimestral de incoación de los procedimientos sancionadores tributarios prevista en el artículo 209.2 de la LGT, admitimos la suspensión de su cómputo, en el no tan inhabitual caso de que, finalizado uno de los procedimientos a que refiere el precepto, y con carácter previo al inicio del oportuno expediente sancionador, la Administración tributaria apreciase indicios de delito contra la Hacienda Pública.

9. Transcurrido el plazo fatal de la caducidad en su iniciación tendrá efectos obstativos para el ejercicio de la potestad sancionadora, de modo que no se podrá ya abrir el expediente sancionador al referido obligado tributario por la presunta infracción derivada de aquel procedimiento de aplicación de los tributos. 